Pace University

DigitalCommons@Pace

\title{
The Egyptian Coup, the United States, and a Call to Strengthen the Rule of Law and Diplomacy Rather Than Military Counter- Terrorism
}

Thomas McDonnell

Elisabeth Haub School of Law at Pace University

Follow this and additional works at: https://digitalcommons.pace.edu/lawfaculty

Part of the Comparative and Foreign Law Commons, International Law Commons, Military, War, and Peace Commons, and the National Security Law Commons

\section{Recommended Citation}

Thomas Michael McDonnell, The Egyptian Coup, the United States, and a Call to Strengthen the Rule of Law and Diplomacy Rather Than Military Counter-Terrorism, 41 N.C. J. Int'I L. 325 (2016),

http://digitalcommons.pace.edu/lawfaculty/1020/.

This Article is brought to you for free and open access by the School of Law at DigitalCommons@Pace. It has been accepted for inclusion in Pace Law Faculty Publications by an authorized administrator of DigitalCommons@Pace. For more information, please contact dheller2@law.pace.edu. 


\title{
The Egyptian Coup, the United States, and a Call to Strengthen the Rule of Law and Diplomacy Rather Than Military Counter-Terrorism
}

\author{
By Thomas Michael McDonnell†
}

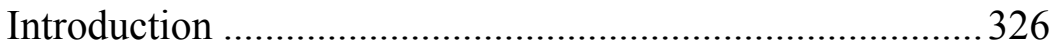

I. Conquest and Colonization of Egypt........................ 328

A. Early History ................................................... 328

B. The Rise of Nasser - the Secular, Authoritarian Military Leader ................................................. 335

C. The Rise of al-Banna and the Muslim Brotherhood 340

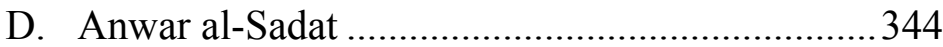

II. The United States, Egypt, and the Middle East......... 347

A. The United States Assumes the Mantle of a Colonial Power.

B. The Perceived Communist Threat

III. The Arab Spring, the Military Coup d'État, and the Following Repression

A. The Disappointing Outcome of the Arab Spring 351

B. Hosni Mubarak, His Human Rights Violations, and the United States 352

C. The Egyptian Elections Stemming From the Arab Spring 355

D. The "Judicial Coup" and Human Rights Violations Committed under SCAF 358

\footnotetext{
† Professor of Law, Pace University School of Law

For reviewing a draft of this Article, I wish to thank Professor Sahar Aziz from Texas A\&M University School of Law, Professor Adele Bernard from New York Law School, Professor Lissa Griffin from Pace University School of Law, and Professors Linda Edwards and Michael Kagan from the University of Nevada School of Law. I also wish to thank Pace Law librarians Vicki Gannon, Lucie Olejnikova, and Cynthia Pittson; my assistant, Lorraine Rubich; and my research assistants: Rocky Boussias, Monica Craig, Lauren Fitton, Alexia Mickles, and Kara Paulsen. I thank my wife Kathryn, whose support made this Article possible. I dedicate this Article to my aunts, Sister Marie Irene (Antoinette Scarola), S.S.N.D, and Dr. Mary I. Scarola.
} 
E. Human Rights Violations under the Morsi Administration

F. The Military Coup, the Military's Repression of the Muslim Brotherhood, and the U.S. Response.....365

IV. International Law As a Guide to Counter-Terrorism

Policy and Practice 375

A. The Emerging Norm Prohibiting Military Overthrow of Democratic Governments. 375

B. Human Rights Law and the Aftermath of the Military Coup.

C. International Law, Colonization, Annexation, Discrimination, and the West..... 385

V. United States Flawed Response to the Coup d'État ..392 Conclusion

\section{Introduction}

The increasing number of barbaric attacks carried out by the Islamic State of Iraq and Syria ("ISIS") against the innocent, and its resulting war crimes, genocide, and crimes against humanity must be addressed by the international community. ${ }^{1}$ But another series of horrific events in arguably the most important Arab countryEgypt - also require international attention and call into question the United States' and the West's policies and practices in the Middle East and in the Islamic world generally. ${ }^{2}$ By refusing to cut off military aid to the Egyptian military regime after it overthrew its first fairly elected President in $2013^{3}$ and by continuing massive

\footnotetext{
1 How ISIS Crippled al-Qaida, GUARDIAN (June 10, 2014), http://www.theguardian.com/world/2015/jun/10/how-isis-crippled-al-qaida [http:// perma.cc/S8QL-5XVL]; see, e.g., Osama Bin Laden Considered ISIS Too Brutal and Advised al Qaeda Cadres to Sever Ties with It, SAMAY Live (India) (Aug. 12, 2014), http://www.saharasamay.com/world-news/676558706/osama-bin-laden-considered-isis-t oo-brutal-and-advised-al-qaeda-.html [http://perma.cc/W4YH-GY72] (discussing al Qaeda's disproval of ISIS's extremism); Tom McDonnell, Questions on President Obama's Strategy Against ISIS, HILL (Sept. 17, 2014), http://thehill.com/blogs/congressblog/homeland-security/217888-questions-on-president-obamas-strategy-against-isis [http://perma.cc/6REG-RCTA] (describing the causes for the rise of ISIS).

2 See Patrick Kingsley \& Marin Chulov, Mohamed Morsi Ousted in Egypt's Second Revolution in Two Years, GuARDIAN (July 4, 2013), http://www.theguardian.com/world/ 2013/jul/03/mohamed-morsi-egypt-second-revolution [http://perma.cc/SMS6-Q8S8].

3 Id.
} 
military aid $^{4}$ despite the regime's violent repression of mostly peaceful Muslim Brotherhood protesters, the United States demonstrates that its leaders have still failed to recognize the likely origin of September 11.

A better understanding of the causes underlying terrorist violence against the United States may help policy makers resort less to military force and more to peaceful, diplomatic approaches. ${ }^{5}$ A fairly detailed recounting of the history of Egypt, particularly its interface with the West, is required to gain a firmer grasp of the challenge that confronts the West generally and the United States in particular. The history of Egypt's interaction with the West is emblematic of the West's interaction with Islam. What, unfortunately, is usually left out of Western discussions of Islamic terrorism is that nearly every Muslim country was colonized by Russia $^{6}$ or Western European nations. ${ }^{7}$ This colonization had, among others, the perverse effects both of thrusting autocratic military leaders into power and of galvanizing extremist exponents of Islam. Following colonization, other repressive secular rulers arose in Islamic countries including Egypt, leaders who likewise sparked an extremist reaction from Islam's fundamentalist strain. ${ }^{8}$ In general, the United States and other Western countries have supported these authoritarian secular leaders. The Arab Spring attempted to create a third way, but largely fell victim to entrenched

4 See id.

5 See Audrey Kurth Cronin, How Terrorism Ends: Understanding the DeCLINE AND DEMISE OF TERRORIST CAMPAigns 11 (2009) ("State use of brute force has a long history: at some point in the last two centuries, countries in every part of the worldfrom Britain to China, Peru to Pakistan, and France to the Philippines-have tried to use force to stamp out terrorism at home or abroad, usually unsuccessfully.").

6 See William W. Cooper \& Piyu Yue, Challenges of the Muslim World: Present, Future And Past 228 (2008) (showing Russia colonized six Muslim South Asian countries: Azerbaijan, Kazakhstan, Kyrgyzstan, Tajikistan, Turkmenistan, and Uzbekistan); S.V.R. Nasr, European Colonialism and the Emergence of Modern NationStates, in ThE OXFORD History OF ISLAM 551, 551 (John L. Esposito ed., 1999), http://www.oxfordislamicstudies.com/article/book/islam-9780195107999/islam-9780195 107999-chapter-13 [http://perma.cc/V5KZ-SZ3R] (discussing Russia's continuing sovereignty over the historically Muslim region of Chechnya).

7 Thomas Michael McDonnell, The United States, International Law, and THE StrugGle AgAinst Terrorism 19-27 (2011) (listing Islamic countries colonized by Western European nations).

8 See Jane F. Collier, Islamic Law and Western Imperialism, StAn. ElECTRONIC HuMAN. REV. (Feb. 15, 1996) (book review), http://web.stanford.edu/group/SHR/51/text/collier.html [http://perma.cc/53MU-5NEJ]. 
repressive military forces. ${ }^{9}$

Faced with the threat of extremist violence, the United States and its allies may, however, draw upon revolutionary developments in international law since the end of World War II to help fashion a sounder counter-terrorism policy and practice. Part I of this article examines the troubling history of Egypt's encounter with the West. Part II discusses United States' approach to Egypt and to the Middle East generally. Part III reviews the Arab Spring, the Egyptian coup, and its aftermath. Part IV analyzes international law prohibiting coups d'état, political repression, colonization, conquest, and systematic racial and religious discrimination. Lastly, Part V critiques the United States' response to the coup and argues that Western states and Russia have a moral, if not absolutely legal, obligation both (a) to make reparation to all the peoples in the Middle East, and to the Islamic world generally and (b) to foster the rule of law, human rights, and democratic institutions in all those states. An effective and principled counter-terrorism policy and practice require no less. ${ }^{10}$

\section{Conquest and Colonization of Egypt}

\section{A. Early History}

Egypt had been a Muslim country since $641 \mathrm{CE} .{ }^{11}$ The army of Sultan Selim brought Egypt into the Ottoman Empire after defeating the ruling Mamluks outside Cairo in 1517. ${ }^{12}$ In 1798, Egypt, however, was conquered by Napoleon. ${ }^{13}$ Napoleon's conquest was short-lived; the Ottoman Turks and the British banded together and pushed the French out in $1801 .{ }^{14}$ One of the Turkish officers,

9 See Ronald Bailey, Why Arab Democracy Will Fail, REASON.COM (Aug. 23, 2013), http://reason.com/archives/2013/08/23/why-arab-democracy-will-fail [http://perma.cc/ NTR4-ENBZ].

10 Much of the material for Part I of this article is drawn from my book, MCDONNELL, supra note 7, at 4-14.

11 Walter E. Kaegi, Egypt on the Eve of the Muslim Conquest, in 1 THE CAMBridge History of Egypt 34, 61 (Carl F. Petry ed., 1998); see also StANFORd J. SHAw, History OF THE OtTOMAN EMPIRE AND MODERN TURKEY 152 (1976).

12 Emory C. Bogle, Islam: Origin and Belief 68 (1998); see also Caroline Finkel, OSMAN's Dream: The STORy OF THE OtTOMAN EMPIRE 1300-1923, at 110 (2005).

13 See Dan E. Stigall, Iraqi Civil Law: Its Sources, Substance, and Surrendering, 16 J. TRANSNAT'L L. \& POL'y 1, 9 (2006).

14 Id. 
Muhammad Ali (also known as Mehemet Ali), became the ruler of Egypt. ${ }^{15}$ He defeated the British in 1807, brutally confiscated the lands of rival feudal lords, persuaded the Ottoman Sultan to name him viceroy, and, of all Muslim leaders in the nineteenth century, did the most to modernize his adopted country along European lines. ${ }^{16}$ He ruthlessly impressed the peasantry into the army and into his textile mills. ${ }^{17}$ He also excluded the Muslim clergy, the ulama, from avenues of power. ${ }^{18}$

Muhammad Ali gained Egypt's de facto independence from the Ottoman Empire, an independence that displeased Britain. ${ }^{19}$ One of Ali's military campaigns threatened Constantinople. ${ }^{20}$ Britain and France supported the Ottoman Empire in fending off the attack and in defeating Ali. ${ }^{21}$ Under the terms of the Treaty of London of 1841, Ali had to give up Syria, limit his army to 18,000 troops, and ease his tariffs on British imports, an act that contributed to the failure of his efforts to establish Egyptian manufacturing. ${ }^{22}$

Said Pasha, Muhammad Ali's son, began his nine-year rule in 1854. ${ }^{23}$ Wanting to continue the modernization of Egypt, he gave

15 See id.

16 Muhammad Shafiq Ghurbal, The Beginnings of the Egyptian Question and the Rise of Mehemet Ali 280, 284 (1977); Karen Armstrong, Islam: A Short HISTORY 150-51 (2000).

17 See Kaegi, supra note 11; SHAw, supra note 11 (discussing Egypt's history as a Muslim country).

18 Arthur Goldschmidt Jr. \& Aomar Boum, A Concise History of the Middle EAST 173-74 (8th ed. 2006); JASON GOODWIn, LORDS OF THE HorizOnS: A History OF THE OTTOMAN EMPIRE 296 (2003).

19 J. Rickard, French Invasion of Egypt, 1798-1801, MiL. Hist. ENCYCLOPEDIA ON WEB (Jan. 16, 2006), http://www.historyofwar.org/articles/wars_french_egypt.html [http://perma.cc/4CKW-TZ5X].

$20 \mathrm{Id}$.

$21 \mathrm{Id}$.

22 Geoffrey Butler \& Simon Maccoby, The Development of International LAW 440 (2003). This Treaty did make Ali's heirs hereditary rulers, the only viceroys in the Ottoman Empire to have gained this privilege. Id.; see also BoGLE, supra note 12; FinKel, supra note 12; GHURBAL, supra note 16, at 284; ARMSTRONG, supra note 16; Lowell N. Lewis, The Period of Muhammad Ali, Egyptian Agric., http://egyptianagriculture.com/muhammad_ali.html [http://perma.cc/V5DC-8RV2] (last visited Nov. 12, 2015). The Treaty of London of 1841 did make Ali's heirs hereditary rulers, the only viceroys in the Ottoman Empire to have gained this privilege. BUTLER \& MACCOBY, supra.

23 Edwin de Leon, The Khedive's Egypt: The Old House of Bondage Under NEW MASTERS 98-99 (1877). 
French diplomat and engineer Ferdinand de Lesseps the concession to build the Suez Canal. ${ }^{24}$ Financed by French, Egyptian, Spanish, and neighboring countries' investors, the de Lesseps' Suez Canal Company started construction. ${ }^{25}$ Using the forced labor of thousands of Egyptian peasants, the Company completed the Canal nearly eleven years later at twice the estimated cost. ${ }^{26}$ When the Company ran into financial trouble, Said Pasha bought forty-four percent of its stock and also ran the government into debt. ${ }^{27}$

Said's successor, Ismail spent far beyond his and his country's means, nearly bankrupting Egypt and permitting it to fall largely into the hands of French and British creditors. ${ }^{28}$ In 1875, the dire financial situation virtually compelled the government to sell its shares in the Canal to Britain. ${ }^{29}$ The French and English governments urged Ismail to abdicate in favor of his son Toufik. ${ }^{30}$ When the Ottoman Sultan agreed, Ismail was deposed, and Toufik, at 27 , became the viceroy of Egypt. ${ }^{31}$

Toufik did not reign independently for long. A charismatic officer, Said Ahmed Urabi, led an army revolt in 1881 and became the military ruler of the country. ${ }^{32}$ Urabi set to work wresting internal control of Egypt from the French and the British, and called for the expulsion of foreigners. ${ }^{33}$ His policies alarmed the two

24 Id.

25 Jimmy Dunn, Suez Canal, Tour Egypt (Aug. 21, 2011), http://www.touregypt.net/featurestories/suezcanal.htm [http://perma.cc/U5MY-UET8] (discussing construction dates); see also George Barnett SMith, The LifE And ENTERPRISES OF FERDINAND DE LESSEPS 126-28 (1893) (describing how the Suez Canal was financed).

26 See Dunn, supra note 25.

27 See DE LEON, supra note 23, at 101-02.

28 Id. at 170.

29 By 1880, sixty-six percent of Egypt's revenue went to pay the foreign creditors and the tribute to the Sultan-Caliph in Constantinople. William EWART GladSTONE, The Gladstone Diaries, at lxxi (H.C.G. Matthew ed., 1990); see also JACQUES BerQue, EGYPT: IMPERIALISM AND REVOLUTION 291 (1972).

30 Amber Darr, The Khedive's Escape, EXPRESS TrIBunE (Mar. 1, 2012), http:// tribune.com.pk/story/343507/the-khedives-escape/ [http://perma.cc/M2ZQ-WPAE].

31 Id.

32 Donald Featherstone, Tel El-Kebir 1882: Wolseley's Conquest of EGypt 8-9 (1993); DE LEON, supra note 23.

33 John Springhall, Decolonization Since 1945: The Collapse of European OvERSEAS EMPIRES 88 (2001). 
European powers. ${ }^{34}$

Although initially opposed to the Canal's construction, the British considered the completed Suez Canal vital to their interests as "the highway to India." 35 Concerned that Urabi's revolt might threaten their access to the Canal, the British invaded Egypt in 1882, beat Urabi's troops with superior firepower, captured Urabi, and reinstated Toufik. ${ }^{36}$ For the next seventy-two years, the British retained de facto if not de jure control of the country. ${ }^{37}$ Specifically, the British occupied Egypt, but permitted the Egyptian viceroy to exercise nominal authority. ${ }^{38}$ At the outbreak of the First World War, the British appointed their own sultan of Egypt, establishing a protectorate that lasted until shortly after that war. ${ }^{39}$ After the protectorate ended, authority was supposedly passed to Egypt's monarchy (Ali's heir), but real power lay with the British who continued to station large troop contingents in Egypt until 1954. ${ }^{40}$

The colonization of Egypt had practical effects, for example, changing a diverse economy into a single commodity enterprise. ${ }^{41}$ Four-fifths of Egyptian cotton now went directly to

34 Library of Cong., Egypt: A Country Study 428 (Helen Chapin Metz ed., 5th ed. 1991).

35 Aside from improved communication to India, the Suez Canal opened up much more of Africa to European exploitation. See Richard Brown, European Colonial Rule in Africa, in Africa South of the SAhara 26, 26 (32d ed. 2003); Featherstone, supra note 32 .

36 See Gladstone, supra note 29, at 327. The canal, which, in the words of one commentator, had become "the highway to India." FEATHERSTONE, supra note 32, at 7. "Almost unselfconscious, because ... before occupation was decided upon Gladstone mentioned the rights 'of . . . bondholders' [holders of the Egyptian debt] as on a par with those of the Sultan, the Khedive [royal viceroy of Egypt], and the people of Egypt." GLADSTONE, supra note 29, at lxxii (Gladstone himself was a bondholder).

37 SPRINGHALL, supra note 33, at 87 (describing the British as a protectorate of Egypt during this time period).

38 A. P. Thornton, Rivalries in the Mediterranean, The Middle East, and Egypt, in 11 The New Cambridge Modern History 567, 567-92 (F. H. Hinsley ed., 1962).

39 SPRINGHALl, supra note 33, at 87; see also BERQue, supra note 29, at 263 (“"[O]n its own authority, [Great Britain] rejected Ottoman sovereignty, dismissed the Khedive, [and] imposed its Protectorate unilaterally.").

40 Springhall, supra note 33; Bernard Reich, Political Leaders of the ConTEMPORARY MidDLE EAST AND NORTH AFRICA 190-91 (1990).

41 Timothy Mitchell, Colonising Egypt 16 (1991). Muhammad Ali started the shift towards cotton as the main cash crop, but Britain took measures, largely demanding a low tariff, which prevented the growth of Egyptian industry. See BERQUE, supra note 29. 
British textile mills. ${ }^{42}$ Some aspects of European colonization were particularly humiliating to Egyptians. For example, they were blatantly discriminated against in employment contracts. ${ }^{43}$ Furthermore, under a seventeenth-century agreement between the Ottoman Sultan and the French that ultimately applied to all Europeans, the Egyptian government had no authority to apply its laws to Europeans living in Egypt. ${ }^{44}$ Known as the Capitulations, this set of laws and practices enabled the Europeans to act with impunity in committing crimes and civil wrongs. ${ }^{45}$

After the First World War, representatives of the Egyptian people contested Britain's holding onto Egypt. ${ }^{46}$ Several U.S. members of Congress and President Woodrow Wilson himself criticized colonization and specifically the British colonization of that country. ${ }^{47}$ Britain and France successfully resisted all such demands. ${ }^{48}$ Both the peace treaties between the Allies and Turkey (representing the Ottoman Empire) and the League of Nations parceled out the Empire mainly between the British and the French. ${ }^{49}$

42 Mitchell, supra note 41.

43 Ferdinand de Lesseps, The Suez Canal, Letters and Documents Descriptive OF ITS RISE AND PROGRESS IN 1854 TO 1856, at 130-31 (1876).

441 Earl of Cromer, Modern Egypt 428 (1908) (discussing how treaty engagements protect criminality and forbid any quick action against crime).

45 See FeAtherstone, supra note 32; Springhall, supra note 33, at 87-88; Brown, supra note 35; DE LEON, supra note 23 (discussing Said Ahmed Urabi's influence on Egypt); Dunn, supra note 25 (discussing Said's purchase and the cost of the canal); BERQUE, supra note 29 (discussing the debt before and after the First World War); Laurie Milner, The Suez Crisis, BBC (Mar. 3, 2011), http:/www.bbc.co.uk/history/ british/modern/suez_01.shtml [http://perma.cc/69A8-VH89] (noting that in the twentieth century the Canal also provided a shorter route to the Persian oil fields).

46 See David Fromkin, A Peace to End All Peace: The Fall of the Ottoman EMPire AND the Creation of the Modern Middle EASt 391 (1989).

47 Erez Manela, The Wilsonian Moment 40 (2007); see also President Woodrow Wilson, Address to a Joint Session of Congress on the Conditions of Peace (Jan. 8, 1918) (transcript available at www.presidency.ucsb.edu/ws/index.php?pid=65405 [http://perma.cc/R8FG-VLA9]) (“[O]ther nationalities which are now under Turkish rule should be assured an undoubted security of life and an absolutely unmolested opportunity of autonomous development.").

48 See Fromkin, supra note 46. To the consternation of Egypt's revolutionaries, however, the United States recognized the British Protectorate in 1919. MANELA, supra note 47 , at $147-48$.

49 See, e.g., Agreement Between Great Britain and France Relating to Article 34 of the Peace Treaty of July 24, 1923, Gr. Brit.-Fr., July 24, 1923, 36 L.N.T.S. 208; Treaty of 
The creation of the mandate system in the former Ottoman Empire outraged the Arab population living in many of these lands. ${ }^{50}$ Instead of freedom and self-government, the Arabs received another brand of colonial rule. ${ }^{51}$ Only Turkey had the military strength to reject the initial peace Treaty of Sèvres. ${ }^{52}$ Upon Kemal Ataturk's overthrow of the Ottoman Sultan (the Caliph) ${ }^{53}$ and his imposition of secular rule, the Allies agreed to Ataturk's demands to retract the Treaty of Sèvres, thereby expanding Turkey's borders and eliminating the new Armenian state and Kurdistan autonomy. ${ }^{54}$ In his zeal to establish a modern, democratic Turkey, Kemel Ataturk also persuaded the Turkish Parliament to abolish the Caliphate in 1924. ${ }^{55}$ Although most Muslims frequently disagreed with the Caliph and his practice of bowing to Western powers, the abolition of the religious head for Muslims was somewhat like abolishing the papacy would be for Catholics. ${ }^{56}$ The abolition caused dismay throughout the Muslim world, leaving Muslims feeling adrift. ${ }^{57}$

Peace with Turkey, Gr. Brit.-Turk., Aug. 10, 1920, 1920 Gr. Brit. T.S. No. 11, http://reaties.fco.gov.uk/docs/pdf/1920/TS0011.pdf [http://perma.cc/U5P4-PBTT] (exemplifying treaty relations, though never adopted and superseded by the Treaty of Lausanne); British Mandate for Palestine, July 24, 1922, 3 L.N.O.J. 1007.

50 See Berque, supra note 29, at 269; William L. Cleveland, A History of the Modern Middle EAst 163-64 (3d ed. 2000) ("For the Arabs, the aftermath of [World War I] produced feelings of bitterness toward the Western powers and a deep-seated conviction that they had been betrayed."). Note after the First World War, the British supported "Syrian unity and Iraqi independence," but refused to loosen the British grip on Egypt. BERQue, supra, at 271.

51 Cleveland, supra note 50, at 161 (“[T] he mandate system was little more than nineteenth-century imperialism repackaged to give the appearance of selfdetermination.").

52 See Gregorio F. Zaide, World History in An Asian Setting 344 n.5 (1994).

53 Tom Reiss, The Orientalist: Solving the Mystery of a Strange and DANGEROUS LiFE 117-18 (2006).

54 ZAIDE, supra note 52.

55 Debjani Ganguly \& John Docker, Rethinking Gandhi and Nonviolent RELATIONALITY 251 (2007).

56 See Firas Alkhateeb, The Last Great Caliph: Abdülhamid II, LOST IsLAMIC HIST. (Apr. 6, 2013), http://lostislamichistory.com/the-last-great-caliph-abdulhamid-ii/ [http://perma.cc/A766-QWAR] ("Throughout Islamic history, one of the uniting aspects of the Muslim world was the caliphate."); IAN RiCHARD NETTON, ENCYCLOPEDIA OF ISLAMIC CiVILISATION AND RELIGION 504 (2008).

57 See Berque, supra note 29, at 269; Cleveland, supra note 50, at 161-64 ("[T] he mandate system was little more than nineteenth-century imperialism repackaged to give the appearance of self-determination."); ZAIDE, supra note 52, at 344 (describing Turkey's 
Between the two world wars, nationalism in Egypt and much of the Middle East was ascendant, but little progress toward ending English domination was made. ${ }^{58}$ Immediately after World War I, Britain arrested Egyptian nationalists, violently put down the ensuing revolt, ${ }^{59}$ and rejected their demands for independence. ${ }^{60}$ The breakup of the Ottoman Empire and the abolition of the Caliphate devastated much of the Arab and Muslim worlds, both economically and culturally. ${ }^{61}$ In a sense, the breakup was like creating the European Union in reverse. What had been a single, though somewhat loosely bound, empire, overnight became a group of new states (or at least new separately designated colonies or protectorates). ${ }^{62}$ Each of the newly created Arab or Muslim states all at once had foreign borders; each had its own customs and taxes. ${ }^{63}$ Former Ottoman Empire provinces that had little to do with one another were cobbled together to form a country (for example, Iraq was formed from three provinces of the Ottoman EmpireMosul, Bagdad, and Basra). ${ }^{64}$ Others, like Transjordan, were created because of squabbles between France and Britain over Syria. ${ }^{65}$ Fragmenting the Ottoman Empire weakened the whole, which was France and Britain's objective. ${ }^{66}$ Only Turkey's military might and its drastic drive towards modernity enabled it to escape

political strength at the time); REISS, supra note 53; Alkhateeb, supra note 56; GANGULY \& Docker, supra note 55; NetTon, supra note 56; Solomon A. Nigosia, Islam: ITS History, TEACHING, AND PRACTices 39 (2004) ("The abolition of the Caliphate offended Muslims everywhere ....”). But see Majid KhadDuRI, WAR AND PEACE IN THE LAw of ISLAM 291 (2006) (noting that Shaykh Ali Abd al-Raziq, one of the ulama of the Azhar University and judge of a sharia court, argued in support of a secular state and the abolition of the caliphate).

58 Cleveland, supra note 50, at 193.

59 Id.

$60 \mathrm{Id}$.

61 See Nigosia, supra note 57.

62 Dona Stewart, The Middle East Today: Political, Geographical and Cultural Perspectives 101-09 (2009).

63 Id. (explaining how the British and French divided up the Ottoman Empire); see also CAESAR E. FARAH, ISLAM 157 (7th ed. 2003).

64 Thomas X. Hammes, The Sling and the Stone: On War In the 21st Century 180 (2006).

$65 \mathrm{Id}$.

66 Stewart, supra note 62, at 95 (noting that the Allies wanted to ensure that the Ottoman Empire would never rise again). 
the colonial powers' grasp. ${ }^{67}$

The 1936 Anglo-British Treaty, though nominally ending British occupation of Egypt, ${ }^{68}$ allowed Britain to station 10,000 additional British troops in the Canal Zone. ${ }^{69}$ "With the advent of the Second World War, Britain effectively occupied the country again." 70

\section{B. The Rise of Nasser-the Secular, Authoritarian Military Leader}

As disappointment continued to sweep through the Arab World after the Second World War, all parts of the Egyptian population were agitating against British rule. ${ }^{71}$ Although the British had left the rest of Egypt largely alone, Britain stationed 80,000 troops in the Canal Zone. ${ }^{72}$ In January 1952, when the British used heavy weapons against the light-armed Egyptian police, there was a national outcry. ${ }^{73}$

67 See NigOSIA, supra note 57; STEWART, supra note 62 (explaining how the British and French divided up the Ottoman Empire); FARAH, supra note 63 (discussing the regions which possessed a geographically independent personality before Islam began to assert themselves under sectarian adhesion in Islam); HAMMES, supra note 64; Olivier Roy, Turkey - A World Apart or Europe's New Frontier?, in TURKEY TODAY: A EUROPEAN COUNTRY? 11 (2004).

68 Convention Concerning the Immunities and Privileges to be Enjoyed by the British Forces in Egypt art. 4, U.K.-Egypt, opened for signature Aug. 26, 1936, 1937 Gr. Brit. T.S. No. 6, https://upload.wikimedia.org/wikipedia/commons/d/de/Anglo-Egyptian Treaty_of_1936.pdf[https://perma.cc/UG5U-JZJJ]. The treaty did provide Egypt a British defense guarantee against then fascist Italy. See P.J. VATIKIOTIS, THE HistORY OF MODERN EGYPT 293 (1991) (expounding on Egyptian rights under the treaty).

69 VATIKIOTIS, supra note 68 , at 5.

70 SPRINGHALl, supra note 33 , at 14,88 . In the British view, the renewed de facto colonization of Egypt was justified because of the threat to the canal during the war for Allied shipping of supplies, material, and troops. Id.

71 Samia Mehrez, Translating Egypt's Revolution: The Language of Tahrir $22(2012)$.

72 Keith Kyle, Suez: Britain's End of Empire in the Middle East 40 (2011).

73 See C. N. Trueman, The Causes of the Suez Canal War of 1956, Hist. LEARNING SITE (May 25, 2015), http://www.historylearningsite.co.uk/modern-world-history-1918to-1980/the-cold-war/the-causes-of-the-suez-canal-war-of-1956causes_suez-crisis-1956. htm [http://perma.cc/8VBZ-EHPB]. One Egyptian commentator describes the forces that led to the Egyptian Army Revolt of July 23, 1952: "The presence of British troops in the Suez Canal Zone [was] widely resented as a national humiliation." NEJLA M. ABU IZZEDDIN, NASSER OF THE ARABS 5 (1975). 
This led to the Free Officers' revolt six months later ${ }^{74}$ in which some young military officers led a revolt against the monarchy and Britain. $^{75}$ All sectors of the population from religious fundamentalists to the secularists supported this revolt. ${ }^{76}$ It succeeded. ${ }^{77}$ Under the treaty of 1954 , Britain agreed to leave the Canal to the nationalist Egyptian governments. ${ }^{78}$ Although the British left Egypt, the Canal continued to be run by the Suez Canal Company, with predominant European ownership. ${ }^{79}$ After the revolt, Gamal Abdul Nasser, one of the Free Officers, became chair of the Revolutionary Command Council and later president of Egypt. ${ }^{80}$ Nasser espoused a pan-Arabian ideology, but along secular lines. ${ }^{81}$ Nearly four years to the day after the 1952 revolt, Nasser nationalized the Suez Canal. ${ }^{82}$

Britain and France reacted immediately and vehemently. ${ }^{83}$ Despite Egypt's offer to pay the European shareholders, the British

74 See IzZEDDIN, supra note 73, at 5-6 (describing the political and social climate when Cairo was burned in 1952).

75 See Arab Unity: Nasser's Revolution, AL JAZEERA (June 20, 2008), http://www.aljazeera.com/focus/arabunity/2008/02/200852517252821627.html [http:// perma.cc/Z7G2-DJMK] (describing the coup that brought the young Egyptian officials to power); Trueman, supra note 73.

76 Arab Unity, supra note 75.

77 Id.

78 Agreement Regarding the Suez Canal Base art. 1, Egypt-U.K., Oct. 19, 1954, 210 U.N.T.S. 3.

79 See The Suez Crisis, 1956, U.S. DeP'T. StATE, https://history.state.gov/milestones/ 1953-1960/suez [http://perma.cc/2KJF-TLPJ] (last visited Oct. 25, 2015).

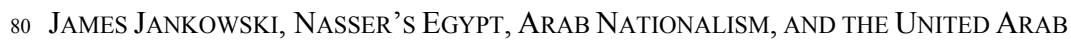
REPUBLIC 19 (2002); Arab Unity, supra note 75.

81 Arab Unity, supra note 75.

82 See id.; Agreement Between the Government of the Republic of Egypt and the Government of the United Kingdom of Great Britain and Northern Ireland art. 1, U.K.Egypt, Oct. 19, 1954, 210 U.N.T.S. 3 (describing the terms of the Suez Canal Base Agreement). King Farouk left the country to become a playboy on the Riviera. See Bernard Reich, Political Leaders of the Contemporary Middle East and North AFRICA 192-93 (1990). Nasser nationalized the canal one week after the United States and Britain withdrew funding for the Aswan Dam. See Milner, supra note 45. He said, "[T]he Canal will pay for the Dam." RAYMOnd Flower, NAPOLEON TO NASSER: The STORY OF MODERN EGYPT 180 (2001). Nasser offered to compensate the Canal Company shareholders, based on their share value on the French La Bourse, the French Stock Exchange, on the day before the nationalization. On This Day 26 July, 1956: Egypt Seizes Suez Canal, BBC (July 26, 2005), http://news.bbc.co.uk/onthisday/hi/dates/ stories/july/26/newsid_2701000/2701603.stm [http://perma.cc/L2WW-D5KA].

83 IZZEDDIN, supra note 73, at 192. 
and French saw the takeover as robbery of "their" Canal. ${ }^{84}$ Secretly, the French and the English encouraged Israel to invade Egypt and promised that they would supply air support and other material. ${ }^{85}$ On October 29, 1956, Israel invaded Egypt according to plan, and the French and British commenced an extensive bombing campaign against Egypt, as agreed. ${ }^{86}$ The Egyptians initially fought back, but later retreated from the Sinai ${ }^{87}$ Both the U.S.S.R. and the United States opposed the attacks on Egypt. ${ }^{88}$ On October 30, 1956, the United States introduced a resolution in the U.N. Security Council, "calling upon all countries to refrain from [using armed] force in the Middle East." 89 Both France and Britain vetoed the resolution. ${ }^{90}$

After intense pressure from the United States, the U.S.S.R., and

84 See Arab Unity, supra note 75; IzZEDDIN, supra note 73, at 192 (noting the sense of "alarm that the world was on the brink of a major conflict"); DAVID TAL, THE 1956 War: Collusion AND Rivalry IN THE Middle EAST 104 (2001) (documenting the protracted buildup to the Suez Crisis from the British perspective); Telegram from the Delegation at the Suez Canal Conference to the Department of State, U.S. DEP'T STATE, https://history.state.gov/historicaldocuments/frus1955-57v16/d104 [https://perma.cc/ 2YW9-7ZGC]. The British and the French rejected the U.S. proposal that they bring their case before the ICJ. See, e.g., Charlotte Peevers, The Politics of Justifying Force: The Suez Crisis, the IraQ War, AND InTERnAtional LaW 103 (2013).

85 See Milner, supra note 45. Given the hostility of Nasser towards Israel, the Israeli government participated in the attack in order to overthrow him. Id.

86 See Milner, supra note 45; IzZEDDIN, supra note 73, at 89, 187, 189-90; TAL, supra note 84, at 180 (quoting an aide to Israeli General Moshe Dayan observing the French bombing of Egyptian military bases, "The camps became an inferno").

87 See IzZEDDIN, supra note 73, at 189.

88 The Suez Crisis, 1956, supra note 79.

89 Permanent Rep. of the United States to the U.N., Letter dated Oct. 29, 1956 from the Rep. of the United States of America addressed to the President of the Security Council concerning: "The Palestine Question: Steps for the Immediate Cessation of the Military Action of Israel in Egypt," U.N. Doc. S/3710 (Oct. 30, 1956); see also Hugh Thomas, SuEz 134 (1967).

90 The Veto, SeCurity COUnCIL REP. (Aug. 3, 2015), http://www.securitycouncilreport.org/un-security-council-working-methods/the-veto.php [http://perma.cc/5DBZ-PXMT]. They also vetoed a Soviet resolution calling for a ceasefire and for Israel to withdraw from the Sinai. See also IzZEDDIN, supra note 73, at 192 (noting the ensuing paralysis of the Security Council and sense of alarm in the U.N. General Assembly that resulted from the vetoes). 
the international community, ${ }^{91}$ France and Britain backed down. ${ }^{92}$ The Israeli forces moved back from the Sinai. ${ }^{93}$

The two colonial powers lost, and, even though his army was defeated, Nasser became a hero in the non-aligned world. ${ }^{94}$ At least one commentator attributes the brisk pace of worldwide decolonization after the "Suez Affair" to the success of Nasser in nationalizing a primarily European-owned company and to the defeat of France and Britain in their attempts to retake the Canal. ${ }^{95}$

In the 1960s, Nasser (and other Arab leaders), increasingly made threats to Israel. ${ }^{96}$ Nasser also took threatening actions. On May 15, 1967, he began to mobilize his military forces and started putting them in the Sinai; he asked the U.N. Emergency Force to pull out and stop patrolling the Egypt-Israeli border; he closed the Straight of Tiran to Israeli ships; and he "talked openly" of attacking and destroying Israel. ${ }^{97}$ Israeli leaders agreed to negotiate, but the Arab leaders refused to do so. ${ }^{98}$ Faced with the provocative

91 The U.S.S.R. threatened both Britain and Israel; the United States told Britain that it would not financially support the pound sterling, which for other reasons had been losing value. Dag Hammarskjöld, the distinguished U.N. Secretary General, offered his resignation in protest of the attacks on Egypt. HALL GARDNER, AMERICAN GLOBAL STRATEGY AND THE "WAR ON TERRORISM" 87 (2007).

92 See Aron Shai, Suez: The Last Imperial War or an Imperial Hangover?, in THE 1956 WaR: Collusion ANd RivalRy In THE Middle EAST 19, 23 (David Tal ed., 2001).

93 Elie Podeh, Regaining Lost Pride: The Impact of the Suez Affair on Egypt and the Arab World, in The 1956 WAR: Collusion AND RivalRY IN THE MidDle EAST, supra note 92, at 209, 219. Israel retained the right of passage through the Straits of Tiran, a right not possessed before the attack. See Milton Viorst, Storm From the EASt: The StrugGle BetweEn the ARAB World AND the Christian West 105 (2006).

94 See Shai, supra note 92 ("Nasser . . . emerged as the Arab world's mightiest hero, having ... liberated his country from the fetter of imperialism.").

95 IzZedDin, supra note 73, at 197; COLE Christian KingSEe, EISENHOWER AND THE SUEZ CRISIS OF 1956, at 142 (1995).

96 See Deborah J. Gerner, One Land, Two Peoples: The Conflict over PALESTINE 111-12 (1994) (stating that "[t]he [1967] war was preceded by a period of increasing tension in the region[]" and detailing Egyptian and Syrian threats made towards Israel).

97 Id. (arguing Nasser's actions could fit Lebow's brinksmanship model); see also L. Carl Brown \& Richard B. Parker, Introduction to The SiX-Day WaR: A Retrospective 1, 7-9 (Richard B. Parker ed., 1996) (noting Nasser concluded he must "respond with some military action to deter Israel from attacking"); CHRISTOPHER GELPI, THE POWER OF LEGITIMACY 141 (2002) (“[T]he objective will be the destruction of Israel.”).

98 The Six-Day War: Background \& Overview, Jewish VIRTUAL LiBR., http://www.jewishvirtuallibrary.org/jsource/History/67_War.html [http://perma.cc/NJ7L53KG] (last visited Aug. 29, 2015). Although agreeing to U.N. mediation of the Israeli 
language and actions, Israel launched a preemptive attack on June 5, 1967, conquering Egypt, Syria, and Jordan, taking the Sinai from Egypt, the Golan Heights from Syria, and the Gaza Strip and the West Bank from Jordan. ${ }^{99}$ The United Nations and the commentators generally have agreed that Israel's preemptive attack was justified under international law. ${ }^{100}$

dispute, Nasser made extremely limited concessions. GELPI, supra note 97, at 14142 (noting Nasser: (1) gave assurances that "Egypt would not begin any military conflict," (2) "would accept U.N. mediation of the dispute with Israel," (3) "offered to open the straits to ships bound for Israel provided that the ships themselves were not Israeli and that they carried no strategic materials," and (4) "suggested that Israel bring the dispute to a close by inviting UNEF onto its territory").

99 See GELPI, supra note 97, at 145.

100 Although not expressly authorized under article 51 of the UN Charter, a preemptive attack is probably justifiable under customary international law in narrow circumstances. The legality of such an attack is usually evaluated under the Caroline case, requiring that the preemptive use of force "be confined to cases in which the necessity of that self-defense is instant, overwhelming, and leaving no choice of means, and no moment for deliberation."

Letter from Daniel Webster to Lord Ashburton (Aug. 6, 1842). A large body of legal scholars believe that Israel was entitled under international law to make a preemptive strike because the threat was imminent ("instant" and "overwhelming") and Israel had exhausted all peaceful means to avoid the use of military force. See, e.g., Michael P. Scharf, Clear and Present Danger: Enforcing the International Ban on Biological and Chemical Weapons Through Sanctions, Use of Force, and Criminalization, 20 MicH. J. INT'L L. 477, 491 n.71 (1999) ("Israel pursued alternative means to resolve the conflict ... [b]ut with the Arab leaders issuing increasingly bellicose threats, Israel issued a preemptory strike against the Egyptian airfields."); William V. O'BRIEN, The CONDUCT OF JUST AND LIMITED WAR 133 (1981) (arguing Israel's preemptory strike against Egypt as justified); Michael WAlzer, JUST AND UNJUST WARS 85 (4th ed. 2006) (recognizing Israel's preemptory strike on June 5, 1967 as justified); Alan M. Dershowitz, PreEMPTION: A KNIFE THAT CUTS BOTH WAYs 82 (2007) (justifying Israel's preemptive attack on June 5, 1967); Yoram Dinstein, War, Aggression and SElf-Defence 192 (4th ed. 2005) (arguing that Israel's attack on June 5, 1967 on Egypt was justified). But see Mary Ellen O'Connell, Lawful Self-Defense to Terrorism, 63 U. PITT. L REV. 889, 894 n.33 (2002) ("Subsequent evidence suggests that Israel knew Egypt did not plan to attack Israel . . . [and] [i]f so, Israel's attack was unlawful."). U.N. Security Council Resolution 242, however, calls upon Israel to return occupied territories, on the one hand, and Arab states to recognize and guarantee the security of Israel, on the other. S.C. Res. 242 (Nov. 22, 1967), http://unispal.un.org/unispal.nsf/0/ 7D35E1F729DF491C85256EE700686136 [http://perma.cc/E758-E3QU] ("The Security Council . . 1. Affirms that the fulfilment of Charter principles requires the establishment of a just and lasting peace in the Middle East which should include the application of both the following principles: (i) Withdrawal of Israel armed forces from territories occupied in the recent conflict; (ii) Termination of all claims or states of belligerency and respect for and acknowledgment of the sovereignty, territorial integrity and political independence of every State in the area and their right to 


\section{The Rise of al-Banna and the Muslim Brotherhood}

The British colonization of Egypt had provoked not only secular Egyptian nationalists, but also Islamic fundamentalists. ${ }^{101}$ In 1919, the then-thirteen-year-old Hasan al-Banna participated in the Egyptian uprising against the British. ${ }^{102}$ He grew to become a religious and nationalist leader. ${ }^{103}$ The First World War and its aftermath affected al-Banna and helped create the movement he led: 104

After the World War I, Turkey abandoned the Caliphate, discarded the Arabic alphabet, and carried out extensive reforms. These things had profound repercussions in Egypt. The Liberals seized this opportunity to issue literature on Egypt's relations with the West, the substitution of the Western hat for the fez, the emancipation of women, freedom of thought, and the like. On the other hand, the Conservatives held these to be a departure from the fold of Islam, the message of the Koran, the name of the Caliphate, and religion in its totality. It was their opinion that Egypt had become the headquarters of the Islamic mission, the field of its struggle, and the legal heir of its leadership. Al-Banna was among those of the latter party. ${ }^{105}$

In 1928, in Ismailia, Egypt, al-Banna founded the Muslim Brotherhood. ${ }^{106}$ A gifted speaker and organizer, al-Banna built the

live in peace within secure and recognized boundaries free from threats or acts of force ....").

101 See Profile: Egypt's Muslim Brotherhood, BBC (Dec. 25, 2013), http://www.bbc.com/news/world-middle-east-12313405 [http://perma.cc/6GKY-LGM4].

102 Musa Husaini, The Moslem Brethren 5 (1955).

103 See id. at 42-44 (discussing the various religious and nationalist principles of the Muslim Brotherhood).

104 Id. at 5.

105 Id. ("Mustafa Kemal [Ataturk] . . had announced the abolition of the Caliphate and separated the state from religion in a country which was until recently the site of the Commander of the Faithful [Amir al-Mu'minin]. The Turkish government proceeded rashly and blindly in this direction in all spheres of life... I saw the social life of the beloved Egyptian people, oscillating between her dear and precious Islam which she had inherited, defended, lived with during fourteen centuries, and this severe Western invasion which was armed and equipped with all destructive influences of money, wealth, prestige, ostentation, power and means of propaganda." (emphasis added)); MANUS I. MIDLARSKY, Origins of Political Extremism: Mass Violence in the Twentieth Century and BEyOND 17 n.46 (2011) (citing BRYNAR Lia, THE SOCIETY OF THE MOSLEM BROTHERS IN EGYPT 1928-1942, at 28 (1998)).

106 The group formed under the name, "Association of the Moslem Brethren." 
society into one of the most formidable organizations in Egypt, if not the Arab world. ${ }^{107}$ At its height, in the 1940s, the Muslim Brotherhood had over 500,000 registered members. ${ }^{108}$ The Brotherhood ran schools, health clinics, religious classes, other services, and also developed a clandestine military arm. ${ }^{109}$

In 1948, five weeks after declaring the Muslim Brotherhood illegal, the Egyptian prime minister was assassinated by a Muslim Brotherhood member. ${ }^{110}$ This murder led to the assassination of the forty-three-year-old al-Banna the following year, probably by an Egyptian government agent. ${ }^{111}$

The Muslim Brotherhood was the forerunner of those contemporary Arab-Muslim groups, including al-Qaeda and ISIS, which have targeted the West for violence. ${ }^{112}$ After al-Banna's assassination, Sayyid al-Qutb became the Brotherhood's philosophical and theological prophet as well as one of the organization's leaders. ${ }^{113}$ A skilled writer and deep thinker, al-Qutb went far beyond al-Banna and called not only for a Muslim state and for the recovery of all territory once under Muslim control, but also for world conquest and the imposition of Islam as the official world government and as the sole religion for all peoples of the world. ${ }^{114}$ After studying for a postgraduate degree at Colorado State College of Education (now University of Northern Colorado) from 1948 to 1951, al-Qutb returned to Egypt with a special antipathy towards the United States, its culture, and its people. ${ }^{115}$

HUSAINI, supra note 102, at 1-2.

107 See Profile: Egypt's Muslim Brotherhood, supra note 101.

108 HuSAINI, supra note 102, at 18.

109 See Christine S. Rinehart, Volatile Social Movements AND the Origins of TERRORISM: THE RADICALIZATION 29 (2013). The Brotherhood's popularity is probably due both to its opposition to foreign control and to the fact that it provides a "safety net" via charitable and social programs. See Dina SheHATA, Islamists AND SeCUlarists in EGYPT: OPPOSITION, CONFLICT, AND COOPERATION 54 (2010) ("[T] he social services and charitable activities provided by the Brotherhood helped create social safety net at a time of economic retrenchment.").

110 RINEHART, supra note 109, at 23.

111 See Youssef M. Choueiri, Islamic Fundamentalism 59 (3d ed. 2010).

112 MCDONNELL, supra note 7, at 11.

113 See CHOUEIRI, supra note 111, at 62.

114 See David Bukay, From Muhammad to Bin Laden 215-16 (2007).

115 See SteWART, supra note 62, at 176-78. Qutb's dislike of the United States can probably be attributed to his perception that Americans had reacted "triumphant[ly]" to Israel's independence and to Americans' "jubilant" response to Hasan al-Banna's 
Al-Qutb and the Muslim Brotherhood had crossed paths with the new government since the Free Officers' successful liberation of Egypt from Britain in 1952. ${ }^{116}$ Although initially supporting the government, the Muslim Brotherhood soon stood at odds with Nasser's secular state. ${ }^{117}$ Some members of the Muslim Brotherhood engaged in violence against state officials, including at least one assassination attempt against Nasser in 1954, which led to the Brotherhood's "forcible suppression."118 Although al-Qutb did not directly take part in such violence, he was tortured and imprisoned for many years. ${ }^{119}$ He was subsequently accused of plotting against the State and against its president. ${ }^{120}$ Nasser had him executed in 1966, elevating al-Qutb to martyrdom status in the eyes of Islamic fundamentalists. ${ }^{121}$ Al-Qutb's philosophical writings have become the holy writ of today's Muslim fundamentalist movements. ${ }^{122} \mathrm{He}$ is said to have inspired Osama bin Laden ${ }^{123}$ and Ayman al-Zawahiri. ${ }^{124}$

Up until 1967, most Muslims looked up to Nasser and admired his pan-Arab nationalism, and his apparent modernization of

assassination. See James Toth, SAyyid Qutb: The Life and Legacy of a Radical ISLAMIC INTELLECTUAL 65 (2013) (noting that Outb's "American sojourn" made him an "extreme radical"). He was also apparently distressed by the "seductive atmosphere" in the United States upon seeing girls and boys dancing closely together at a church social. Id.

116 Profile: Egypt's Muslim Brotherhood, supra note 101.

117 See id.

118 Muslim Brotherhood, ENCYC. BRITANNICA, http:/www.britannica.com/topic/ Muslim-Brotherhood [http://perma.cc/T7DW-JXHB] (last updated Nov. 24, 2014).

119 See Richard Rubenstein, JiHAD And Genocide 18-19 (2010).

$120 \mathrm{Id}$. at 18.

121 Id. at $18-19$.

122 Id. at 18.

123 See Richard C. Martin, Encyclopedia of Islam And the Muslim World 108 (2004) (observing that Osama bin Laden was taught by Muhammad Qutb, Sayyid Qutb's brother); RUBENSTEIN, supra note 119, at 19-20 (noting the power of al-Qutb's choosing death rather than compromising his beliefs).

124 See MARTin, supra note 123. Al-Qutb heavily influenced Ayman Zawahiri as well. See Clark McCauley \& Sophia Moskalenko, Friction: How Radicalization HAPPENS TO THEM AND Us 30 (2011) (noting Zawahiri's uncle was Qutb's lawyer); RuBENSTEIN, supra note 119, at 19-20. 
Egypt. ${ }^{125}$ Islamic fundamentalists held relatively little power. ${ }^{126}$ The Israeli success in the 1967 War (also called the Six Day War), however, had a devastating impact on the secular Arab governments. ${ }^{127}$ They were discredited in the eyes of their people. ${ }^{128}$ Because of the failure of these governments vis-à-vis Israel, domestically, the pendulum began to swing away from the secular modernizing governments epitomized by Nasser, and by the Shah of Iran, to the "conservative" Muslim fundamentalists, epitomized by the Muslim Brotherhood. ${ }^{129}$ There is a competition going on in the Islamic world between the "conservative" fundamentalists and the "liberal" modern secularists. ${ }^{130}$ From 1967 to 2011, we probably witnessed the rise of fundamentalism in the Muslim world, with the possible exception of Iran. ${ }^{131}$ There, actual experience of living under an Islamic state fueled an active opposition, which, has not yet become strong enough to displace the mullahs. ${ }^{132}$ The Arab

125 See David S. Sorenson, The Dynamics of Political Dissent in Egypt, 27 FLETCHER F. WORLD AFF. 207, 212 (2003).

126 Id.

127 Id.

128 Id. ("[T]he appeal of political Islam grew after the disastrous Egyptian defeat in the 1967 war."); see also ARMSTRONG, supra note 16, at 171 ("People felt that the Muslims had failed because they had not been true to their religion."); LOREN D. LYBARGER, Identity and Religion in PAlestine: The Struggle Between Islamism and SECUlARISM IN THE OCCUPIED TERRITORIES 23-25 (2007) (noting that Nasser's humiliating defeat led to the reconstruction of the Muslim Brotherhood in Palestine); Gérard Chaliand, From 1968 to Radical Islam, in THE HiSTORY OF TERRORISM FROM ANTIQUITY TO AL QAEDA 221, 225, 240-41, 245 (2007) ("The victory of 1967 had been unqualified, the humiliation of the Arab states complete.").

129 See VATikiotis, supra note 68, at 420-21 ("In fact, inter-communal conflict began to gather momentum soon after the military debacle of June 1967. It was, in a sense, one of the inevitable consequences of the disappointment with and the insecurity felt under the Nasser regime. There was steady proliferation of militant religious organizations in both the Muslim and Coptic communities, especially among university students. This process of militant religious resurgence was accelerated by Nasser's failing socialist policies followed by Sadat's pro-Western economic liberalization [policy and his alliance with rich, conservative oil-producing Arab states after 1971]. A suitable climate for religious militancy was created by both leaders, especially Sadat.").

130 MCDonnell, supra note 7, at 12.

131 Id.

132 See Joby Warrick \& Julie Tate, High-Priced Advocacy Raises Questions for Supporters of Iranian Exile Group, WASH. POST (July 5, 2012), https://www. washingtonpost.com/world/national-security/high-priced-advocacy-raises-questions-forsupporters-of-iranian-exile-group/2012/07/05/gJQABoacQW_story.html [https://perma. cc/AGB8-2Y56]; Eric Shawn, Iran Resistance Leader Predicts Regime Change in 
Spring, however, may have signaled a return to the rise of secularism in the Arab and Muslim worlds. "133 "Conservative" fundamentalists, have been strengthened by internal domestic policies of Islamic states. ${ }^{134}$ Nasser, for example, ruled with an iron fist, imprisoning political opponents, torturing them and, in some cases, executing them. ${ }^{135}$ He took repressive measures against the Muslim Brotherhood, which had opposed his secularizing of Egyptian society. ${ }^{136}$

\section{Anwar al-Sadat}

Following Nasser's unexpected death in 1970, Vice President Anwar al-Sadat, one of the original "Free Officers" in the war of independence, took office on an interim basis and then consolidated his control by purging political rivals. ${ }^{137} \mathrm{He}$ is most noted for three things: his attack on Israel on Yom Kippur in 1973, his trip to Jerusalem in 1977, and his agreeing to the Camp David Accords in 1979. ${ }^{138}$ The attack on Yom Kippur caught the Israelis off guard. ${ }^{139}$ The Egyptians initially retook large portions of the western Sinai. ${ }^{140}$ The United States soon provided military supplies to Israel, including tanks and other weapons, helping Israel retake the

Exclusive Fox News Interview, Fox News (June 27, 2014), http:// www.foxnews.com/world/2014/06/27/iran-resistance-leader-predicts-regime-change-inexclusive-fox-news-interview/ [http://perma.cc/ZFT3-APAM] (describing the failed attempts of the Peoples' Mujahdin Organization of Iran (MEK) to remove the mullahs).

133 Juan Cole, The New Arabs: How the Millennial Generation Is Changing THE MidDLE EAST, at X-xii (2014). One colleague notes, however, that except for Iran and Saudi Arabia, most Arabs were secular, even before the Arab Spring. Comments of Professor Sahar Aziz (2015) (on file with author). She stated that Arabs were not becoming more secular but instead wanted a more liberal, democratic government. Id.

134 MCDonnell, supra note 7, at 12.

135 Id.

136 John L. Esposito \& John O. Voll, Islam And Democracy 174 (1996).

137 Eric Pace, Anwar el-Sadat, the Daring Arab Pioneer of Peace with Israel: Sadat's Innovations Sprang from His Courage and Flexibility, N.Y. TIMES (Oct. 7, 1981), http:// www.nytimes.com/1981/10/07/obituaries/anwar-el-sadat-daring-arab-pioneer-peace-with -israel-sadat-s-innovations-sprang.html?pagewanted=all [http://perma.cc/9X7F-VUG4]; see also VATIKIOTIS, supra note 68 , at $414-15$.

138 See Pace, supra note 137.

139 See generally Aryeh Shalev, IsRael's Intelligence Assessment Before the Yom KipPUR WAR: Disentangling DECEPTION AND Distraction (2010) (examining gaps in Israeli intelligence and Israel's immediate and long-term responses).

140 See id. at 31-32 (contrasting Egypt's success in first two days of war with subsequent reversal). 
Sinai. ${ }^{141}$ These efforts led directly to the Arab oil boycott of $1973 .{ }^{142}$ Yet Egypt's initial success probably enabled Sadat to go to Jerusalem and to agree to the Camp David Accords. ${ }^{143}$

The relative "openness" under Sadat allowed the Muslim Brotherhood to reestablish itself. ${ }^{144}$ Sadat, however, imprisoned and, in some cases, tortured extremists from both the left and the right. ${ }^{145}$ In 1981, he arrested "over 1,500 religious militants," a move that outraged the fundamentalist opposition. ${ }^{146}$ Although generally popular in Egypt, Sadat had been reviled by Muslim fundamentalists, such as the Muslim Brotherhood, Egyptian Islamic Jihad ("al Jihad"), and the Gamaa al Islamiya ("GIA"). ${ }^{147}$ At this time, al Jihad and GIA "broke from the Muslim Brotherhood, specifically because the Brotherhood had now refused to consider the use of violence."148 These Islamic fundamentalist organizations

141 Memorandum of Conversation between Henry A. Kissinger, U.S. Sec'y of State, and Simcha Dinitz, Israeli Ambassador to the United States, in the Map Room of the White House (Oct. 9, 1973) (transcript available at http://nsarchive.gwu.edu/NSAEBB/ NSAEBB98/octwar-21b.pdf [http://perma.cc/5HXP-BT73]).

142 James K. Hickel, The Role of Expropriation in the Formation of the OPEC Cartel, 2 ENERGY L.J. 107 (1981). 2010).

143 See EnCyClopedia of Africa 340 (Anthony Appiah \& Henry Louis Gates eds.,

144 See Abdullah Al-Arian, Answering the Call: Popular Islamic Activism in Egypt 9 (2014); Michele Dunne et al., Egypt - Don't Give up on Democracy Promotion, CARnegie Endowment For InT'L Peace, June 2007, at 1, 4 ("President Anwar Al Sadat reinstitutes limited pluralism, allowing the creation of a few loyal opposition parties and the reactivation of the Muslim Brotherhood."); Müge Aknur, The Muslim Brotherhood in Politics in Egypt: From Moderation to Authoritarianism?, 9 REV. INT'L L. \& POL'Y 1, 7 (2013) ("A new era started for the Muslim Brotherhood when Nasser's successor, President Anwar Sadat, encouraged the Islamists in order to counterbalance secular opposition from Nasserist, Marxist, and nationalist circles . . . [and] strengthened political Islam in Egypt, releasing hundreds of members of the organization and other political prisoners.").

145 See Caroline Goerzig, Egypt's Gama'a Islamiya: Change Through Debate?, in Engaging Extremists: Trade-OfFs, Timing, And Diplomacy 203, 207-11 (I. William Zartman \& Guy Oliver Faure eds., 2011); Kevin Dwyer, Arab Voices: The Human Rights Debate in the Middle East 61 (1991).

146 See VATikiotis, supra note 68, at 420, 424.

147 See Mathieu Guidère, Historical Dictionary of Islamic Fundamentalism 88-89, 103-04 (2012). GIA and al Jihad were formed by "dissident" groups of "former members of the Muslim Brotherhood." Id. GIA was one of the foundational groups forming al-Qaeda; al Jihad merged with al-Qaeda in 2001. Id.

148 Krista E. Wiegand, Bombs ANd BALlots: GovernanCE By ISLAMist TERrorist AND Guerrilla Groups 1-2 (2010); see also Goerzig, supra note 145, at 207 ("Feeling 
"could not forgive [Sadat] for recognizing Israel or for his role in the trial and execution of their ideological prophet, al-Qutb, for whom Anwar Sadat was one of the judges who ordered al-Qutb's execution. $^{149}$ An assassin closely linked to the GIA and al Jihad later led by Ayman al-Zawahiri, killed Anwar Sadat at a parade on October $6,1981 .^{150}$

"[I]mplicated in the Sadat assassination,"151 two Egyptians later came to Peshawar, Afghanistan, to struggle against the Soviet occupation there. ${ }^{152}$ These men were the blind cleric Omar Abdel Rahman and Ayman al Zawahiri, who later became bin Laden's top lieutenant ${ }^{153}$ and is now the head of al-Qaeda. ${ }^{154} \mathrm{Al}$ Zawahiri was arrested at the age of fifteen for being a member of the Muslim Brotherhood; Rahman was the spiritual leader of those members of al Jihad that carried out the assassination of Sadat. ${ }^{155}$ Rahman ultimately immigrated to the United States and planned the 1993 World Trade Center bombing. ${ }^{156}$ Zawahiri was tortured for his alleged complicity in the Sadat assassination. ${ }^{157}$ Lawrence Wright notes that the seeds for $9 / 11$ may very well have been sown in Egypt's torture chambers. ${ }^{158}$

that the Brotherhood had achieved little in all its years, Gama'a Islamiya eventually rejected the Brothers' accommodating path and decided that the way to achieve an Islamic state was through a revolutionary Islamic mass movement.").

149 See David Sagiv, Fundamentalism and Intellectuals in Egypt 6 (1995).

150 See Mohamed Fahmy, 30 Years Later, Questions Remain over Sadat Killing, Peace with Israel, CNN (Oct. 6, 2011), http://www.cnn.com/2011/10/06/ world/meast/egypt-sadat-assassination [http:// perma.cc/K24S-Y6WD].

151 Richard Bernstein, Out of the Blue 16 (2002).

152 Id.; see also Lawrence Wright, The Man Behind bin Laden, New Yorker, Sept. 16, 2002, at 56, 58; Peter Tomsen, The Wars of Afghanistan: Messianic Terrorism, Tribal Conflicts, AND the Failure of Great Powers (2013).

153 See Wright, supra note 152.

154 Al-Qaeda’s Remaining Leaders, BBC (June 16, 2015), http://www.bbc.com/news/ world-south-asia-11489337 [http://perma.cc/8YV9-TTWE].

155 See BERnSteIn, supra note 151 (citing Rahman's fatwa calling for Sadat's assassination).

156 Id.; see also 1993 World Trade Center Bombing Fast Facts, CNN (Feb. 13, 2015), http://www.cnn.com/2013/11/05/us/1993-world-trade-center-bombing-fast-facts [http:// perma.cc/FVX8-5JKH].

157 See BeRnsteIn, supra note 151, at 39-40 (citing video footage from Zawahiri's trial); Brian Till, A Note on Egyptian Torture, ATLANTIC (Feb. 11, 2011) http://www. theatlantic.com/international/archive/2011/02/a-note-on-egyptian-torture/70476 [http:// perma.cc/6WBU-T7QV].

158 Lawrence Wright, The LoOming Tower 52 (2007); see also Al-Arian, supra 


\section{The United States, Egypt, and the Middle East}

\section{A. The United States Assumes the Mantle of a Colonial Power.}

The United States never colonized a Muslim nation. ${ }^{159}$ But it gradually assumed-at least for Muslims - the mantle of colonization over the Middle East, particularly after the Second World War. ${ }^{160}$ The United States showed relatively little interest in the Middle East until American oil executives discovered oil in Bahrain and Kuwait in the 1930s. ${ }^{161}$ From the end of the Second World War to the end of the Cold War in 1990, the concerns that drove United States' policies in the Middle East region included ensuring the supply of oil, supporting Israel, ${ }^{162}$ and containing communism. ${ }^{163}$ To guarantee that oil is readily available, ${ }^{164}$ the

note 144, at 92 (noting that Nasser brutally tortured Muslim Brotherhood members).

159 See Nasr, supra note 6, at 551-58 (omitting mention of any U.S. colonization).

160 See Toby Craig Jones, America, Oil, and War in the Middle East, 99 J. Am. Hist. 208, 211-12 (2012) (discussing U.S. support for autocratic leaders such as the shah in Iran).

161 Id. at 208; Yasumasa Kuroda, Bush's New World Order: A Structural Analysis of Stability and Conflict in the Gulf, in THE GULF WAR AND THE NEW WORLd ORdER 52, 5960 (Tareq Y. Ismael \& Jacqueline Ismael eds., 1995).

162 Jones, supra note 160 , at 208. Muslims were not the only parties in the Middle East who suffered from conquest, colonization, and discrimination. The United States' policy toward Israel stems in part from Russia's and the Christian West's attitudes and conduct toward the Jewish people. The Christian West has practiced systematic discrimination against Jews for over 2000 years (and the Russians have done so for at least a millennium). A full discussion of the West's invidious and genocidal discrimination against the Jewish people as well as the creation of the modern state of Israel is beyond the scope of this article. For an enumeration of discriminatory and genocidal treatment of the Jews throughout history, see MCDonNELL, supra note 7, at 14-16 (documenting the historical persecution of Jews).

1632 Joseph R. COnlin, The American Past: A Survey of AmErican History 756 (10th ed. 2014).

164 Since the late 1970 s, U.S. dependence has generally fluctuated between 30 and $49 \%$, exceeding $60 \%$ in 2007 and declining to $49 \%$ in 2010 ; it dipped below $30 \%$ in the early 1980s. NeElish Nerukar, Cong. Research SERV., R41765, U.S. Oil ImPorts: Context And Considerations 1 (2011); see also How Much Petroleum Does the United States Import and From Where?, U.S. ENERGY INFO. ADMIN., http://www.eia.gov/tools/faqs/faq.cfm?Id=727\&t=6 [http://perma.cc/Z8LN-4Q36] (last visited Aug. 29, 2015) ("Net imports accounted for $27 \%$ of the petroleum consumed in the United States, the lowest annual average since 1985."). Despite the last few years, the trend of the United States depending on foreign oil remains significant. Because oil is critical to the U.S. economy, U.S. foreign policy for decades has been geared to ensuring 
United States has supported authoritarian regimes in the Arab world, including the House of Saud in Saudi Arabia, the Shah of Iran, ${ }^{165}$ Hosni Mubarak in Egypt, and, initially, Saddam Hussein in Iraq, not to mention autocratic leaders of the tiny, oil-rich Gulf states ${ }^{166}$ - Bahrain, Kuwait, Oman, Qatar, and the United Arab Emirates. ${ }^{167}$ For most of its history, the United States has been indifferent to the plight of Arab and Muslim peoples living in these countries, to their economic difficulties, and to the human rights deprivations they have had to bear. ${ }^{168}$

a readily available supply of oil. See generally STEPHEN J. RANDALL, UNITED STATES Foreign Oil Policy Since World War I: For Profits ANd Security 38, 152-53 (2005) (noting "the formulation of United States petroleum policy during World War II").

165 David Harris, The Crisis: The President, the Prophet, and the Shah-1979 AND THE COMING OF MiLiTANT IsLAM 23, 47-48 (2004) (explaining how, significantly, the Shah's father, Mohammad Reza Pahlavi, was supported by the United States).

166 MCDONNELL, supra note 7, at 14.

167 See Nader Hashemi, The Arab Spring, U.S. Foreign Policy, and the Question of Democracy in the Middle East, 41 DenV. J. INT'L L. \& POL'Y 31, 35-36 (2012); Ved Nanda, Arab Spring, the Responsibility to Protect, and the U.S. Foreign Policy-Some Preliminary Thoughts, 41 DENV. J. INT'L L. \& POL'Y 7, 12 (2012) (describing the resolution of Israel's strike against the Gaza strip through an American diplomatic push). See generally 2013 U.S. DEP'T STATE U.A.E. HuM. RTS. REP., http://www.state.gov/ documents/organization/220592.pdf [https://perma.cc/CRK8-UMMJ] (describing United Arab Emirates' human rights report for 2013); 2013 U.S. DEP'T STATE BAHR. HuM. RTS. REP., http://www.state.gov/documents/organization/220560.pdf [https://perma.cc/5EXL5LDS] (describing Bahrain's human rights report for 2013); Qatar U.N. Review: Crucial Reforms Needed to Protect Women and Migrant Workers, AMNESTY INT'L (May 7, 2014), http://www.amnesty.org/en/latest/news/2014/05/qatar-un-review-crucial-reforms-needed -protect-women-and-migrant-workers/ [http://perma.cc/5S5H-624W] (describing Qatar's U.N. Review and the country's need to protect women against domestic violence and migrant workers' rights); Annual Report 2012, Kuwait, AMNESTY INT'L (May 23, 2013) http://www.amnestyusa.org/research/reports/annual-report-kuwait-2013 [http://perma.cc/ F5ER-LV2V] (describing Kuwait's discrimination towards women and migrant workers); FreEdOM HouSE, FREEDOM IN THE WORLD 18-23 (2014), https://freedomhouse.org/ sites/default/files/Freedom\%20in\%20the\%20World\%202014\%20Booklet.pdf [https:// perma.cc/A93N-8LN2] (rating the four small Gulf States "not free," except for Kuwait, which earned a "part free" rating). On U.S. dependence on Arab oil, see GAD G. GILBAR, The Middle East Oil Decade And Beyond 52-53 (1997) (noting the significant effect of petroleum on U.S. foreign policy decisions).

168 MCDONNELL, supra note 7 , at 14 . Some commentators note "[t]he tragedy of U.S.-Middle East policy is that the United States has not been celebrated for its selfless devotion to democracy, but rather it has been bitterly criticized for not showing the slightest commitment to democracy whether [that be] in Turkey, Iran," or other Arab and non-Arab Middle Eastern countries "with the sole exception of Israel." ANDREW ROSS \& Kristin Ross, ANTI-AmERICANISM 115 (2004); see also MARWAN Bishara, The Invisible Arab: The Promise And Peril of the Arab Revolutions 42 (2012) 


\section{B. The Perceived Communist Threat}

From the onset of the Cold War, the United States had been determined to stem the tide of communism. ${ }^{169}$ In this fierce clash, the United States moved aggressively to ensure that the Soviet Union would not extend its influence in the Middle East. ${ }^{170 ~ " A m o n g ~}$ other things, the United States engineered the coup in 1953 against the elected Prime Minister of Iran, Muhammad Mossadegh, because of largely unsupported claims that he was leaning towards the communists. ${ }^{171}$ In 1963, the CIA again engineered a coup in Iraq, ousting communist-leaning General Abdel Karim Kassem and putting in his place Abu Salam Arif of the Ba'ath Party in 1963. ${ }^{172}$ That ouster ultimately led to Saddam Hussein taking control of the country. ${ }^{173}$

When the United States refused to finance the Aswan Dam because Nasser had purchased military equipment from Czechoslovakia - then a Soviet satellite-Nasser turned to the U.S.S.R. ${ }^{174}$ Nasser's turn to the communist bloc led the United States to work against him. ${ }^{175}$

The Islamic revolution in Iran upset the order that the United States helped establish. ${ }^{176}$ The U.S. support for Saddam Hussein's war against Iran can be seen, to a certain extent, to fall within this context. ${ }^{177}$ The next major cleavage arose when Saddam Hussein invaded Kuwait. No longer considered a reliable U.S. partner, Saddam Hussein was attacked by a broad coalition led by the United

\footnotetext{
(discussing petrodollar subsidization of Arab government despotism).

169 See Ross \& Ross, supra note 168.

170 Conlin, supra note 163.

171 See Stephen Kinzer, Overthrow: America's Century of Regime Change FROM HAWAII TO IRAQ 122 (2006).

172 Chalmers Johnson, The Sorrows of Empire: Militarism, Secrecy, and the END OF THE REPUBLIC 223 (2004).

173 Id. at 224.

174 Not coincidentally, Nasser nationalized the Suez Canal exactly one week after the U.S. Secretary of State John Foster Dulles told him that the United States was withdrawing financial support for the Aswan Dam. See Milner, supra note 45, at 3. At the same time the World Bank withdrew its pledge of \$200 million. Id.

175 See The Suez Crisis, 1956, supra note 79; Milner, supra note 45 (discussing the backlash that occurred because of the communist bloc's involvement).

176 See Krysta Wise, Islamic Revolution of 1979: The Downfall of American-Iranian Relations, 11 LEGACY 1, 1 (2011).

177 S.C. Res. 660, 19 (Aug. 2, 1990) (condemning the invasion of Kuwait by Iraq).
} 
States. ${ }^{178}$ Significantly, the repressive House of Saud requested that the United States post standing troops in Saudi Arabia as a protection force against Iraq. At one point, half a million U.S. troops were stationed on the ground in the country containing the two holiest places in Islam, Mecca and Medina. ${ }^{179}$

All these policies and practices of the United States were not lost on Arabs and Muslims. With the end of the Cold War, the counterweight to the United States, Russia, was a far less significant presence in the Middle East than the former Soviet Union had been. ${ }^{180}$ The United States had now taken the step of actually stationing troops in the holiest land of Islam. ${ }^{181}$ Osama bin Laden's first fatwa, in 1996, was entitled, "Declaration of Jihad against the Americans Occupying the Land of the Two Holy Places."182 The invasion of Afghanistan, and even more importantly the 2003 invasion of Iraq, further underscored, in Muslim eyes, the United

178 Jones, supra note 160 , at 216.

179 Toby Jones, Shifting Sands: The Future of U.S.-Saudi Relations, 85 ForeIGN AfF. 164, 166 (2006).

180 See P.J. VAtikiotis, Middle EAst, From the END of EMPIRE to the END of ThE COLD WAR 54 (1997) (discussing the European community and union).

181 U.S. Pulls out of Saudi Arabia, BBC (Apr. 29, 2003), http://news.bbc.co.uk/ 2/hi/middle_east/2984547.stm [http://perma.cc/A2H6-E5MM].

182 See Bin Laden's Fatwa, PBS NewsHour (Aug. 23, 1996), http://www.pbs.org/newshour/updates/military-july-dec96-fatwa_1996 [http://perma.cc/ 2MDZ-AMB9]. Reading Osama bin Laden's writings, one gets the clear impression that his holy war against the United States and against all Americans was triggered more by the stationing of troops in Saudi Arabia than by U.S. support of Israel; he does, however, characterize the "enemy" as the "American-Israeli alliance." MCDONNELL, supra note 7, at 16. The British support of Abdul Aziz ibn-Saud during World War I likewise helped him emerge as the ruler of Saudi Arabia. SCOTT ANDERSOn, LAWRENCE IN ARABIA: WAR, Deceit, Imperial Folly And the Making of the Modern Middle East 165 (2013). Thomas Edward Lawrence (Lawrence of Arabia) argued that despite posing as Islamic reformists "“with all the narrow minded bigotry of the puritan,' ibn-Saud and his Wahhabists were hardly representative of Islam [but] . . marginal medievalists, 'and if it prevailed, we would have in place of the tolerant, rather comfortable Islam of Mecca and Damascus, the fanaticism of Nejd . . intensified and swollen by success." Id. at 173. Because of their oil wealth, the House of Saud has helped Wahhabism spread throughout the world and has contributed both to the growth of al-Qaeda and ISIS. See Yousaf Butt, How Saudi Wahhabism Is the Fountainhead of Islamist Terrorism, HuFFINGTON Post (Jan. 20, 2015), http://www.huffingtonpost.com/dr-yousaf-butt-/saudi-wahhabism-islamterrorism_b_6501916.html [https://perma.cc/9VSX-YNDW] ("The fight against ISIS and Al-Qaeda is deeply ironic since these organizations were created and are sustained, in part, by funds we hand over to the Saudis and Gulf Arab nations to purchase their oil."). Lawrence has proved to be prescient. 
States assuming the familiar role of Western colonial overlord. ${ }^{183}$ Query whether the 2003 U.S. invasion of Iraq and other U.S. counter-terrorism policies and practices contributed to the rise of ISIS.

\section{The Arab Spring, the Military Coup d'État, and the Following Repression}

\section{A. The Disappointing Outcome of the Arab Spring}

The Arab Spring swept through the Middle East on January 25, 2011, sparked by the self-immolation of a young street vendor fed up with both the harshness and pettiness of the Tunisian largely one party regime. ${ }^{184}$ The ensuing massive protest unexpectedly resulted in the Tunisian military dictator falling. ${ }^{185}$ Egypt, Libya, Syria, Bahrain, and Yemen followed, with massive protests of their own. ${ }^{186}$ Led by young secularists seeking modern democracies more or less on European lines (or at least Turkish ones), the Arab Spring has borne some good, but much bitter fruit.

Tunisia has established a developing democratic government. ${ }^{187}$

183 Max Fisher, Who Loves and Hates America: A Revealing Map of Global Opinion Toward the U.S., WASH. POST (Jan. 11, 2013), https://www.washingtonpost.com/news/ worldviews/wp/2013/01/11/who-loves-and-hates-america-a-revealing-map-of-global-opi nion-toward-the-u-s/ [https://perma.cc/2LJ3-K6JP]. For a discussion of the relationship between Western colonization of Muslim lands and Islamic terrorism, see MCDONNELL, supra note 7 , at $1-18$.

184 The Arab Spring: A Year of Revolution, NPR (Dec. 17, 2011), http://www.npr.org/ 2011/12/17/143897126/the-arab-spring-a-year-of-revolution [http://perma.cc/XS73MPW8].

185 M. Cherif Bassiouni, The "Arab Revolution" and Transitions in the Wake of the “Arab Spring,” 17 UCLA J. InT'L L. \& ForEIGN AfF. 133, 143 (2013); see also Naseema Noor, Tunisia: The Revolution That Started It All, INT'L AfF. REV. (Jan. 31, 2011), http://www.iar-gwu.org/node/257 [http://perma.cc/RWT8-3R4Y] (describing how Tunisia brought down the regime).

186 Ismaeel Naar, Timeline: Arab Spring, AL JAZEERA (Dec. 17, 2013) http://www. aljazeera.com/indepth/interactive/2013/12/timeline-arab-spring-20131217114018534352 .html [http://perma.cc/4LVL-8DKJ].

187 Carlotta Gall, Islamist Party in Tunisia Concedes to Secularists, N.Y. TIMES (Oct. 27, 2014), http://www.nytimes.com/2014/10/28/world/africa/nidaa-tounes-ennahdatunisian-parliamentary-election.html?_r=0 [http://perma.cc/MX6W-ZT75]; Michael R. Gordon, Kerry Makes Surprise Stop in Tunisia, N.Y. TIMES (Feb. 18, 2004), http:// www.nytimes.com/2014/02/19/world/africa/secretary-of-state-john-kerry.html [http:// perma.cc/N78N-X9ZH]; see also FrEEDOM House, supra note 167 (highlighting reports on political rights and civil liberties). But see Nanda, supra note 167 (observing that they lack a genuine democracy). 
Bahrain, however, imprisoned hundreds of peaceful protesters and their leaders. ${ }^{188}$ Libya's long-time dictatorial and mercurial leader Muammar el-Qaddafi had his forces gun down peaceful protesters, ultimately leading to U.N. Security Council intervention, Qaddafi's death and downfall, and to continued turmoil. ${ }^{189}$ Yemenis brought down their dictatorial president, Ali Abdullah Seleh, but have been thrown into chaos. ${ }^{190}$ Syria's al-Assad brutally used military force against peaceful protesters, ultimately pushing the country into a bloody civil war, attacking the so-called moderate Free Syrian Army, initially leaving ISIS largely untouched, and helping them to control vast territory. ${ }^{191}$ Egypt yet again experienced a more unique cycling from military dictatorship to freely elected civilian rule back to what is essentially a military dictatorship. It is this last country on which this article concentrates.

\section{B. Hosni Mubarak, His Human Rights Violations, and the United States}

Succeeding Sadat in 1981, former Air Force Commander and Vice-President Hosni Mubarak ruled dictatorially. ${ }^{192}$ During the nearly thirty years Mubarak was in power as president of Egypt, the United States gave to Egypt more than $\$ 62$ billion in military and civilian aid. ${ }^{193}$ Under the Camp David Accords and the Special International Security Assistance Act of 1979 enacted to support the Israeli-Egyptian peace agreement, Egypt has received almost as

188 Zainab al-Khawaja, Opinion, Bahrain, a Brutal Ally, N.Y. Times (Dec. 25, 2012), http://www.nytimes.com/2012/12/26/opinion/bahrain-a-brutal-ally.html [http://perma.cc/ 8XKA-GF5D].

189 Nanda, supra note 167, at 13-16.

190 Ibrahim Sharqieh, The Price of Abandoning Yemen, N.Y. TIMES (Sept. 22, 2014), http://www.nytimes.com/2014/09/23/opinion/the-price-of-abandoning-yemen.html?_r=0 [http://perma.cc/X4YA-A6RZ].

191 Yassin al-Haj Saleh, A Syrian's Cry for Help, N.Y. TIMES (Sept. 10, 2013), http://www.nytimes.com/2013/09/10/opinion/a-syrians-cry-for-help.html [http://perma. cc/G4HR-VF42].

192 Anthony Shadid, Egyptian Military Dissolves Parliament, N.Y. TIMES (Feb. 13, 2011), http://www.nytimes.com/2011/02/14/world/middleeast/14egypt.html?_r=0 [http:// perma.cc/8MYX-VHKD].

193 Jeremy M. Sharp, Cong. ReSEArCh SERV., RL33003, Egypt: BaCKGround AND U.S. RELATIONS 27 fig.8, 28 tbl.1 (2015) (outlining U.S. foreign aid to Egypt from 1981 to 1997 in Table 1 and from 1998 to 2011 in Figure 8). In the years after the end of the Mubarak era, the United States has been providing Egypt with approximately $\$ 1.55$ billion annually in foreign aid. Id. at 25-27. 
much U.S. aid as does Israel (at a ratio of two to three), roughly $\$ 2$ billion annually. ${ }^{194}$ Although such a payment appears benign, it helped Mubarak's dictatorial regime stay in power as did receiving "full American backing for across nearly three decades." 195

Mubarak subjected not only Muslim Brotherhood members but also dissidents of all ideological leanings to routine arrest, torture, and lengthy imprisonment. ${ }^{196}$ In the last ten years of his regime, " $10[-] 15,000$ [Muslim Brotherhood] members [on average] were tortured on a yearly basis. ..." 197 His policies ultimately led most of the Egyptian people to dislike, if not hate, President Mubarak. ${ }^{198}$ The huge daily protests in Tahrir Square ultimately helped end his regime. ${ }^{199}$ After resigning on February 11, 2011, Mubarak was tried

194 Agreement on the Framework for Peace in the Middle East, Egypt-Isr., Sept. 17, 1978, 17 I.L.M. 1466, 1466-69 (showing these are the Camp David Accords); Special International Security Assistance Act of 1979, 22 U.S.C. $\S \S 3401-3408$ (2009). The Accords do not expressly require the United States to provide aid to the parties, but it was generally understood that "sizable aid" would be forthcoming. CAROL LANCASTER, Foreign Aid: Diplomacy, DeVelopment, Domestic Politics (2007); JeREMy M. Sharp, Cong. Research Serv., RL33222, U.S. Foreign Aid to Israel 28 n.92 (2012) (noting that "the Egyptian government claims that a 3:2 ratio between Israel and Egypt was established during the negotiations"). Economic aid, however, was reduced by $\$ 400$ million starting in 2008. J. Scott Carpenter, The Future of U.S. Assistance to Egypt, WASH. INST. FOR NEAR E. POL'y (Aug. 21, 2008), http://www.washingtoninstitute.org/policyanalysis/view/the-future-of-u.s.-assistance-to-egypt [http://perma.cc/X6L6-EDEY]. The $\$ 1.3$ billion in military assistance remained. Id.

195 Lloyd C. Gardner, The RoAd to TAhrir Square 1 (2011).

196 Matthew Cole \& Sarah O. Wali, Egypt's Torture Victims Describe Beatings, Electroshock, Rape Threats, ABC NEws (Feb. 3, 2011), http://abcnews.go.com/ Blotter/egypts-torture-victims-describe-beatings-electroshock-rape-threats/story?id=1282 1831 [http://perma.cc/DZY7-3VLU]; see also Denis J. Sullivan \& Kimberly JONES, Global SECURity Watch-Egypt: A ReFERENCE HANDBOOK 38-39 (2008) (“Torture in Egypt is a widespread and persistent phenomenon.").

197 M. Cherif Bassiouni, Egypt Update No. 24, M. ChERIF BASsiouni (Oct. 31, 2013), http://mcherifbassiouni.com/wp-content/uploads/Egypt-Update-24.pdf [http://perma.cc/ D7M5-SMZB] ("[T]ens of thousands" were tortured "during the thirty-year Mubarak regime....”); see also M. Cherif BAssiouni, The Shari’a AND Islamic CRIMINAL Justice in Time of War AND Peace 281 (2014) (discussing the violence inherent in military campaigns).

198 The widely viewed fraudulent 2010 parliamentary elections also contributed to Mubarak's downfall. See Sahar F. Aziz, Revolution Without Reform? A Critique of Egypt's Election Laws, 45 GEO. WASH. INT'L L. REV. 1, 30 (2013) (citations omitted).

199 Kareem Fahim \& Mona El-Naggar, Violent Clashes Mark Protests Against Mubarak's Rule, N.Y. TIMES (Jan. 25, 2011), http://www.nytimes.com/2011/01/26/ world/middleeast/26egypt.html?pagewanted=all [http://perma.cc/J42R-QFSE]. 
and convicted of murder, embezzlement, and other charges. ${ }^{200}$ The murder conviction was later reversed and Mubarak was given a new trial, but he was sentenced to three years for embezzlement. ${ }^{201}$ The conviction for embezzlement was later reversed on procedural grounds. $^{202}$ Less than eighteen months after the coup, all pending charges against him were dismissed. ${ }^{203}$ But he was later convicted again and resentenced to three years for embezzlement. ${ }^{204}$ In June 2015, the Egyptian Court of Cassation, an appellate tribunal,

200 Edward Yeranian, Mubarak Convicted of Embezzlement, VOA News (May 21, 2014), http://www.voanews.com/content/egypts-ousted-president-convicted-of-embezz lement/1919064.html [http://perma.cc/WCZ9-BXPK].

201 Profile: Hosni Mubarak, BBC (Aug. 22, 2013), http://www.bbc.com/news/worldmiddle-east-12301713 [http://perma.cc/CGU5-QTYD]; see, e.g., Tony Blakely, ShortLived Shibboleth of a Moderate Egypt, WASH. TIMES (Dec. 5, 2011), http:// www.washingtontimes.com/news/2011/dec/5/short-lived-shibboleth-of-a-moderate-egyp $\mathrm{t}$ [http://perma.cc/P56L-8AVG] (discussing the misconception that there is a new Egyptian era and the democracy movement); Frank Gaffney Jr., Obama Pressure Leads to Predictable Fiasco, WASH. TIMES (Dec. 5, 2011), http://www.washingtontimes.com/ news/2011/dec/5/short-lived-shibboleth-of-a-moderate-eg-72840059 [http://perma.cc/ SLK7-FUXQ] (discussing how the Muslim Brotherhood is in control of Egypt after the elections); David D. Kirkpatrick, Mubarak Gets 3 Years for Embezzlement and His Sons Get 4, N.Y. TIMES (May 21, 2014), http://www.nytimes.com/2014/05/ 22/world/middleeast/hosni-mubarak-trial.html [http://perma.cc/RTE9-4RSW] (discussing Mubarak's embezzlement). Mubarak has already served the three-year sentence on embezzlement. David D. Kirkpatrick \& Merna Thomas, Egyptian Judges Drop All Charges Against Mubarak, N.Y. TIMES (Nov. 29, 2014), http://www.nytimes.com/ 2014/11/30/world/hosni-mubarak-charges-dismissed-by-egyptian-court.html [http:// perma.cc/FP4L-9X6U] (discussing the decision to drop charges against Mubarak). He has been serving the three-year sentence primarily at a highly regarded military hospital. Egypt's Hosni Mubarak Jailed for Embezzlement, BBC (May 21, 2014), http://www.bbc.com/news/world-middle-east-27499325 [https://perma.cc/XC3S-S7Y8].

202 David D. Kirkpatrick, Egyptian Judge Voids Mubarak's Last Standing Conviction and Orders Retrial, N.Y. TIMES (Jan. 13, 2015), http://www.nytimes.com/2015/ 01/14/world/middleeast/hosni-mubarak-conviction-overturned.html?r=0 [http://perma.cc/ 2Y6S-2PH8]. Similarly, an Egyptian court acquitted Mubarak's infamous interior minister of defense "of the last of several charges that have kept him behind bars." David D. Kirkpatrick, Court Clears Mubarak Official, N.Y. TiMES (Feb. 24, 2015), http:// www.nytimes.com/2015/02/25/world/middleeast/egypt-court-clears-mubarak-official-ha bib-el-adly.html [http://perma.cc/3J2H-HF8A].

203 Kirkpatrick \& Thomas, supra note 201. But see Bassiouni, Egypt Update No. 24, supra note 197 (questioning the legality of Mubarak's conviction on a theory of command responsibility not recognized in Egyptian law outside of the law of war).

204 Mubarak Sentenced to Three Years in Jail for Corruption, AL JAZEERA (May 9, 2015), http://www.aljazeera.com/news/2015/05/150509102401084.html [http://perma.cc/ EW2N-KN5V]. 
ordered Mubarak to stand for a third trial on the murder charges. ${ }^{205}$

\section{The Egyptian Elections Stemming From the Arab Spring}

The Presidential and Parliamentary elections that followed Mubarak's resignation, unfortunately, reflect the consequences of decades of dictatorial rule. For most of Egypt's history, including the years following the Officers Revolt of 1952, opposition political parties had been banned, dissent had been prohibited, and the press and other electronic media had been reined in. ${ }^{206}$ The only effective opposing political organization during the rule of Nasser, Sadat, and Mubarak was the Muslim Brotherhood. ${ }^{207}$ Although under Mubarak the Muslim Brotherhood had to put up nominally "independent" candidates for public office, ${ }^{208}$ the Brotherhood knew how to run political campaigns, had years of practice doing so, and were successful in getting their followers out to vote. ${ }^{209}$

205 Egypt: Mubarak to Be Retried over Killings of Protesters, BBC (June 3, 2015), http://www.bbc.com/news/world-middle-east-33003424 [http://perma.cc/3BVZ-78P5]; Merna Thomas \& Kareem Fahim, Third Trial Is Set for Mubarak in Killing of Egyptian Protesters, N.Y. TIMES (June 4, 2015), http://www.nytimes.com/2015/06/05/ world/middleeast/third-trial-is-set-for-mubarak-in-killing-of-egyptian-protesters.html?ref $=$ topics $[\mathrm{http}: / /$ perma.cc/VM2Q-KYWY].

206 See Don Peretz, The Middle East Today 240 (1994); Khaled Diab, Egypt's Heavily Censored Media Continues to Take on Regime, GUARDIAN (Feb. 9, 2012), http://www.theguardian.com/commentisfree/2012/feb/09/arabic-press-freedom-censorsh ip [http://perma.cc/GK55-HWCC] (discussing censored Media in Egypt); Patrick Kingsley, Egypt's Police Seek Ability to Monitor Social Media for Signs of Dissent, GUARDIAN (June 2, 2014), http://www.theguardian.com/world/2014/jun/02/egypt-policemonitor-social-media-dissent-facebook-twitter-protest [http://perma.cc/6MZX-7N8K] (discussing IT systems being asked to provide system which scans Facebook and Twitter for profanity, insults and incitements to protest). As M. Cherif Bassiouni notes, the Arab Spring brought about incomplete regime change. M. Cherif Bassiouni, Egypt Update Number 15, Chronicles of Egypt's Revolution, M. CHERIF BASSIOUNI (May 3, 2012), http://mcherifbassiouni.com/wp-content/uploads/Egypt-Update-15.pdf [http://perma.cc/ T56Q-72HT] ('In reality, Egypt's 'Revolution' was a partial regime change. It brought down Hosni Mubarak's presidency and the rule of his oligarchy, but it did not remove the military regime which has existed in Egypt since July 1952.").

207 See Egypt's Muslim Brotherhood Promotes Moderate Path, BBC (Feb. 20, 2011), http://www.bbc.com/news/world-middle-east-12504820 [http://perma.cc/DM8J-WGLQ] (saying Brotherhood was savvy in its handling of protests and is assumed to be one of the best organized and most popular opposition movement).

208 See Aziz, supra note 198, at 32-33.

209 Nicholas D. Kristoff, Democracy in the Brotherhood's Birthplace, N.Y. TIMES (Dec. 11, 2011), http:/www.nytimes.com/2011/12/11/opinion/Sunday/kristofDemocracy-in-the-Muslim-Brotherhoods-Birthplace.html [http://perma.cc/8XJK-SEM5]; see also M. Cherif Bassiouni, Egypt Update Number 25, M. ChERIF BAssiouni (Dec. 7, 
On the other hand, the young secular leaders of Egypt's Arab Spring had no such experience, had no long standing organization behind them, and had less ability to assure that their followers would make it to the polls. ${ }^{210}$ Furthermore, the main opponent to Muhammad Morsi, the Muslim Brotherhood candidate, was Ahmed Shafik, a former prime minister in the widely despised Mubarak regime. ${ }^{211}$ Consequently, a significant number of the secularists never turned out to vote. ${ }^{212}$ So although the young secularists led the Arab Spring and were more responsible for deposing Mubarak than any other political group, ${ }^{213}$ the Muslim Brotherhood ended up winning the first presidential election. ${ }^{214}$ The Muslim Brotherhood also polled well in the upper house of parliament (the Shura Council) and achieved close to a majority in the lower house (the People's Assembly). ${ }^{215}$

2013), http://mcherifbassiouni.com/wp-content/uploads/Egypt_Update_No._25.pdf [http://perma.cc/XFC4-VADZ] ("[The Egyptian military] were too hasty in allowing the legislative and presidential elections to take place at a time when it was clear that the secular democratic forces were disorganized while the Islamists were organized.”).

210 See Bassiouni, supra note 185, at 152.

211 Id. at 151.

212 About 52 percent of the registered voters exercised their franchise in the presidential elections of June 2012. Approximately 800,000 voters deliberately made "void" ballots, displaying their dislike of both candidates. See id.

213 Ashraf Khalil, As Egypt's Islamists Cement Their Rule, Can Secularists Reclaim the Revolution?, TIME (Sept. 4, 2012), http://world.time.com/2012/09/04/as-egyptsislamists-cement-their-rule-can-secularists-reclaim-the-revolution [http://perma.cc/JL7SXKWK]; see also Shadi Hamid, How Egypt's Muslim Brotherhood Will Win, ForeIGN POL'Y (Nov. 3, 2011), http://foreignpolicy.com/2011/11/03/how-egypts-muslimbrotherhood-will-win [http://perma.cc/DXM7-6GBM] (discussing the education, discipline, and popularity of the Muslim Brotherhood).

214 Muslim Brotherhood-Backed Candidate Morsi Wins Egyptian Presidential Election, Fox NEws (June 24, 2012), http://www.foxnews.com/world/2012/06/24/egyptbraces-for-announcement-president [http://perma.cc/3QFG-5XJ3].

215 Leila Fadel, Muslim Brotherhood's Political Party Consolidates Power in Egyptian Parliament, WASH. Post (Feb. 28, 2012), https://www.washingtonpost.com/ world/middle_east/muslim-brotherhoods-political-party-consolidates-power-in-parliame nt/2012/02/28/gIQA70sMgR_story.html [https://perma.cc/R3ZR-WZW5]. The Brotherhood's Freedom and Justice Party won 235 seats (47.2\%); the "hardline Salafist Nour party" won 121 seats (24.3\%), giving Islamists parties "around two-thirds of the seats in the assembly." Egypt's Islamist Parties Win Elections to Parliament, BBC (Jan. 21, 2012), http://www.bbc.com/news/world-middle-east-16665748 [http://perma.cc/52DKMHPC]. The Freedom and Justice party won $42 \%$ of the seats in the Shura Council, and was "easily" able to gain a majority with "support from conservative allies." Egypt's Shura Council and Constitution Panel 'Invalid,' BBC (June 2, 2013), 
From the Brotherhood's point of view, this was a well-deserved victory. They had been participating in essentially a rigged electoral process under the Mubarak regime for decades. ${ }^{216}$ After years of effort and after seeing so many of their candidates fraudulently denied public office, ${ }^{217}$ many of their members carted off to jail, and some to Mubarak's torture chambers, ${ }^{218}$ the Muslim Brotherhood won on both the executive and legislative levels. ${ }^{219}$

Yet the quality of their organization rather than the quality of their ideas probably led the Muslim Brotherhood to victory. Had the secularists a similar organization and party behind them and a different candidate to vote for, the result could very well have been different. ${ }^{220}$ Nevertheless, the Brotherhood did what many other political parties in their situation probably would do. President Morsi and his party proceeded to make a grab for power. They had the Brotherhood-dominated Parliament dictate an Islamist-oriented constitution to lock in their control. "[A] Muslim Brotherhood-led drafting panel... rushed the document through a Constituent Assembly in one day without significant public discussion."221 After successfully brokering a resolution of a dispute in Palestine,

http://www.bbc.com/news/world-middle-east-22745568 [http://perma.cc/FW4H-JYP8].

216 Profile: Hosni Mubarak, supra note 201.

217 See Aknur, supra note 144, at 6; Political HandBooK of THE World 2014, at 421 (Tom Lansford ed., 2014) (observing that the Mubarak regime blocked 90 percent of the Islamist candidates from running for election for the 52,000 positions in local elections in 2008).

218 Again stressing that "tens of thousands" were tortured "during the thirty-year Mubarak regime ....” Bassiouni, The Shari’a AND Islamic CRiminal Justice In Time OF WAR AND PEACE, supra note 197.

219 The Brotherhood won a majority in Parliament in September 2011 "after free and fair elections." Avi Shlaim, Israel, Palestine, and the Arab Uprisings, in THE NEw MidDLE East: Protest and Revolution in the Arab World 380, 397 (Fawaz A. Gerges ed., 2014).

220 See id. at 397.

221 Geoffrey Mock, Egypt in Crisis, U.S. Must Act for Human Rights, AMnESTy INT'L: Hum. RTS. Now Blog (Dec. 7, 2012, 6:21 PM), http://blog.amnestyusa.org/middleeast/egypt-in-crisis-u-s-must-act-for-human-rights [http://perma.cc/4DJC-9DNX]. The proposed constitution not only failed to protect freedom of expression or religion but also failed to guarantee women's rights, trade union rights, or economic, social or cultural rights. Id. "The draft constitution was . . approved by the Constituent Assembly only after liberals, Christians and others walked out in protest." Police Fire Tear Gas on AntiMorsi Protesters: 'This Is the Last Warning Before We Lay Siege,' COMMONDREAMS.ORG (Dec. 4, 2012), http://www.commondreams.org/headline/2012/12/04-3 [http://perma.cc/ 7RAS-XGHN]. 
Morsi took an unconstitutional leap: he declared himself as President outside the jurisdiction of the courts, permitting him to rule by decree. ${ }^{222}$

\section{The "Judicial Coup" and Human Rights Violations Committed under SCAF}

After Mubarak resigned but before the presidential and parliamentary elections, the Supreme Command of the Armed Forces ("SCAF") took over executive powers. ${ }^{223}$ Two days before the runoff in the 2012 presidential election, Egypt's Supreme Constitutional Court, made up of all Mubarak appointees, dissolved Egypt's first democratically elected house of parliament in which the Muslim Brotherhood together with other Islamic representatives had achieved a majority. ${ }^{224}$ The court also invalidated a parliament

222 President Morsi's constitutional decree states as follows:

[T] he Constitutional Declaration, laws and decrees issued by the president from June 30, 2012 until the constitution comes into effect and a new People's Assembly is elected will be final and self-executing, and not subject to legal challenge in any way or before any party. Such decrees cannot be challenged by suspension or annulment.

Egypt: Morsy Decree Undermines Rule of Law, Hum. RTs. WATch (Nov. 26, 2012) (emphasis added), https://www.hrw.org/news/2012/11/26/egypt-morsy-decreeundermines-rule-law [https://perma.cc/X5QJ-275A]; see also English Text of Morsi's Constitutional Declaration, AHRAM OnLINE (Nov. 22, 2012), http://english.ahram.org.eg/ News/58947.aspx [http://perma.cc/P5M2-5WD4] (giving the unofficial judicial translation). Morsi defended his usurpation of power on the ground that Mubarak appointed judges were preventing his government and Parliament from functioning. David D. Kirkpatrick \& Mayy el-Sheikh, Citing Deadlock, Egypt's Leader Seizes New Power and Plans Mubarak Retrial, N.Y. TiMES (Nov. 22, 2012), http://www.nytimes.com/2012/ 11/23/world/middleeast/egypts-president-morsi-gives-himself-new-powers.html [http:// perma.cc/B882-58D8]. Mubarak-appointed judges had also dissolved the Islamicdominated Parliament the year before. David D. Kirkpatrick, Blow to Transition as Court Dissolves Parliament, N.Y. TIMES (June 14, 2012), http://www.nytimes.com/ 2012/06/15/world/middleeast/new-political-showdown-in-egypt-as-court-invalidates-parl iament.html [http://perma.cc/TAT6-8UU7].

223 M. Cherif Bassiouni, Egypt Update Number 16, Chronicles of the Continued Egyptian Revolution of 25 January 2011, M. CHERIF BASSIOUNI (June 8, 2012), http://mcherifbassiouni.com/wp-content/uploads/Egypt-Update-16.pdf [http://perma.cc/ AP2B-E98T].

224 Tayyab Mahmud, A Judicial Coup?, Concurring OpInIOns (June 18, 2012), http://concurringopinions.com/archives/2012/06/a-judicial-coup.html [http://perma.cc/ 65ZW-PDB5]; see also Kirkpatrick, supra note 222. The court dissolved the parliament, reasoning that "[i]ndependent candidates had been disadvantaged by a clause restraining them to a quota that does not apply to members of political parties." Id. Chilibli Mallat, Saving Egypt's Supreme Court from Itself, AHRAM ONLINE (June 15, 2012), 
statute that prohibited senior Mubarak era officials from running for high office. ${ }^{225}$ A large number of Egyptians "suspected that SCAF had improperly meddled with the court's deliberations." 226 The court's decision had the effect of leaving legislative power in the hands of the military (which had already possessed executive power pending the election). ${ }^{227}$ According to the New York Times, "Many analysts and activists feared the decision was a step toward reestablishing a military-backed autocracy." ${ }^{228}$ One scholar likewise criticized the court:

The final yet no less troubling aspect of the decisions is that the SCC [Supreme Constitutional Court] looks as if it has done the full political bidding of the Ancien Régime. It finds its references in the military rulers 'constitutional declarations', it dissolves a seemingly adverse Parliament on grounds of inequality that miss[es] the forest for the trees, and it allows a former pillar of the Mubarak regime to go unchallenged. ${ }^{229}$

Aside from suspected complicity in that court's decision, the SCAF committed serious human rights violations, routinely using excessive force against civilians, arresting a large number of civilians on political grounds, subjecting them to military trials, and torturing or otherwise ill-treating a large number of prisoners. ${ }^{230}$

http://english.ahram.org.eg/NewsContentP/4/45009/Opinion/Saving-Egypt\%E2\%80\%9

9s-Supreme-Constitutional-Court-from-i.aspx [http://perma.cc/3S5F-AS2G].

225 Mahmud, supra note 224.

226 Aziz, supra note 198, at 4 (citing Kirkpatrick, supra note 222).

227 David Hearst \& Abdel-Rahman Hussein, Fury as Egypt's Parliament Is Dissolved in 'Judicial Coup,' GuARDian (June 15, 2012), http:// www.theguardian.com/world/middle-east-live/2012/jun/15/egypt-reels-judicial-coup-live [http://perma.cc/ANY4-TJSR]; Matthew Weaver \& Brian Whitaker, Egypt Reels from 'Judicial Coup,' GUARDIAN (June 15, 2012), http://www.theguardian.com/world/middleeast-live/2012/jun/15/egypt-reels-judicial-coup-live [http://perma.cc/9RJX-L4WX].

228 Kirkpatrick, supra note 222.

229 Mallat, supra note 224. But see Nathan Brown, The Egyptian Political System in Disarray, CARnegie Endowment FOR InT'L PeACE (June 19, 2012), http://carnegieendowment.org/2012/06/19/egyptian-political-system-in-disarray [http:// perma.cc/5PLX-YPSM] (suggesting that characterizing the Supreme Constitutional Court as "Mubarak Appointees" is "accurate but sometimes misleading"; Brown indicates that the court has had some "independence... [and] is actually a diverse body"). The Brotherhood's party had won 100 of its 235 "by running candidates as independents." Refugee Review Tribunal, Egypt Political Update 3 (2012).

230 AMNESTy INT'L, EGYPT: ROADMAP TO REPRESSION 5-6 (2014), http://www.amnesty.org/en/documents/MDE12/005/2014/en [http://perma.cc/U8ZTVET6]; see also Egypt: Morsy Law Invites Military Trials of Civilians, HUM. RTS. WATCH 


\section{E. Human Rights Violations under the Morsi Administration}

President Morsi's assuming office was also accompanied by human rights violations. ${ }^{231}$ In January 2013, there were violent clashes in Port Said, leaving over forty protesters dead, most at the hands of the Security Forces. ${ }^{232}$ Instead of calling for an investigation, President Morsi, presumably trying to curry favor with the military and the other security forces, essentially made them immune from prosecution or any other disciplinary action..$^{233}$ The Constitution that he and the Brotherhood rushed through parliament failed to respect woman's rights or the rights of religious minorities. ${ }^{234}$ The Islamic dominated parliament also attempted to

(Dec. 11，2012), https://www.hrw.org/news/2012/12/10/egypt-morsy-law-invitesmilitary-trials-civilians [https://perma.cc/8JWG-NTXC] (noting that the SCAF Justice Minister issued a decree on June 13, 2012, authorizing the military to arrest civilians and for them to be tried in military tribunals). On June 26, 2013, Egypt's high administrative court - the Council of State - annulled the justice minister decree. Id.; see also Bassiouni, Egypt Update No. 24, supra note 197 (observing that the Security Forces and the police used "excessive force" against demonstrators protesting any possible assurances by the Muslim Brotherhood in making the Army's privileges beyond question).

231 See, e.g., Egypt Activist Given 6 months for Insulting Morsi: AFP, GLOBAL Post (June 3, 2013), http://www.globalpost.com/dispatch/news/afp/130603/egypt-activistgiven-6-months-insulting-morsi-1 [http://perma.cc/RGS3-CE4D] (reporting youth activist sentenced to six months in prison for calling Morsi "a criminal and murderer"); Egyptian Satirist Faces Arrest for 'Insulting' Islam, President, VOA NEws (Mar. 30, 2013), http:// www.voanews.com/content/egyptian-satirist-faces-arrest-for-insulting-islam-president/1 631764.html [http://perma.cc/7USV-GLF8] (reporting that an arrest warrant was issued for TV personality Bassem Youssef); Hamza Hendawi, Egypt's Top Prosecutor Issues Arrest Warrants for 5 Prominent Activists over Latest Violence, CANADIAN PRESS (Mar. 25, 2013), http://bigstory.ap.org/article/egypt-activists-be-questioned-over-violence [http://perma.cc/PJ2V-8AR5] (giving example of warrants being used as an intimidation campaign).

232 Maggie Michael, Egypt's Morsi Considering Giving Military Control of Port Said, CTV NEwS (Mar. 5, 2013), http://www.ctvnews.ca/world/egypt-s-morsi-consideringgiving-military-control-of-port-said-1.1181756\#ixzz3F75i11OY [http://perma.cc/AGZ7ZESV]; see also Abigail Hauslohner, In Port Said, New Opposition to Egypt's Morsi, WASH. POST (Feb. 3, 2013), https://www.washingtonpost.com/ world/middle_east/in-portsaid-new-opposition-to-egypts-morsi/2013/01/28/9844f84a-698d-11e2-95b3-272d604a1 0a3_story.html [https://perma.cc/TW7C-AU9L] (reporting 54 people killed).

233 AMNESTY INT'L, supra 230, at 6.

234 Id. President Morsi also issued a law [Law No. 107 of 2012] on December 9, 2012, authorizing the military to arrest civilians and "to refer them to military courts until results are announced in the December 15[, 2012]" constitutional referendum. Egypt: Morsy Law Invites Military Trials of Civilians, supra note 230. This law ignored the Council of State decree of June 26, 2013, which prohibited military enforcement of civil law. Id.; see also Nanda, supra note 167, at 8-12 (discussing some of the Morsi regime's 
pass statutes to limit freedom of association and assembly. ${ }^{235}$ Furthermore, his government failed to take action against the men who sexually attacked women in or near Tahrir Square during the protests. ${ }^{236}$

In addition, some Muslim Brotherhood members engaged in violence against their political opponents. ${ }^{237}$ Some riots and protests turned bloody. Human Rights Watch ("HRW") noted that Muslim Brotherhood members detained forty-nine anti-Morsi protesters outside the presidential palace on December 5, 2012.238 The Egyptian Security Forces failed to intervene. These detentions "followed armed clashes that resulted in the deaths of [ten] people, mostly Muslim Brotherhood members, and injuries to 748 more, according to the Health Ministry." 239 Troubling, according to HRW, was President Morsi's characterizing the protesters as paid informants instead of demanding an independent investigation of both events. ${ }^{240}$ During Morsi's regime, there were also more

abuses of power)

235 AMNESTY INT'L, supra note 230, at 6.

236 Despite the coup and the Egyptian authorities' attacks, the Brotherhood apparently still has attempted to protest peacefully rather than resorting to violence. "In their strategy of confrontation, the MB have tried to resort to peaceful demonstrations and protests as a way of showing not only to Egyptians but to the international community that they are engaging in the reasonable exercise of the right to freedom of expression and assembly." Bassiouni, Egypt Update Number 25, supra note 209. Nonetheless, sometimes violence is resorted to. Id.; see also Egypt: Morsi Loyalists Vow to Keep Up 'Peaceful' Protest, BBC (July 11, 2013), http://www.bbc.com/news/world-middle-east-23274632 [http://perma.cc/ GH8S-T4NN] (talking about the pledge for peaceful protests after 50 Morsi loyalists were killed in clashes with the army).

237 Abdel-Rahman Hussein, Muhammad Morsi Calls for Dialogue in Attempt to Quell Egypt's Anger, GUARDIAN (Dec. 7, 2012), http://www.theguardian.com/world/ 2012/dec/06/mohamed-morsi-egypt [http://perma.cc/K97E-TERN] (reporting that 350 persons were injured in fights with rocks and firebombs between Morsi supporters and opponents and that the police failed to intervene when opponents burned down the Cairo office of the Muslim Brotherhood); see also Press Release, Human Rights Watch, EgyptInvestigate Brotherhood's Abuse of Protesters-Prosecutor Should Examine Authorities' Role in Unlawful Detention, Mistreatment (Dec. 12, 2012), https://www.hrw.org/news/ 2012/12/12/egypt-investigate-brotherhoods-abuse-protesters [https://perma.cc/Z37YC8BN]; Shlaim, supra note 219.

238 Press Release, Human Rights Watch, supra note 237. The events of December 5, 2012, form the basis for the capital charges that have been brought against President Morsi. Professor Bassiouni argues that the charges are "on their face broad and vague." Bassiouni, Egypt Update Number 25, supra note 209.

239 Press Release, Human Rights Watch, supra note 237.

240 Id. 
criminal prosecutions for blasphemy as well as increased attacks on Coptic Christians and Shia Muslims. ${ }^{241}$

Some have pointed to the "trauma" induced by the Morsi regime and have criticized Morsi for trying "to change Egyptian identity." 242 Others have objected to President Morsi asserting ever increasing power while he "mismanaged the country, g[ave] a monopoly on decision making to the Muslim Brotherhood and his Islamist allies, and encroached on the judiciary."243 Still others stressed his calling a referendum on a constitution that "undermines basic freedoms and violates universal rights." 244 Furthermore, some believe that the Muslim Brotherhood merely tagged on to the Arab Spring, and, therefore, was an undeserving recipient of the political opening that the young secularists responsible for the Arab Spring made possible. ${ }^{245}$

On the other hand, the Muslim Brotherhood generally had kept its pledge to renounce violence. ${ }^{246}$ As Avi Shlaim observed, Morsi

241 AMNESTY INT'L, supra note 230, at 6.

242 Maha Yahya, Choosing Security and Freedom in Egypt, CARnEGIE MidDle E. CTR. (July 1, 2014), http://carnegie-mec.org/2014/07/01/choosing-security-and-freedomin-egypt/hexr [http://perma.cc/7CGT-KWZN]; see also Dennis B. Ross, Opinion, Islamists Are Not Our Friends, N.Y. TIMES (Sept. 11, 2014), http://www.nytimes.com/ 2014/09/12/opinion/islamists-are-not-our-friends.html [http://perma.cc/67LM-EHQS] (setting forth key principles of how America should move forward with Islamist nations).

243 Hamza Hendawi, Egypt's Opposition Criticizes President's Speech, HufFINGTON Post (June 27, 2013), http://www.huffingtonpost.com/huff-wires $/ 20130627 / \mathrm{ml}$ egypt/?m=true [https://perma.cc/HZ3M-9GZH].

244 Sarah El Deeb, Egypt Sets Date for Constitution Vote, Boston Globe (Dec. 2, 2012), https:/www.bostonglobe.com/news/nation/2012/12/02/egypt-president-sets-datefor-constitution-vote/gVbnsrqWw5ET0HhiqB18BK/story.html [https://perma.cc/9LDE3CWB] (quoting Nobel Peace laureate Muhammad el-Baradei); see also Morsi's Failure to Connect with People Caused His Downfall, MeHr News Agency (July 6, 2013), http://www.moqawamah.com/?a=content.id\&id=12923\&print=1 [http://perma.cc/4K6QHNQG] (observing that Morsi's impolitic tone and policy toward the opposition greatly contributed to his overthrow).

245 See Muqtedar Khan, Islam, Democracy and Islamism After the Counterrevolution in Egypt, 21 MiddLE E. POL'y 9, 75, 80 (2014).

246 Despite the coup and the Egyptian authorities' attacks, the Brotherhood apparently still have attempted to protest peacefully. Bassiouni, Egypt Update Number 25, supra note 209 ("In their strategy of confrontation, the MB have tried to resort to peaceful demonstrations and protests as a way of showing not only to Egyptians but to the international community that they are engaging in the reasonable exercise of the right to freedom of expression and assembly."). Nonetheless, sometimes violence ensues. Id.; see also Maggie Michael \& Sarah El Deeb, Bombings Rock Egyptian Capital, Killing 5 People, YAHOO! NEWS (Jan. 24, 2014), http://news.yahoo.com/bombings-rock-egyptian- 
"represents the moderate and modernist core of the Muslim Brotherhood that renounced violence decades ago." 247 Compared to other countries that underwent a military overthrow of democratic rule, the Morsi regime's abuses were far from extreme: "[The Morsi regime's] excesses fell well short of those of [Venezuela's Hugo] Chavez, or Chile's Salvador Allende; unlike [Thailand's] Shinawatra or [Argentina's] Perón, Morsi did not set up militias or establish death squads. Although his government failed to compromise with opponents and sought to concentrate its power, it made only modest attempts to impose its Islamic ideology on the country and did not seek to alter Egypt's capitalist economy, which was slowly sinking but not imploding. It preserved crucial foreign relationships with the United States and Israel."248

Seeing their Arab Spring revolution exploited by the Muslim Brotherhood, the secularists, however, went back to Tahrir Square to protest Morsi's and the Brotherhood's actions. ${ }^{249}$ The protests extended beyond the square to most parts of the country. The still failing Egyptian economy added to the Muslim Brotherhood's unpopularity. ${ }^{250}$ Massive demonstrations, like those resulting in Mubarak's overthrow, were now aimed at Morsi and the Brotherhood. The opposition movement claimed they had obtained twenty-two million signatures on a petition for Morsi to step down. ${ }^{251}$ The Egyptian military, which had been part of the Security

capital-killing-5-people-094759738.html [https://perma.cc/5HLW-64WP] (reporting that al-Qaeda-inspired group, Amnsar Beit al Maqdis, had claimed responsibility for other attacks but not this one, yet suggesting that some believed the Muslim Brotherhood, despite its denials, was behind the attack).

247 Shlaim, supra note 219.

248 Jackson Diehl, Egypt's Misguided Coup, WASH. Post (July 4, 2013), https://www.washingtonpost.com/opinions/jackson-diehl-egypts-misguided-coup/2013/0 7/04/64bd121c-e4b4-11e2-a11e-c2ea876a8f30_story.html [https://perma.cc/R67BT6P7].

249 Ahmed A. Namatalla \& Ahmed Khalil El-Sayed, Egypt Islamists, Secularists Clash at Tahrir Square Protests, BloOMBERG Bus. (Oct. 12, 2012), http://www.bloomberg.com/news/articles/2012-10-11/egypt-brotherhood-calls-for-prote stsprotests-at-camel-battle-acquittal [http://perma.cc/U2CN-FNHA].

250 "The millions of Egyptians who took to the streets were also protesting chronic gas and food shortages and a sinking economy." After the Coup: The U.S. Shouldn't Cut Off Aid to Egypt, WALL ST. J. (July 7, 2013), http://www.wsj.com/ news/articles/SB10001424127887324399404578583932317286550 [http://perma.cc/ 7NBN-XHZA].

251 Abigail Hauslohner, Egyptian Group Accuses U.S. of Backing Morsi on Eve of Nationwide Protest Rallies, WASH. Post (June 29, 2013), https://www.washington 
Forces that had put down the Brotherhood for decades, were likewise uncomfortable with the Brotherhood's rise to power. There is substantial evidence that the Egyptian military surreptitiously provided money and other resources to the antiMorsi protests preceding the military overthrow and played a significant role in orchestrating the anti-Morsi demonstrations. ${ }^{252}$

Furthermore, the military had vital economic interests at stake. Unlike the military branch in most other countries, Egypt's military also ran many major money-making enterprises in the country, holding from five to sixty percent of the country's economy. ${ }^{253}$ After Morsi's election, there had been calls for the military to be divested of these enterprises. ${ }^{254}$ The Morsi regime had been planning to develop an area along the Suez Canal, but had cut out the military from any economic participation in the over eight billion dollar project, the biggest in Egypt for the next twenty

post.com/world/middle_east/egyptian-group-accuses-us-of-backing-morsimorsi-on-eveof-nationwide-protest-rallies/2013/06/29/d64a1268-e0f9-11e2-a63e-8d9380ed1f738d938 0ed1f73_story.html [https://perma.cc/GD7V-U5XY].

252 Iraq: ISIS Announces Caliphate, BBC World SERviCe (June 30, 2014), http://www.bbc.co.uk/programmes/p021g1r5 [http://perma.cc/6ED5-8UNQ] (observing that one of the leaders of the protest movement was taking orders from the Egyptian military as early as March 2013); see also Hamza Hendawi, Disputes Between Morsi, Military Led to Egypt Coup, YAHOO! News (July 18, 2013), http://news.yahoo.com/disputes-between-morsi-military-led-egypt-coup-205809544.html [https://perma.cc/BTA6-CR37] (explaining that "the military had been planning for months to take greater control of the political reins in Egypt" and that "the military helped the Tamarod [opposition movement] from early on"); David D. Kirkpatrick, Recordings Suggest Emirates and Egyptian Military Pushed Ousting of Morsi, N.Y. TIMES (Mar. 1, 2015), http://www.nytimes.com/2015/03/02/world/middleeast/recordings-suggestemirates-and-egyptian-military-pushed-ousting-of-morsi.html [http://perma.cc/LYM2VG9P] (giving evidence that the Egyptian military supported the protests).

253 Abigail Hauslohner, Egyptian Military Expands Its Control over the Country's Economy, WASH. Post (Mar. 16, 2014), https:/www.washingtonpost.com/world/ middle_east/egyptian-military-expands-its-economiceconomic-control/2014/03/16/39508 b52-a554-11e3-b865-38b254d92063_story.html [https://perma.cc/X37D-7DD9]; see also Ahmed Morsy, The Military Crowds out Civilian Business in Egypt, CARNEGIE ENDOWMENT FOR INT'L PEACE (June 24, 2014), http://carnegieendowment.org/ 2014/06/24/military-crowds-out-civilian-business-in-egypt/hedq [http://perma.cc/3CNMU7RD] (detailing the historical role of the military in Egypt's economy and how it has grown).

254 See Pelin Cengiz, Egyptian Army Considered Economic Stakes in Coup, AL MONITOR (July 10, 2013), http://www.al-monitor.com/pulse/iw/politics/2013/07/egyptarmy-economic-interests-coup-morsi.html [http://perma.cc/9KD7-ZWKZ]. 
years. ${ }^{255}$ Some speculate that this omission may have contributed to the military's decision to overthrow him. ${ }^{256}$

\section{F. The Military Coup, the Military's Repression of the Muslim Brotherhood, and the U.S. Response}

By July 2013, the Egyptian military under General Abdul Fattah el-Sisi decided to carry out a coup d'état against the first democratically elected and the first civilian president of Egypt. ${ }^{257}$ The available evidence suggests that, at best, the Obama administration made a half-hearted stance against the military's coup. $^{258}$ El-Sisi says the United States ambassador asked him "to hold off 'for a day or two' before ousting" Muhammad Morsi, but claims he "had rebuffed the request." 259 The secularists likewise supported the coup, some calling it a legitimate impeachment of an unpopular ruler. ${ }^{260}$

255 Daria Solovieva, Suez Canal: Egyptian Military Takes Charge of Economic Development, INT'L BuS. TIMES (Apr. 3, 2014), http://www.ibtimes.com/suez-canalegyptian-military-takes-charge-economic-developmentdevelopment-1566638 [http:// perma.cc/GG52-T8GQ]. 255 .

256 See Hauslohner, supra note 253; Cengiz, supra note 254; Solovieva, supra note

257 Ben Wedeman et al., Coup Topples Egypt's Morsy; Deposed President Under “House Arrest," CNN (July 4, 2013), http://www.cnn.com/2013/07/03/world/meast/ egypt-protests/index.html [http://perma.cc/VSU4-N79F]. The Muslim Brotherhood dominated lower house of Parliament had been dissolved two days before the presidential elections by a Mubarak filled Egyptian Court. See Robert Mackey, Latest Updates on Electoral Turmoil in Egypt, N.Y. TIMES (June 14, 2012), http://thelede.blogs. nytimes.com/2012/06/14/latest-updates-on-electoral-turmoil-in-egypt/?module=Search\& mabReward=relbias\%3Ar.egypt/ [http://perma.cc/HSM6-GYFD].

258 See Paul Richter, Morsi's Ouster Fuels Debate on U.S. Policy on the Mideast, L.A. TimeS (July 5, 2013), http://www.latimes.com/world/middleeast/la-fg-us-egypt20130706-story.html [http://perma.cc/6BEE-YJ6S]; President Barack Obama, Statement on Egypt (July 3, 2013) ("The United States is monitoring the very fluid situation in Egypt, and we believe that ultimately the future of Egypt can only be determined by the Egyptian people.”); David D. Kirkpatrick \& Mayy El Sheikh, Morsi Spurned Deal, Seeing the Military as Tamed, N.Y. TIMES (July 7, 2013), http://www.nytimes.com/2013/07 /07/world/middleeast/morsi-spurned-deals-to-the-end-seeing-the-military-as-tamed.html [http://perma.cc/UE69-QS26] (describing Obama's attempts to urge Mr. Morsi to compromise with the opposition).

259 David D. Kirkpatrick, U.S. Sought Delay of Morsi’s Ouster, Egyptian Leader Says, N.Y. TIMES (May 7, 2014), http://www.nytimes.com/2014/05/07/world/middleeast/ussought-delay-of-morsis-ouster-egyptian-leader-says.html [http://perma.cc/6R4D-597X].

260 See Bassiouni, Egypt Update Number 25, supra note 209 ("I take the position that it was a military coup, but that it had popular legitimacy, and that it did go against formal 
The coup essentially put the military back in control of Egypt after the great move forward propelled by the Arab Spring. ${ }^{261}$ Upon returning to full power, the new military leadership decided to stamp out the Muslim Brotherhood, the most significant organization opposing Egypt's heretofore unbroken and oppressive military rule since the Officers' Revolt in $1952 .{ }^{262}$ On coming into power, the military installed Adly Mansour as "Interim President."263 First, a Mubarak-appointed court dissolved the Muslim Brotherhood and ordered its property confiscated. ${ }^{264}$

legality because Morsi had been duly elected - a position which the United States supported at the time; namely, that he was the duly elected president of Egypt. But millions took to the streets on June 30, 2013 against the MB, and there was also a petition prepared by the group Tamarrud (the group spearheading calls for the June 30 demonstrations) allegedly signed by 22 million people for his removal from office. There was no constitution in effect, though the 2012 Constitution had been approved by a public referendum, but it never went into effect. There was no way to legally impeach or remove the president, thus the conflict between popular legitimacy expressed in the streets and in the petition and formal legality expressed in the election of Morsi in 2012."). I am indebted to Professor Bassiouni for his deep, scholarly research and writing on Egypt. I respectfully disagree, nonetheless, with his argument about "popular legitimacy" as implicitly justifying the coup, however unpopular Morsi may have been. On other support for the coup, see David Francis, How the U.S. Helped Fund the Egyptian Coup, FISCAL TIMES (July 8, 2013), http://www.thefiscaltimes.com/Articles/2013/07/08/How-the-US-HelpedFund-the-Egyptian-Coup [http://perma.cc/E8HA-NXMJ] (citing Muhammad El Baradei, the former U.N. Nuclear Watchdog Head, and describing the United States refusal to call the situation in Egypt a coup). The extremely conservative, Al-Nur party, also supported the military's plan or roadmap after the coup. See Nervana Mahmoud, In Egypt Watch the Nour Party, AL Monitor (Jan. 6, 2014), http://www.al-monitor.com/pulse/originals/2014/ 01/egypt-nour-party-gathers-strength.html [http://perma.cc/FT97-7PRG] (describing Nour's approach following Morsi's election); Muhammad A. Arafa, Whither Egypt? Against Religious Fascism and Legal Authoritarianism: Pure Revolution, Popular Coup, or a Military Coup d'Etat?, 24 IND. INT'L \& COMP. L. REV. 859, 861 (2014) (claiming that Morsi and the Muslim Brotherhood were comparable to Hitler and the Nazi Party).

261 See Laura King \& Ingy Hassieb, Egyptian Court Bans Muslim Brotherhood, Orders Its Assets Confiscated, L.A. TIMES (Sept. 23, 2013), http:// articles.latimes.com/2013/sep/23/world/la-fg-wn-egypt-muslim-brotherhood-banned-201 30923 [http://perma.cc/DCR2-Z3Y9].

262 See id.; Profile: Egypt's Muslim Brotherhood, supra note 101 (describing the Muslim Brotherhood's organization since the Officers' Revolt in 1952).

263 David D. Kirkpatrick, 3 Jailed Journalists Deny Ties to Brotherhood in Egypt, N.Y. TIMES (Mar. 31, 2014), http://www.nytimes.com/2014/04/01/world/middleeast/ journalists-deny-ties-to-muslim-brotherhood-in-egypt.html [http://perma.cc/KQF8LUC2].

264 Id. The Egyptian Supreme Judicial Court banned the Brotherhood's political party as well, the Freedom and Justice Party. Kimberly Bennett, Court Bans Muslim Brotherhood's Political Wing, JURIST (Aug. 9, 2014), http://jurist.org/paperchase/2014/ 
Second, although the Brotherhood had renounced violence decades $\operatorname{ago}^{265}$ and had generally abided by that pledge, the new military government's cabinet declared the Muslim Brotherhood a terrorist organization. ${ }^{266}$ So just as the secular Egyptian government had done in 1948 and Nasser in 1954, the Egyptian military controlled government in 2013 banned the Muslim Brotherhood. ${ }^{267}$ Furthermore, Mansour dissolved the Shura Council, the Islamic dominated upper house of Parliament. ${ }^{268}$

Not satisfied with overthrowing the President and banning the Brotherhood, the military arrested and imprisoned virtually all the Brotherhood's leaders, including President Muhammad Morsi and the Brotherhood's highest spiritual leader Muhammad Badie. ${ }^{269}$

08/egypt-court-bans-muslim-brotherhood-political-wing.php [http://perma.cc/ZYV3DW22]; see also Egypt Dissolves over 100 NGOs for Brotherhood Ties, AswAT MASRIYA (Mar. 1, 2015), http://en.aswatmasriya.com/news/view.aspx?id=1341c702-807b-4874be35-5c2c5b446fab5c2c5b446fab [http://perma.cc/BB7S-8DMD] (noting that Egypt banned 119 Non-Governmental Organizations (NGOs) on the ground they had "ties with the Muslim Brotherhood").

265 Aknur, supra note 144, at 10.

266 Egypt Declares Muslim Brotherhood a Terrorist Organization, GUARDIAN (Dec. 25, 2013), http:/www.theguardian.com/world/2013/dec/25/egypt-declares-muslimbrotherhood-terrorist-group [http://perma.cc/V9M6-CM9A]; see also Egypt: Terrorist Tag Politically Driven, HuM. RTS. WATCH (Dec. 28, 2013), https://www.hrw.org/ news/2013/12/28/egypt-terrorist-tag-politically-driven [https://perma.cc/8HP4-HULR] (describing the Egyptian government's designation of the Muslim Brotherhood as a terrorist organization); Zachary Laub, Egypt's Muslim Brotherhood, CounCIL ON FOREIGN REL., http://www.cfr.org/egypt/egypts-muslim-brotherhood/p23991 [http://perma.cc/ W93K-LSHP] (last updated Jan. 15, 2014) (describing the Muslim Brotherhood's history in Egypt).

267 See ChOUEIRI, supra note 111, at 59-62 (discussing the early bans on the Brotherhood); Muslim Brotherhood, supra note 118 and accompanying text.

268 See Maggie Michael \& Tony Gabriel, Egypt's Islamist-Led Interim Parliament Dissolved, YAHOO! NEWS (July 5, 2013), http://news.yahoo.com/egypts-islamist-ledinterim-parliament-dissolved-151430576.html [http://perma.cc/3CJV-2CWM] ("The Shura Council is normally a largely powerless body that does not legislate. But under the presidency of the now toppled Muhammad Morsi, it took up lawmaking powers because the lower house had been dissolved previously by court order.").

269 The military immediately arrested and detained over 300 Muslim Brotherhood leaders, including Muhammad Morsi and Muhammad Badie, the Brotherhood's supreme religious leader. El-Sisi has decided that Morsi will not receive a trial in civilian courts, but will instead be tried by a military tribunal. Top Brotherhood Officials Referred to Military Trial, Mursi Not Among Them-State Agency, Aswat MaSRIYA (Feb. 17, 2015), http://en.aswatmasriya.com/news/view.aspx?id=a9baa3e6-8181-446b-94d9-a8753cbbbf5 7 [http://perma.cc/3Q9Z-B65B]. He is facing an ever-expanding list of charges. Mursi Appears in First Court Hearing of New Espionage Trial, AswAT MASRIYA (Feb. 15, 2015), 
The military regime initially charged Morsi with a capital offense for allegedly inciting violence and recently sentenced him to twenty years in a maximum security prison. ${ }^{270}$ After a mass trial, an Egyptian court sentenced Muhammad Badie to death. ${ }^{271}$ In that trial the court sentenced 682 other individuals (predominantly Muslim Brotherhood members) to death "in connection with the killing of a

http://en.aswatmasriya.com/news/view.aspx?id=605c9246-495f-4eff-ba70-442126b7317 e [https://perma.cc/8Q87-SQNF] ("[Morsi] faces an array of charges including inciting the killing of protesters outside the presidential palace during his tenure in December 2012, insulting the judiciary, escaping prison during the January 25 uprising in 2011, as well as facing a separate espionage case."); see also Martin Chulov \& Patrick Kingsley, Egypt Prepares for Backlash as Morsi Allies Reject New Regime, GuARDIAN (July 5, 2013), http://www.theguardian.com/world/2013/jul/04/egypt-morsi-allies-regime [http://perma. cc/GJA7-T8NU] (describing a claim that Morsi insulted the presidency); New Egyptian Leader Vows Fresh Elections After 51 Killed, EXPRESS TrIBUNE (July 9, 2013), http://tribune.com.pk/story/574472/new-egyptian-leader-vows-fresh-elections-after-51killed/ [http://perma.cc/P9H2-BB5D] ("[T]he conservative Islamist al Nur party, which won almost a quarter of the votes in 2011-2012 parliamentary elections and had backed the army's overthrow of Mr. Morsi, said it was pulling out of talks on a new government in response to the massacre."); Freedom and Justice Party Condemns Erian Arrest in Coup Security Dawn Raid, IKHWANWeB (Oct. 30, 2013), http://www.ikhwanweb.com/ article.php?id=31390 [http://perma.cc/67GJ-8UMT] ("The FJP affirms that such repressive practices will not dissuade them from rejecting the brutal treasonous coup.").

270 David D. Kirkpatrick \& Merna Thomas, Egyptian Court Sentences Mohamed Morsi to 20 Years in Prison, N.Y. TIMES (Apr. 21, 2015), http:// www.nytimes.com/2015/04/22/world/middleeast/egypt-mohamed-morsi-sentenced.html [http://perma.cc/J4YF-57GG]. He was also subsequently charged with espionage and carrying out "terror attacks" in Egypt. Egypt's Muhammad Morsi Faces Spying Charges as Third Trial to Begin, NDTV (Feb. 16, 2014), http://www.ndtv.com/world-news/egyptsmohamed-morsi-faces-spying-charges-as-third-trial-to-begin-551008 [http://perma.cc/ G6RR-C4PF]; see also Laura King, New Charges Leveled Against Egypt's Deposed President Mohamed Morsi, L.A. TIMES (Dec. 18, 2013), http://www.latimes.com/ world/worldnow/la-fg-wn-egypt-morsi-new-charges-20131218-story.html [http:// perma.cc/BM3L-BJY4] (describing that the new charges stem from a prison break that occurred during the chaos of the 2011 uprising that drove longtime autocrat Hosni Mubarak from power). Morsi and the leaders in his administration are being held "in a secret location." Michael Mansfield \& Tayab Ali, Egypt's Military Will Not Get Away with Human Rights Abuses, GuARDIAN (Aug. 14, 2013), http://www.theguardian.com/ commentisfree/2013/aug/14/egpyt-military-human-rights-abuses [http://perma.cc/547KQBFA].

271 Tamer el-Ghobashy \& Dahlia Kholaif, Egyptian Court Upholds Death Sentence for Former President Mohammed Morsi, WaLL ST. J. (June 16, 2015), http:// www.wsj.com/articles/egyptian-court-upholds-death-sentence-for-former-president-moh ammed-morsi-1434450025 [http://perma.cc/TAW7-E5NV]. An Egyptian court did order the retrial of 36 who were sentenced to death. Court to Retry 36 over Post-Rabaa Dispersal Violence in Minya, ASWAT MASRIYA (Feb. 11, 2015), http:// allafrica.com/stories/201502111455.html [http://perma.cc/7P5M-2S3Z]. 
single police officer during a riot last summer." 272 A month earlier in a summary trial, the same Egyptian court had sentenced 529 individuals to death. ${ }^{273}$ Although most of these capital sentences are not expected to be enforced, ${ }^{274}$ Egypt carried out its first death sentence against an Islamic supporter of Morsi on March 7, 2015, ${ }^{275}$ and an Egyptian court promptly confirmed death sentences against thirty-seven defendants from the first mass trial, including against Badie $^{276}$ (only the intercession of Egypt's grand mufti has prevented

272 Jonathan Weisman, Military Aid for Egypt Loses Support in the Senate, N.Y. TIMES (Apr. 29, 2014), http://www.nytimes.com/2014/04/30/us/politics/egypt.html [http://perma.cc/5USQ-8W5P]. Other charges included attacking a police station, destroying public property, and seizing weapons. Egypt: ICJ Condemns Further Mass Death Sentences, INT'L COMMISSION JURISTS (Apr. 28, 2014), http://www.icj.org/egypticj-condemns-further-mass-death-sentences/ [http://perma.cc/4LNV-N3EJ].

273 Egypt Three Years on, Wide-Scale Repression Continues Unabated, AMNESTY INT'L (Jan. 23, 2014), http://www.amnesty.org/en/news/egypt-three-years-wide-scalerepression-continues-unabated-2014-01-23 [http://perma.cc/ZLJ6-WSAA] ("Since July 3, 2013, 1,400 people have been killed in political violence, most of them due to excessive force used by security forces. No proper investigation has been carried out into the deaths of more than 500 Morsi supporters when excessive force was used to disperse a sit-in at Rabaa al-Adawiya in August 2013. Not a single member of the security forces has been charged in connection with the incident which was a callous bloodbath on an unprecedented scale." (emphasis added)). One hundred eighty-three Muslim Brotherhood supporters were sentenced to death after being convicted of "playing a role in the killings of [sixteen] police officers in the town of Kardasa in August 2013 during the upheaval that followed the army's ousting of Islamist president Mohamed Morsi." Egyptian Court Sentences 183 Muslim Brotherhood Supporters to Death, GUARDIAN (Feb. 2, 2015), http://www.theguardian.com/world/2015/feb/02/egypt-muslim-brotherhood-supporterssentenced-death [http://perma.cc/S5SG-WBZB].

274 Death Penalty Worldwide, CORNELL L. SCH., http://www.deathpenalty worldwide.org/country-search-post.cfm?country=Egypt [http://perma.cc/4S8C-NT8Y] (last updated June 1, 2015) ("We believe there are at least 1,700 people under sentence of death [in Egypt], but no official figures are available due to intense state secrecy surrounding capital punishment. Amnesty International indicates that at least 1,413 death sentences were issued between 2007 and 2014. In recent years there has been a sharp increase in courts' use of capital punishment, with the number of death sentences jumping from 109 in 2013 to at least 509. Since the beginning of 2015, there have been reports of at least 354 death sentences, some of which may be reviewed or appealed. Executions in 2015 to date: $12 . ")$.

275 Kareem Fahim, Egypt Executes an Islamist Supporter of Ousted President, N.Y. TIMES (Mar. 7, 2015), http://www.nytimes.com/2015/03/08/world/middleeast/egyptexecutes-an-islamist-supporter-of-ousted-president.html [http://perma.cc/94V8-WQ78].

276 Yasmine Saleh \& Dominic Evans, Egypt Upholds Death Sentence on Brotherhood Leader, Nearly 200 Supporters, WALL ST. J. (June 21, 2014), https://www.washington post.com/world/egypt-upholds-death-sentence-on-brotherhood-leader-nearly-200-suppor ters/2014/06/21/43eca592-f98b-11e3-8aa9-dad2ec039789_story.html [https://perma.cc/ 
an execution from that trial). ${ }^{277}$ The court sentenced the remaining 492 individuals from that mass trial to twenty-five years imprisonment at hard labor. ${ }^{278}$

From the outset of the coup, the military brutally put down protests and demonstrations of the Muslim Brotherhood. ${ }^{279}$ Aside from arresting the Brotherhood's top leadership and rank and file who openly objected to Morsi's overthrow, the Security Forces five days later fired on hundreds who took part in a protest against Egypt's military coup. ${ }^{280}$ Over fifty people were killed and more than 400 injured. ${ }^{281}$ Less than two weeks later, the Security Forces killed seventy-four people, shooting many in "the head or the chest," suggesting an intent not to disperse peacefully but to kill. ${ }^{282}$

N6A4-FEFA]. In another case, Badie and his deputy Khairat al-Shater along with other Brotherhood leaders were sentenced to life in prison. Muslim Brotherhood Members Sentenced to Life in Prison, TIMES ISRAEL (Feb. 28, 2015), http:// www.timesofisrael.com/muslim-brotherhood-leaders-sentenced-to-life-in-prison/ [http:// perma.cc/RL9A-JYZU].

277 Kareem Fahim \& Merna Thomas, Key Cleric in Egypt Rejects Executions, N.Y. TIMES (Aug. 7, 2014), http://www.nytimes.com/2014/08/08/world/middleeast/key-clericin-egypt-rejects-executions.html [http://perma.cc/K4PA-LWFR] (noting that the religious leader's intercession seen as a rebuff to Egypt's military regime and to the courts). Nevertheless, Egyptian President, Abdel Fatah al-Sisi, promised changes in laws to allow for faster executions. Patrick Kingsley, Egyptian President "to Change Law to Allow Faster Executions,” GUARDIAN (June 30, 2015), http://www.theguardian.com/ world/2015/jun/30/egyptian-president-al-sisi-change-law-faster-executions-death-penalty [https://perma.cc/LTX6-PKYF].

278 Egypt: ICJ Condemns Further Mass Death Sentences, supra note 272. Both mass trials were held by the Minya Criminal Court. Id. Most were tried and sentenced in absentia: Of the 683 sentenced, only 80 individuals were under arrest. Id.

279 See sources cited supra note 273; SHARP, supra note 193; Eric Trager \& Gavi Barnhard, Brothers in Trouble?, FOREIGN AfF. (Sept. 24, 2014), https:// www.foreignaffairs.com/articles/egypt/2014-09-24/brothers-trouble [http://perma.cc/ XT3A-C3VD]; At Least Six Dead as Islamist Protesters Clash with Police in Cairo, GUARDIAN (July 17, 2015), http://www.theguardian.com/world/2015/jul/17/people-killedislamist-protest-cairo-egypt [http://perma.cc/KCC7-S5JT]; Egypt Court Condemns 9 to Death for Killing of Judge's Bodyguard, News24 (Sept. 7, 2015), http:// www.news24.com/Africa/News/Egypt-court-condemns-9-to-death-for-killing-of-judgesbodyguard-20150907 [http://perma.cc/T9HS-S72G].

280 Chris Hughes, Ahmed Assem: Chilling Video Shows Egyptian Photographer Filming Sniper as He Shoots Him, MIRROR (July 10, 2013), http://www.mirror.co.uk/ news/world-news/ahmed-assem-video-egyptian-photographer-2042649 [http://perma.cc/ 3Z7G-YP7B].

281 Id.

282 Kareem Fahim \& Mayy El Sheikh, Crackdown in Egypt Kills Islamists as They Protest, N.Y. TIMES (July 28, 2013), http://www.nytimes.com/2013/07/28/world/ 
On August 14, 2013, the Egyptian Security Forces frontally attacked Muslim Brotherhood protesters, killing, in a 12 hour deliberate assault, at least 600 and possibly as many as 1,000 persons in a sit-in, and wounding over 3,700 others. ${ }^{283}$ The government's onslaught against the Muslim Brotherhood is ongoing. Amnesty International reported that 1,400 people have been killed in the violence, most of them at the hands of Egyptian Security Forces, using "excessive force." 284

middleeast/egypt.html [http://perma.cc/7Q3Z-FP4N] ("The tactics—many were killed [by the Egyptian security forces] with gunshot wounds to the head or the chest-suggested that Egypt's security services felt no need to show any restraint.").

283 David D. Kirkpatrick, Hundreds Die as Egyptian Forces Attack Islamist Protesters, N.Y. TIMES (Aug. 15, 2013), http://www.nytimes.com/2013/08/15/ world/middleeast/egypt.html?ref=world [http://perma.cc/4YG8-SJ95] ("But the scale [of the Security Forces' attack] - lasting more than 12 hours, with armored vehicles, bulldozers, tear gas, birdshot, live ammunition and snipers - and the ferocity far exceeded the Interior Ministry's promises of a gradual and measured dispersal."); All According to Plan: The Rab'a Massacre and Mass Killings of Protesters in Egypt, HuM. RTS. WATCH (Aug. 12, 2014), https://www.hrw.org/report/2014/08/12/all-according-plan/rabamassacre-and-mass-killings-protesters-egypt [http://perma.cc/3Z7G-YP7B] ("The gravest incident of mass protester killings occurred on August 14, when security forces crushed the major pro-Morsy sit-in in Rab'a al-Adawiya Square in the Nasr City district of eastern Cairo. Using armored personnel carriers (APCs), bulldozers, ground forces, and snipers, police and army personnel attacked the makeshift protest encampment, where demonstrators, including women and children, had been camped out for over 45 days, and opened fire on the protesters, killing at least 817 and likely more than 1,000."); see also Ken Roth, Egypt's Tiananmen, Hum. RTs. WATch (Aug. 12, 2014), https://www.hrw.org/news/2014/08/12/egypts-tiananmen [http://perma.cc/3Z7G-YP7B] (arguing that the Rabaa dispersal was part of a pattern of cases across Egypt in which security forces used excessive force).

284 Amnesty InT'L, Egypt: Human Rights in CRisis: Systemic Violations AND IMPUNITY 6 (2014), https://www.amnesty.org/en/documents/mde12/034/2014/en/ [https://perma.cc/8Q24-W8JR]; Egypt Three Years on, Wide-Scale Repression Continues Unabated, supra note 273. Although one might expect the Muslim Brotherhood to react violently to the repressions, the New York Times reports that despite the coup regime's claims to the contrary, "there is no publically available evidence" that new violent presumably Islamist groups who have emerged after the coup and who have carried out attacks against businesses, utilities and the police have links to the Brotherhood. David D. Kirkpatrick, Egypt Arrests 75 in Connection with Recent Attacks, N.Y. TimES (Mar. 13, 2015), http://www.nytimes.com/2015/03/13/world/middleeast/egypt-arrests-75-inconnection-with-recent-attacks.html [http://perma.cc/P8YM-JHZ4]. Since the coup, there has been a significant rise in terrorist type attacks. See Merna Thomas \& David D. Kirkpatrick, Obscure Group Says It Set Off Blasts in Egypt, Raising Alarm, N.Y. TIMES (Feb. 27, 2015), http://www.nytimes.com/2015/02/27/world/middleeast/egypt-gizabomb-explosions.html [http://perma.cc/62ZA-T9PD] (describing a pattern of attacks on retail stores, including the Popular Resistant Movement's attack); Egypt Military Court Sentences 7 to Death on Charges Related to Terrorism, AHRAM OnLINE (Oct. 21, 2014), 
Refusing to restrict their fire to the Muslim Brotherhood, the post-coup military regime has banned all demonstrations it has not expressly approved, potentially muzzling not only the Brotherhood but all other groups ${ }^{285}$ seeking to protest the military's authority and policies. ${ }^{286}$ Furthermore, the military has referred over 800 civilians to military courts under an October 2014 decree by President elSisi. ${ }^{287}$

http://english.ahram.org.eg/NewsContent/1/0/113600/Egypt/0/Egypt-military-court-sente nces--to-death-on-charge.aspx [http://perma.cc/P4L6-KENS] (noting that President el-Sisi declared a state of emergency for three months in the Sinai Peninsula).

285 David D. Kirkpatrick \& Merna Thomas, Egyptian Media to Limit Criticism of Government, N.Y. TIMES (Oct. 26, 2014), http://www.nytimes.com/2014/10/27/world/ middleeast/egyptian-media-to-limit-criticism-of-government.html [http://perma.cc/ T5KL-YC22] (noting that Egypt sentenced twenty-three non-Islamist protesters to three years in prison for failing to obtain a permit to protest); see also David D. Kirkpatrick \& Merna Thomas, Egyptian Blogger Sentenced to 5 Years in Prison for Protest Role, N.Y. TiMES (Feb. 23, 2015), http://www.nytimes.com/2015/02/24/world/middleeast/bloggerwho-led-protests-is-given-a-five-year-sentence-in-egypt.html [http://perma.cc/FQ47DV9P] (noting that the secular blogger, Alaa Abd el Fattah, 33, was one of the best known faces of the Egyptian Arab Spring); Egypt: Lift Ban on Youth Opposition Group, HuM. RTS. WATCH (Apr. 30, 2014), https://www.hrw.org/news/2014/04/30/egypt-lift-banyouth-opposition-group [https://perma.cc/NLZ2-5B75] (describing an Egyptian court's ban on the activities of the April 6 Movement is a clear violation of citizens' rights to free association, peaceful assembly, and free expression).

286 Kirkpatrick \& Thomas, Egyptian Media to Limit Criticism of Government, supra note 285. The International Commission of Jurists observed that "[o]ther judges have been accused of forming an illegal group, 'Judges for Egypt,' which called for the return of the ousted President Morsi. Egypt: Military, Government and Politicized Judiciary Are Crushing Freedom of Expression, INT'L COMMISSION JURISTS (June 24, 2014), http:// www.icj.org/egypt-military-government-and-politicized-judiciary-are-crushing-freedomof-expression/ [http://perma.cc/8WUZ-GUBJ]. "They were referred to a disciplinary board for charges that include 'stirring sedition among the ranks of judges' and 'threatening public security." Id. The International Commission of Jurists also condemned the use of oppressive laws against peaceful protesters, observing that on June 11, 2014, "under Law no. 107 of 2013 on public meetings, processions and protests, the South Cairo Criminal Court convicted 25 individuals and sentenced them to 15 years imprisonment for participating in a demonstration in front of the Shura Council." Id. In a similar vein, the el-Sisi regime also failed to protect Coptic churches against Muslim Brotherhood members' attacks in the wake of the coup. Egypt-Mass Attacks on Churches - Christians Say Pleas for Protection Fell Largely on Deaf Ears, HuM. RTs. WATCH (Aug. 21, 2013), https://www.hrw.org/news/2013/08/21/egypt-mass-attacks-churches [http:// perma.cc/TT6C-8XDJ]. On the other hand, the el-Sisi government responded militarily to ISIS killing Coptic Christian hostages. Egypt Avenges Mass Beheadings, Strikes ISIS in Libya, Jerusalem Post (Feb. 16, 2015), http://www.jpost.com/Middle-East/Egyptavenges-mass-beheadings-strikes-ISIS-in-Libya-391164 [http://perma.cc/M8HU-JSVN].

287 See Egypt: Surge of Military Trials, HuM. RTS. WATch (Dec. 18, 2014), https://www.hrw.org/news/2014/12/18/egypt-surge-military-trials [http://perma.cc/ 
The Egyptian government has also shackled the press and generally denied the freedom of expression. Three Al Jazeera reporters were sentenced to seven to ten years in prison for publishing "false news." 288 After Egypt received intense international condemnation, ${ }^{289}$ Egypt's Court of Cassation in January 2015 ordered a retrial. ${ }^{290}$ After the journalists spent over a year in prison, the authorities released two of the journalists on bond and deported the third. On retrial, the remaining two were again convicted and sentenced to three years in prison. ${ }^{291}$ Twenty-two Egyptian journalists remain incarcerated. ${ }^{292}$ In addition, seventyfive Egyptian judges signed a petition on July 24, 2013, protesting the overthrow of President Morsi, dissolution of the Parliament's upper house (the Shura Council) and the closure of news media outlets. $^{293}$ All seventy-five judges were placed in disciplinary proceedings and referred for "criminal charges under the Penal code." 294 In August 2015, Abdel Fattah el-Sisi issued a new

\section{LMY-F7DW].}

288 For the full charges against the journalists, see Hany Georgy, Memorandum Concerning the Trial of Al-Jazeera Journalists, EGYPT ST. InFO. SERV. (July 14, 2014), http://www.sis.gov.eg/En/Templates/Articles/tmpArticleNews.aspx?ArtID=78769\#.VdU BrFO6fR0 [http://perma.cc/G5U8-P72R].

289 David D. Kirkpatrick, Egyptian Court Orders Release of 2 Al Jazeera Journalists, N.Y. TiMES (Feb. 12, 2015), http://www.nytimes.com/2015/02/13/world/middleeast/ egyptian-court-orders-release-of-2-al-jazeera-journalists.html [http://perma.cc/66Z55W98]; see also ICJ Joins in Call for Attention to Deteriorating Human Rights Situation in Egypt, INT'L COMMISSION JURISTS (Oct. 22, 2014), http://www.icj.org/icj-joins-in-callfor-attention-to-deteriorating-human-rights-situation-in-egypt/ [http://perma.cc/6KWSFFTC] (noting, among other human rights violations, Egypt's need for immediate and unconditional release of persons detained solely for peacefully exercising their rights to freedom of expression, assembly and association).

290 Kareem Fahim, Al Jazeera Journalists Sentenced to 3 Years in Prison in Egypt, N.Y. TIMES (Aug. 29, 2015), http://www.nytimes.com/2015/08/30/world/middleeast/aljazeera-journalists-sentenced-to-3-years-in-prison-in-egypt.html [http://perma.cc/VWU9F4LT].

291 Id.

292 Id.; Roy Greenslade, Four More Journalists Arrested in Egypt, Where 18 Are Already in Jail, GUARDIAN (July 7, 2015), http:/www.theguardian.com/media/ greenslade/2015/jul/07/four-more-journalists-arrested-in-egypt-where-18-are-already-injail [http://perma.cc/YC5T-X3J6].

293 Egypt: Military, Government and Politicized Judiciary Are Crushing Freedom of Expression, supra note 286.

294 Id. Many of the judges were given travel bans. Id. An Egyptian disciplinary court subsequently required forty-one judges to retire. See Egypt Sacks 41 Judges for Supporting the Brotherhood, EGYPT INDEP. (Mar. 14, 2015), http://www.egypt 
counterterrorism law that further restricts freedom of expression by expanding the government's surveillance powers and by penalizing journalists for contradicting official accounts of militant attacks. ${ }^{295}$

In the two years since the military regime overthrew President Morsi, "more than 40,000 people have been arrested." 296 The arrestees do include primarily Muslim Brotherhood members, but also journalists and secular, pro-democracy protesters. ${ }^{297}$ Furthermore "[t]orture and other ill-treatment of detainees remained routine and was committed with impunity." 298

On June 3, 2014, General el-Sisi won the "pro forma" presidential election; ${ }^{299}$ less than a majority of registered voters

independent.com/news/sources-egypt-sacks-41-judges-supporting-brotherhood [http:// perma.cc/FG96-G8H4]; David D. Kirkpatrick, Egypt Seizes Newspaper to Censor Article, N.Y. TIMES (Oct. 1, 2014), http://www.nytimes.com/2014/ 10/02/world/middleeast/egyptseizes-newspapers-to-censor-an-article.html [http://perma.cc/FZE6-Y2G7] ("[T]he censorship is another example of constriction of news media freedom since the military takeover in July 2013 that brought Mr. Sisi to power.”).

295 Kareem Fahim \& Merna Thomas, Egypt Widens Government Power with New Anti-Terrorism Law, N.Y. TIMES (Aug. 17, 2015), http://www.nytimes.com/2015/08/18/ world/middleeast/egypt-widens-government-power-with-new-anti-terrorism-law.html [http://perma.cc/WD7Z-TNKZ]; Egypt Imposes Anti-Terror Law That Punishes 'False' Reporting of Attacks, GUARDIAN (Aug. 17, 2015), http://www.theguardian.com/world/ 2015/aug/17/egyptian-president-ratifies-law-to-punish-false-reporting-of-terror-attacks [http://perma.cc/B78Z-DZU9].

296 Carol Morello, Kerry Visits Egypt as Its Repression Grows, Wash. Post. (Aug. 2, 2015), https:/www.washingtonpost.com/world/kerry-visits-egypt-to-strengthen-ties-as -repression-is-growing/2015/08/02/f59e9eaa-36d2-11e5-ab7b-6416d97c73c2_story.html [https://perma.cc/GFJ7-C68H].

297 Id.

298 Amnesty InT'L, AmNesty InTERnAtional Report 2014/15: The StATE OF the WORLD's HUMAN Rights 137 (2015), https:/www.amnesty.org/en/documents/ pol10/0001/2015/en/ [http://perma.cc/FW3H-NWX4]; see Jared Maslin, Human Rights Groups Fear for Rule of Law in Egypt After Lawyer Dies in Custody, GuARDIAN (Aug. 12, 2015), http://www.theguardian.com/world/2015/aug/12/human-rights-groups-fear-rulelaw-egypt-karim-hamdy-dies-police-custody [http://perma.cc/B68R-DZXE] (observing signs of torture in lawyer who died in police custody); 2,600 Reportedly Killed in 18 Months Since Overthrow of Mohamed Morsi, GuARDIAN (May 31, 2015), http://www.theguardian.com/world/2015/may/31/at-least-2600-reportedly-killed-in-egyp t-following-overthrow-of-mohamed-morsi [http://perma.cc/GJC7-HNWY] (noting that police stations are filled to $400 \%$ capacity and prisons to $160 \%$ and deaths of at least 36 in police detention); 3 Members of Egypt Council for Human Rights Say Arab Prison Report 'Distorts Reality,' AHRAM ONLINE (Sept. 2, 2015), http://english.ahram.org.eg/ NewsContent/1/64/139528/Egypt/Politics-/-members-of-Egypt-Council-for-Human-Righ ts-say-Aqr.aspx [http://perma.cc/L4JT-GB4A].

299 Mayy el Sheikh, Egypt: Sisi Wins with 97 Percent, N.Y. TimES (June 4, 2014), 
went to the polls to cast their ballots. ${ }^{300}$ But the legitimacy of the election had already been eroded by the military's overthrowing the freely and fairly democratically elected president, by banning the opposition party under the pretext of fighting terrorism, by imprisoning the overthrown President and Muslim Brotherhood leadership and charging them with capital offenses under an overbroad statute, and by extensively employing excessive, deadly force against Muslim Brotherhood protesters.

\section{International Law As a Guide to Counter-Terrorism Policy and Practice}

\section{A. The Emerging Norm Prohibiting Military Overthrow of Democratic Governments}

The international community has increasingly condemned military coups d'état against democratic governments. ${ }^{301}$ There is an evolving norm of customary international law rendering such overthrows unlawful. ${ }^{302}$ Some argue that no state responsibility arises from a coup, so the practical effect of the international community's declaration of illegality is more political and moral than firmly based on legal principle. ${ }^{303}$ On the other hand, often a large number of states have refused to recognize the military

http://www.nytimes.com/2014/06/04/world/middleeast/egypt-sisi-wins-with-97-percent. html [http://perma.cc/D6WX-3F5Z].

300 Id. ("[T] sought to prove he had a mandate to lead and less than the 52 percent who voted in the 2012 election won by Muhammad Morsi, whom Mr. Sisi overthrew last year.”). El-Sisi received 97 percent of the vote. Id.

301 Thomas M. Franck, The Emerging Right to Democratic Governance, 86 AM. J. INT'L. L. 46 (1992); see also Gregory H. Fox, Internationalizing National Politics: Lessons for International Organizations, 13 WIDENER L. REV. 265, 265 (2007) ("While human rights regimes had long discredited the idea that the international community should never be involved in matters of national politics, the move toward democratic legitimacy took intervention a giant step further."). On the other hand, the military overthrowing a dictatorial government may be legitimate. Ozan O. Varol, The Democratic Coup d'État, 53 HARV. INT'L. L.J. 291 (2012).

302 Franck, supra note 301, at 49-54. For an authoritative analysis of the requirements to establish a custom - sufficiently dense state practice and a recognition that the practice has crystallized into a legal obligation - see Military and Paramilitary Activities in and Against Nicaragua (Nicar. v. U.S.), Judgment, 1986 I.C.J. Rep. 14 (June 27).

303 Jean D'Aspremont, Responsibility for Coups d'Etat in International Law, 18 TUL. J. INT'L \& COMP. L. 451, 454-65 (2010). 
government coming into power. ${ }^{304}$ Sometimes, the United Nations has refused to give to the coup regime that state's seat if the United Nations, has condemned the overthrow of a democratically elected leader $^{305}$ and even has taken direct legal action against the coup government. $^{306}$ Sometimes, other international organizations similarly opposed such coups. ${ }^{307}$ Such refusals have both political and legal consequences. For example, a United States' statute prohibits the United States from providing any aid to a country "whose duly elected head of government is deposed by military coup or decree." 308

304 See, e.g., M.J. Peterson, Recognition of Governments Should Not Be Abolished, 77 AM. J. INT'L L. 31, 38 (1983) (citing the move to democratic legitimism by the five Central American Republics of Costa Rica, El Salvador, Guatemala, Honduras and Nicaragua in an additional protocol to their 1907 Treaty of Peace and Amnesty).

305 The U.N. General Assembly condemned the military overthrow of the first democratically elected President of Haiti. G.A. Res. 46/138, U.N. Doc. A/RES/46/138 (Dec. 17, 1991); see also Fox, supra note 301, at 268 (noting the U.N. Security Council's resolutions on restoring deposed government in Sierra Leone (as well as Aristede's)).

306 See, e.g., S.C. Res. 940, 94 (July 31, 1994) ("[The Security Council] authorizes Member States to form a multinational force under unified command and control and, in this framework, to use all necessary means to facilitate the departure from Haiti of the military leadership, consistent with the Governors Island Agreement, the prompt return of the legitimately elected President....”); U.N. GAOR, 63d Sess., 93d plen. mtg., U.N. Doc. A/10842 (June 30, 2009), http://www.un.org/press/en/2009/ga10842.doc.htm [http://perma.cc/VK6F-8KTJ] (condemning the Honduras coup d'état and demanding immediate, unconditional restoration of the democratically elected president).

307 See, e.g., Roland I. Perusse, Haitian Democracy Restored 1991-1995, at 2223 (1995) (condemning the overthrow of Haitian President Aristede and demanding his restoration as President).

308 See Foreign Operations, Export Financing, and Related Programs Appropriations Act of 1996, Pub. L. 104-107, 110 Stat. 704, 723. The Turkish Parliament, Afghan Senate, and Nigerian government condemned the Egyptian coup, but Secretary General Ban Kimoon merely called for the quick return to democratic rule. See, e.g., Turkish Parliament Condemns "Military Coup" in Egypt, ANADOLU Agency (July 4, 2013), http://www.aa.com.tr/en/rss/200438--turkish-parliament-condemns-egypts-military-coup [http://perma.cc/XKW7-GBMY] ("Turkish parliament's Human Rights Committee on Thursday issued a joint statement, condemning the military coup in Egypt.”); Senate Condemns Coup Against Mursi, PajhwoK Afghan News (July 7, 2013), http://www.pajhwok.com/en/2013/07/07/senate-condemns-coup-against-mursi [http:// perma.cc/3XQH-XNV9] ("The Senate on Sunday condemned the ouster of Egyptian president Mohammad Mursi as an act against international law and democratic norms, calling the move an insult to the public mandate."); Nigeria Condemns Egypt Coup, XiNHUA News AgENCY (July 5, 2013), http://big5.zlb.gov.cn/gate/big5/ news.xinhuanet.com/english/africa/2013-07/06/c_124966206.htm [http://perma.cc/ CQZ3-PD7G] ("The Nigerian government has condemned the military takeover in Egypt, saying that the unfortunate development is a gross violation of the Constitutive Act of the 
The overthrow of Mohammad Morsi resembles in some respects the overthrow of Haitian President Jean-Bertrand Aristede. In both cases, the military overthrew democratically elected presidents. ${ }^{309}$ In both cases, each president was the first democratically elected president in his country's history. ${ }^{310}$ In Egypt, Morsi was the first civilian ever to be the head of state. ${ }^{311}$ There are significant differences, however. The U.N. General Assembly condemned the military junta's ousting Aristede, and the Security Council, acting under Chapter VII, authorized the use of armed force to restore Aristede to power (which the U.S. military helped bring about). ${ }^{312}$ Neither the U.N. General Assembly nor the Security Council has condemned the Egyptian military's overthrowing Morsi. Perhaps the difference in the two leaders' popularity explains the different international reactions. Aristede was elected with sixty-seven percent of the popular vote ${ }^{313}$ whereas Morsi was elected by 51.7 percent. ${ }^{314}$ After his landslide victory, Aristede remained popular, but Morsi later became deeply unpopular. ${ }^{315}$

African Union, which prohibits unconstitutional change of government.").

309 David D. Kirkpatrick, Army Ousts Egyptian President; Morsi Is Taken into Military Custody, N.Y. TIMES (July 4, 2013), http://www.nytimes.com/2013/07/04/ world/middleeast/egypt.html [http://perma.cc/8UK9-KQY9]; see also Timothy Guzman, Haiti's Struggle for Freedom: U.S. Imperialism, Minustah and the Overthrow of JeanBertrand Aristede, GLOBAL RES. (Jan. 11, 2015), http:/www.globalresearch.ca/haitisstruggle-for-freedom-us-imperialism-minustah-and-the-overthrow-of-jean-bertrand-aristi de/5316972 [http://perma.cc/9XXQ-GCG5] (describing the September 29, 1991 coup d'état in Haiti).

310 Michael R. Hall, Historical Dictionary of Haiti 8 (2012).

311 Sherif Tarek, Morsi Declared Egypt's First Civilian President, AHRAM OnLINE (June 24, 2012), http://english.ahram.org.eg/NewsContent/36/0/46061/Presidentialelections-/0/Morsi-declared-Egypts-first-civilian-president,--bu.aspx [http://perma.cc/ KYV4-64FU].

312 See Paul Quinn, Officials Report on Haiti: Talbott Tells Congress Elections, Judicial System Due by Feb. of '96, Boston Globe (Feb. 25, 1995), https://www.highbeam.com/doc/1P2-8317395.html [https://perma.cc/6H3Z-3UFG]. One colleague notes that the difference between the Haiti overthrow and the Morsi overthrow may have been that the United States' interests differed in the two cases. Comments of Professor Sahar Aziz (2015) (on file with author).

313 HALL, supra note 310.

314 David D. Kirkpatrick, Named Egypt's Winner, Islamist Makes History, N.Y. TIMES (June 25, 2012), http://www.nytimes.com/2012/06/25/world/middleeast/mohamed-morsiof-muslim-brotherhood-declared-as-egypts-president.html [http://perma.cc/KLH79VV2].

315 See Götz-Dietrich Opitz, Haitian RefugeEs Forced to Return: Transnationalism and State Politics, 1991-1994, at 296 (2004) (noting that 
If coups against democratically elected leaders can ever be justified, the overthrow of President Manuel Zelaya of Honduras was far more defensible than that of President Morsi. President Zelaya's overthrow, however, was widely condemned by the international community and by international organizations. ${ }^{316}$ There, the Honduran President sought to hold a referendum to gain the people's approval to establish a constituent assembly to rewrite the Honduran constitution to extend his term of office. A Honduran court issued an injunction against President Zelaya, ordering him to stop the referendum's holding, reasoning that such a referendum violated the Honduran constitution. ${ }^{317}$ President Zelaya ignored the order and a later Honduran Supreme Court order to the same effect. ${ }^{318}$ The Honduran Supreme Court then ordered Zelaya's arrest. ${ }^{319}$ The military stormed the President's palace at dawn, took him to the airport and put him on a plane to Costa Rica. ${ }^{320}$ Apparently, the Honduran Supreme Court and Congress feared that Zelaya was trying to establish a Hugo-Chavez-type regime in Honduras. ${ }^{321}$

The Honduran Constitution (like the Egyptian Constitution then in effect) lacked a provision for impeaching the president. ${ }^{322}$ The Honduran coup had the bipartisan support of the Honduran Congress, including Zelaya's own Liberal Party, the presidential candidates of Zelaya's party, and the opposition national party. ${ }^{323}$

Aristede's popularity ballooned after the coup).

316 Elisabeth Malkin, Honduran President Is Ousted in Coup, N.Y. Times (June 28, 2009), http://www.nytimes.com/2009/06/29/world/americas/29honduras.html [http:// perma.cc/9NQW-EED8].

317 Frank Walsh, The Honduran Constitution Is Not a Suicide Pact: The Legality of Honduran President Manuel Zelaya's Removal, 38 GA. J. INT'L \& COMP. L. 339, 341-43 (2010).

318 Id. at $341-48$.

319 Id. at $345-46$.

320 Id. at 342. One commentator noted that Zelaya posed a threat to then-existing elite power structure. ThOMAs M. LeOnARD, THE History of Honduras 176 (2011) ("President Zelaya stood a threat to Honduras' existing order of elite domination of the government, economy, and society.”).

321 Greg Benchwick, Honduras and the Bay Islands 34 (2010).

322 See Mariano Castillo, Years After Crisis, Honduras Considers Impeachment, CNN (Jan. 23, 2013), http:/www.cnn.com/2013/01/23/world/americas/honduras-impeachment/ [http://perma.cc/SC3V-XTBU].

323 Thomas Legler, Learning the Hard Way: Defending Democracy in Honduras, 65 INT'L J. 601, 606-07 (2010). For an opposing view, see Ronald W. Cox, The U.S. Role in 
Furthermore, the coup had the support "of the supreme court, the office of the attorney general, the supreme electoral tribunal, ... the national human rights ombudsman[,] . . . the senior hierarchy of the Catholic Church ... as well as Protestant evangelical groups." 324 Had there been a provision for impeachment in the Honduran Constitution, it is likely that Zelaya would have been impeached.

Nevertheless, the ousting of President Zelaya was condemned by the U.N. General Assembly, by the Organization of American States, by the Inter-American Commission of Human Rights, by Latin American and other countries, and by the United States. ${ }^{325}$ The World Bank indicated it was suspending a $\$ 400$ million loan to Honduras. ${ }^{326}$ The European Union, the Inter-American Development Bank, the Central American Integration System, and the Central American Bank of Economic Integration also sanctioned Honduras. ${ }^{327}$

Despite Zelaya's unconstitutional efforts to hold the referendum and extend his power in office, the international community viewed his ouster as an illegal coup d'état. Morsi's attempts to rule by decree until the proposed Egyptian constitution was approved appear certainly no worse than what Zelaya was trying to accomplish. ${ }^{328}$ Given the extreme decision of a Mubarak-appointed

the Honduran Coup of 2009, VIEW FROM LEFT FIELD (Sept. 9, 2014), http://www.viewfromleftfield.com/the-us-role-in-the-honduran-coup-of-2009/ [http:// perma.cc/8T89-A9EQ] (noting that U.S. business groups supported the coup and that President Obama never classified the coup as a "coup" under U.S. statutes, which otherwise would have prohibited the United States from giving aid to Honduras).

324 Legler, supra note 323.

325 Douglass Cassel, Honduras: Coup d'Etat in Constitutional Clothing?-Revision, 13 AM. SOC'Y INT'L L. INSIGHTS 1, 2 (2009) (“[President Zelaya's] removal and replacement were swiftly denounced as a coup d'état by governments throughout the region, including by U.S. President Obama, and by the United Nations General Assembly, the Inter-American Commission on Human Rights, and the General Assembly of the Organization of American States (OAS). Invoking the InterAmerican Democratic Charter, the OAS General Assembly termed the coup an unconstitutional alteration of the democratic order, thus triggering the suspension of Honduras from participation in the OAS." (internal citation omitted)); see also Deadline for Honduras over Leader, BBC (July 1, 2009), http://news.bbc.co.uk/2/hi/americas/8127867.stm [http://perma.cc/ 97CAFHYG] (noting the suspension of joint military operations between the United States and Honduras).

326 Deadline for Honduras over Leader, supra note 325.

327 See Legler, supra note 323, at 601-04.

328 See Howard J. Wiarda, Dispatches From the Frontlines: Studies in ForeigN Policy, Comparative Politics, And International AfFairs 64 (2014). 
court to dissolve the Islamic-dominated lower house of parliament, ${ }^{329}$ Morsi's decision to refuse to follow judicial orders was understandable if neither legal nor wise. Given the composition of the Egyptian parliament, it is far less likely that Morsi would have been impeached had there been a constitutional impeachment provision available (and had the lower house of parliament not been dissolved). Unlike Zelaya's party, the Muslim Brotherhood certainly did not approve the coup. ${ }^{330}$ In addition, the constitution was not suspended in Honduras, but it was suspended in Egypt. ${ }^{331}$ "In Egypt, it's crystal clear that the military holds power. In the case of Honduras, the military never really had power, but rather was acting on behalf of the Supreme Court, Congress, and leaders within Mr. Zelaya's own Liberal Party." 332 Lastly, the Honduran coup aftermath pales in comparison with the Egyptian military coup leaders' violent repression of the Muslim Brotherhood, banning the organization and imprisoning all its leadership, and the harsh penalties it has visited on those Brotherhood members who have had blatantly unfair, summary mass trials. ${ }^{333}$

329 On the other hand, the Egyptian Supreme Constitutional Court had also dissolved the Parliament in 1987 and 1990. Egypt Court Orders Dissolving of Parliament, AL JAZEERA (June 14, 2012), http://www.aljazeera.com/news/middleeast/2012/06/ 2012614124538532758.html [http://perma.cc/G5V6-B9MD]; see also Sahar F. Aziz, Bringing Down an Uprising: Egypt's Stillborn Revolution, 30 CONN. J. INT'L L. 1 (2014).

330 Benjamin Wedeman et al., Egypt's Forces Move Against Muslim Brotherhood; Attacks Against Police Reported, CNN (July 4, 2013), http:/www.cnn.com/ 2013/07/04/world/meast/egypt-coup/ [http://perma.cc/LFR2-GEY7] ("On its website, the Muslim Brotherhood declared, 'our unequivocal rejection of the military coup against the elected president and the will of the nation and refuse to participate in any action with the authority that stole the power and dealt violently with peaceful demonstrators."').

331 Egypt Military: President Morsi Ousted, Constitution Suspended, CBS News (July 3, 2013), http://www.cbsnews.com/news/egypt-military-president-morsi-oustedconstitution-suspended/ [http://perma.cc/8KJK-4MZB].

332 Marco Caceres, Egypt: Another Good Coup, Huffington Post (July 4, 2013), http://www.huffingtonpost.com/marco-caceres/egypt-the-good-coup_b_3542784 [http:// perma.cc/3VU9-FX4H]. General el-Sisi, the coup leader, was ultimately elected president, but serves essentially as a military leader head of state. See Egypt's Sisi Signs Law Defining "Terrorist Entities," Ahram OnLINE (Feb. 24, 2015), http://english.ahram.org.eg/NewsContent/1/64/123810/Egypt/Politics-/Egypts-Sisi-signslaw-defining-terrorist-entities.aspx [http://perma.cc/A6VG-A4LW] (reporting that President el-Sisi personally issued a new law "broadly defining 'terrorist entities," or individuals who, among other things, "through any means inside or outside the country seek to call for the disabling of laws or prevent state institutions or public authorities from functioning" (internal citation omitted)).

333 See Egypt Unfair Trial, Death Sentences Make Mockery of Justice, AMNESTY 
The international community, however, generally failed to condemn the Egyptian military coup itself. ${ }^{334}$ The evidence of the military's aiding and abetting the protests against Morsi did not come out until months after the coup, and the delay may have dampened any outcry. ${ }^{335}$ Ironically, arresting rather than letting Morsi leave the country may also have contributed to the softer protest against the coup. (Both Aristede and Zelaya addressed the U.N. General Assembly following their coups, successfully urging the Assembly to condemn each of their military overthrows.) One hopes that the lack of protest did not stem from bias in the West against fundamentalist ideology or from distorted generalizations of Muslims, based on terrorist activity by a small fragment of the Muslim population. ${ }^{336}$ Muslim fundamentalists, whom the Muslim Brotherhood represents, certainly do not enjoy unanimous approval in the Muslim world. But assuming we accept that customary international law against the military overthrow of democratically elected governments is emerging, it is hard to deny that the Egyptian military violated that norm.

INT'L (Apr. 28, 2014), https://www.amnesty.org/en/latest/news/2014/04/egypt-unfairtrial-death-sentences-make-mockery-justice/ [https://perma.cc/4HCM-9Q3D].

334 Morsi's Punishment Is a Crime, AL JAZEERA (Apr. 21, 2015), http://www.aljazeera.com/indepth/opinion/2015/04/morsi-punishment-crime-sisi-egypt150421113902012.html [http://perma.cc/WLC3-D8JQ]. In addition, Egypt was recently elected by African countries to one of the non-permanent seats in the U.N. Security Council, perhaps owing in part to most African governments likewise perpetrating systematic human rights violations. See Somini Sengupta, Ukraine and Japan Among Latest Members of U.N. Security Council, N.Y. TIMES (Oct. 15, 2015), http:// www.nytimes.com/2015/10/16/world/ukraine-and-japan-among-latest-members-of-un-se curity-council.html [http://perma.cc/P2BN-R4J5]; see, e.g., Africa Human Rights, AMNESTY INT'L, http://www.amnestyusa.org/our-work/countries/africa [http://perma.cc/ MR7H-F2HT] (last visited Nov. 12, 2015); Freedom in the World 2015, FREEDOM HouSE (Jan. 28, 2015), https://freedomhouse.org/report/freedom-world/freedom-world2015\#.Vi5Ic9KrQps [http://perma.cc/MGW5-FH5C] ("Ratings for the Middle East and North Africa region were the worst in the world, followed by Eurasia. Syria, a dictatorship mired in civil war and ethnic division and facing uncontrolled terrorism, received the lowest Freedom in the World score of any country in over a decade.").

335 Id.

336 Egypt's Invisible Protesters, One Year After Coup, MidDLE E. Eye (July 4, 2014), http://www.middleeasteye.net/columns/egypt-s-invisible-protesters-one-year-after-coup10908636261090863626p [http://perma.cc/QLR8-PVGM]. 


\section{B. Human Rights Law and the Aftermath of the Military Coup}

Aside from the emerging illegality of overthrowing a democratic government, the military in carrying out a coup and in solidifying their power usually violates international human rights law and sometimes, if a civil war breaks out, international humanitarian law as well. ${ }^{337}$ As noted above, the Egyptian military regime has engaged in repeated, serious human rights violations since deposing President Morsi. ${ }^{338}$ In this period, the Egyptian government has continuously violated customary international law and numerous provisions of the foundational human rights treaty, the International Covenant on Civil and Political Rights, ("ICCPR"). ${ }^{339}$ Under the ICCPR, each state party is required to respect the rights of "all individuals" without "distinction of any kind, such as ... religion or other opinion." 340 The ICCPR also guarantees each citizen the right to "take part in the conduct of public affairs ... through freely chosen representatives." ${ }^{341}$ The Egyptian military coup itself arguably violates the latter article. By overthrowing Morsi and by dissolving the Parliament, the military (and an Egyptian court) directly interfered with Muslim Brotherhood members' right to "take part in the conduct of public affairs ... through freely chosen representatives." ${ }^{342}$ Banning the Muslim Brotherhood altogether on frivolous grounds unquestionably amounted to discrimination on the basis of

337 See Denmark, Norway \& Sweden v. Greece, 1969 Y.B. Eur. ConV. ON H.R. (Eur. Comm'n of H.R.) 586 (finding flagrant violations of human rights committed by the Greek military regime after conducting a coup d'état).

338 See Egypt Military Court Sentences 253 to Life in Prison in Absentia, Aswat MASRIYA (Aug. 11, 2015), http://en.aswatmasriya.com/news/view.aspx?id=19878b57f813-49b2-ad6b-8b44b4d09be1 [http://perma.cc/2CWZ-78Z2].

339 See International Covenant on Civil and Political Rights art. 1, opened for signature Dec. 16, 1966, 999 U.N.T.S. 171 (entered into force Mar. 23, 1976) [hereinafter ICCPR]. Egypt is also party to the U.N. Convention against Torture, the U.N. Convention on the Rights of the Child, to Convention on the Elimination of Discrimination against Women, and the International Covenant on Economic, Social and Cultural Rights. Ratification of Human Rights Treaties-Egypt, U. MinN. HuM. RTS. LiBR., http://www.umn.edu/humanrts/research/ratification-egypt.html [http://perma.cc/6JKFMUCV] (last visited Aug. 31, 2015).

340 ICCPR, supra note 339 , art. 2(1).

341 Id. art. 25(a).

342 See id. art. 25(a). 
"religion, political or other opinion" 343 and again directly interfered with the right of Muslim Brotherhood members to participate in government "through freely chosen representatives." 344

The ICCPR also requires each state party to guarantee the freedoms of expression, of assembly, and of association. ${ }^{345}$ By imprisoning and convicting journalists for reporting events that the government does not like exposed, the Egyptian government again has violated its obligation to respect freedom of expression. ${ }^{346}$ The government's repression of peaceful demonstrations constitutes an egregious violation of both the freedom of assembly and of association.

Under Article 6 of the ICCPR, the Egyptian authorities are expressly prohibited from arbitrarily taking the life of their own nationals or anyone else. ${ }^{347}$ Law enforcement personnel may use deadly force only when their lives or others' are in imminent danger of death or serious bodily harm. ${ }^{348}$ By aiming at the head and chest of demonstrators and killing hundreds of them, the Egyptian Security Forces engaged in "arbitrary" taking of life in violation of article 6 of the ICCPR and of the customary law obligation to minimize the use of deadly force. ${ }^{349}$

Although the death penalty is not yet banned under international

343 Cf. Metro Church of Bessarabia v. Moldova, 2001-XII Eur. Ct. H.R. 860 (state's refusal to permit breakaway Orthodox Christian Church to operate violated "freedom of religion" guarantee of the European Human Rights Convention).

344 ICCPR, supra note 339, art. 25(a).

345 Id. arts. 19-21.

346 Article 19(2) of the ICCPR guarantees freedom of expression, but article 19(3) allows governments to limit the freedom of expression on, among other grounds, "[f]or the protection of national security or of public order (ordre public), or of public health or morals." Id. art. 19(3) (emphasis added). Protection of national security or public order does not extend to imprisoning journalists for accurately reporting government shooting and killing demonstrators. See Sarah Joseph, A Rights Analysis of the Covenant on Civil and Political Rights, 5 J. InT'L Legal Stud. 57, 78-79 (1999); Amit Mukherjee, International Protection of Journalists: Problem, Practice, and Prospects, 11 ARIZ. J. INT'L \& COMP. L. 339, 356 (1994).

347 ICCPR, supra note 339, art. 6(1).

348 See Eighth Congress on the Prevention of Crime and the Treatment of Offenders, Aug. 27-Sept. 7, 1990, Basic Principles for the Use of Force and Firearms by Law Enforcement Officials, ๆ 9, U.N. Doc. A/CONF.144/28/Rev.1 ("Law enforcement officials shall not use firearms against persons except in self-defen[s]e or defen[s]e of others against the imminent threat of death or serious injury ....”).

349 See id. I 5; ICCPR, supra note 339, art. 6(1) ("[N]o one shall be arbitrarily deprived of his life."). 
law, individuals subject to the death penalty are entitled to a fair trial. $^{350}$ Holding summary mass trials in capital cases makes a mockery of this obligation. ${ }^{351}$ Egypt's campaign of terror against the Muslim Brotherhood and its arrest of thousands without reasonable cause and subsequently failing to provide them a fair trial likewise violate both the ICCPR and customary international law. ${ }^{352}$

Furthermore, Article 7 of the ICCPR prohibits torture and cruel, inhuman and degrading treatment. ${ }^{353}$ Like the right to life, this obligation is strict. ${ }^{354}$ States may not derogate from it even in cases of public emergency. ${ }^{355}$ By increasing the operation of its already busy torture chambers, ${ }^{356}$ Egypt has regularly violated Article 7, an equivalent bar under the Torture Convention, and peremptory

350 See ICCPR, supra note 339, arts. 4(2), 6(1), 6(2), 9. Article 6 is non-derogable. Id. art. 4(2).

351 See Egypt: U.N. Experts "Outraged” at Confirmation of 183 Death Sentences, United Nations Hum. RTs. OfF. High Commissioner (June 30, 2014), http://www.ohchr.org/EN/NewsEvents/Pages/DisplayNews.aspx?NewsID=14801\&Lang $\mathrm{ID}=\mathrm{E}$ [http://perma.cc/3KBL-QC77] ("We are shocked by the repeated and deliberate use of mass death sentences.... We are deeply concerned that the courts have become instrumental in the arbitrary and politically motivated prosecutions by the State, which may also be discriminatory against people on the basis of religion or belief.").

352 See ICCPR, supra note 339, arts. 9, 19; G.A. Res. 217 (III) A, Universal Declaration of Human Rights arts. 3, 9, 10 (Dec. 10, 1948) (guaranteeing fair trial in criminal proceedings) [hereinafter UDHR]; Egypt: ICJ Condemns Further Mass Death Sentences, supra note 272 ("Trials with heavy-handed sentences should not be used to repress and intimidate political opponents. The climate in Egypt is currently one where individuals are being prosecuted and sentenced for exercising their right of freedom of association and assembly."); FrEEDOM HousE, supra note 167, at 6 (noting freedom deterioration in Egypt).

353 See ICCPR, supra note 339 , art. 7.

354 See id. art. 4(2).

355 See id.

356 See Walaa Ramadan, Torture in Egyptian Prisons Was Once a Cause for Revolt, Now It's Met by Silence, MEMO MidDle E. Monitor (Aug. 6, 2014), https:// www.middleeastmonitor.com/articles/africa/13272-torture-in-egyptianegyptian-prisonswas-once-a-cause-for-revolt-now-its-met-by-silence [https://perma.cc/749D-W9RR] (citing Wiki Thawra reporting that "at least 80 detainees have died" in Egyptian prisons from July 3, 2013 to May 2014 and large numbers tortured); Jesse Rosenfeld, Egypt's Black Site Torture Camps, DAILY BEAST (June 19, 2014), http://www.thedailybeast.com/ articles/2014/06/19/egypt-s-black-site-torture-camps.html [http://perma.cc/ATM8QKRQ] (describing the "black site prisons" used by the Egyptian army to torture young protestors). 
norms of customary international law. ${ }^{357}$

\section{International Law, Colonization, Annexation, Discrimination, and the West}

Aside from the illegality of the coup and widespread international human rights violations perpetrated by the Egyptian military, the West's 200 year encounter with Egypt would now violate fundamental principles of international law. Having experienced the horror of two world wars, the framers of the U.N. Charter outlawed the use or threatened use of armed force except in self-defense or under U.N. Security Council authorization: "All Members shall refrain in their international relations from the threat or use of force against the territorial integrity or political independence of any state, or in any other manner inconsistent with the Purposes of the United Nations." 358

The most important world treaty with 193 states parties, the U.N. Charter thus prohibits aggressive warfare. ${ }^{359}$ While not abolishing colonies as such, the Charter makes it very hard for

357 See Comm. Against Torture, Conclusions and Recommendations of the Committee Against Torture: Egypt on its 29th Sess., Dec. 23, 2002, U.N. Doc. $\mathrm{CAT} / \mathrm{C} / \mathrm{CR} / 29 / 4$ ("Express[ing] particular concern at the widespread evidence of torture and ill-treatment in administrative premises under the control of the State Security Investigation Department.").

357 The civil and political rights set forth in the Universal Declaration of Human Rights (UDHR) are generally considered to have crystallized into customary international law. See Filartiga v. Pena-Irala, 630 F.2d 876, 881-82 (2d Cir. 1980); UDHR, supra note 352 , art. 3 ("Everyone has the right to life, liberty and security of person."); id. art. 5 ("No one shall be subjected to torture or to cruel, inhuman or degrading treatment or punishment."); id. art. 9 ("No one shall be subjected to arbitrary arrest, detention or exile."); id. art. 11 ("[T] he right to be presumed innocent until proved guilty according to law in a public trial at which he [the accused] has had all the guarantees necessary for his defence."); id. art. 19 ("Everyone has the right to freedom of opinion and expression; this right includes freedom to hold opinions without interference and to seek, receive and impart information and ideas through any media and regardless of frontiers."); id. art. 20 ("(1) Everyone has the right to freedom of peaceful assembly and association. (2) No one may be compelled to belong to an association.").

358 U.N. Charter art. 2, $₫ 4$. Article 51 of the Charter permits the use of proportional force in the case of self-defense. See id. art. 51. Chapter VII of the U.N. Charter authorizes the U.N. Security Council to call on members to use armed force in cases where there is a "threat to the peace." See id. arts. 39, 42 (authorizing U.N. Security Council to act).

359 The widely accepted U.N. General Assembly Resolution on Aggression fleshes out the meaning of article 2(4) of the Charter and includes, among others, invasion or attack, bombardment, blockade, and use of irregular or proxy forces. See G.A. Res. 3314 (XXIX), Definition of Aggression art. 3 (Dec. 14, 1974). 
powerful states to legally establish new colonies. ${ }^{360}$ Although the Charter has not stopped warfare, with a few significant exceptions, ${ }^{361}$ it has stopped more powerful states from annexing territory of less powerful states. When combined with the ICCPR and International Covenant on Economic, Social and Cultural Rights ("ESCR"), both of which expressly recognize the right of self-determination, the U.N. Charter forbids acquisition of new colonies. ${ }^{362}$ The Charter also established a trustee system to encourage, more effectively than the League of Nations mandate system, colony-holding states to relinquish their long-held colonies. $^{363}$

360 The legal regime before the U.N. Charter endorsed colonization. For example, especially in the nineteenth century, "[g]iven the military weakness of the non-European states, and the absence of any legal limitations on a state's ability to commence a war, it was inevitable that European empires would expand by the conquest of large parts of Asia and Africa." Antony Anghie, Imperialism, Sovereignty AND the MAKing of International LAw 83 (2004); see also Antony Anghie, Finding the Peripheries: Sovereignty and Colonialism in Nineteenth-Century International Law, 40 HARV. INT'L L.J. 1, 50 n.175 (1999) ("Conquest seems to have been officially outlawed in contemporary international law as a means of acquiring title to territory ....”).

361 China's conquering and annexing Tibet, and Russia's annexing Crimea last year are two of the starkest examples of illegal annexations. See, e.g., Robert D. Sloane, The Changing Face of Recognition in International Law: A Case Study of Tibet, 16 EMORY InT'L L. Rev. 107, 131 (2002); Gaetano Pentassuglia, Putin Should Know That Crimea Is Not Kosovo When It Comes to Self-Determination, Conversation (Mar. 31, 2014), http:// theconversation.com/putin-should-know-that-crimea-is-not-kosovo-when-it-comes-to-sel f-determination-24916 [http://perma.cc/QN2Z-N39N]. Russia has argued, among other things, that the doctrine of self-determination justified the annexation of Crimea, an argument rarely accepted in the case of so-called external self-determination. See id. (reporting Putin arguing that self-determination justified the annexation). Cf. Shahrough Akhavi, Muslim Perspectives on the Invasion of Iraq, in ENEMY CombatAnTs, TERRORISM, AND ARMED CONFLICT LAW: A GUIDE TO THE IsSUES 37, 41 (David K. Linnan ed., 2008) (discussing the Islamic world's negative perception of the invasion of Iraq as an unjustified external intervention).

362 See ICCPR, supra note 339 ("1. All peoples have the right of self-determination. By virtue of that right they freely determine their political status and freely pursue their economic, social and cultural development.... 3. The States Parties to the present Covenant, including those having responsibility for the administration of Non-SelfGoverning and Trust Territories, shall promote the realization of the right of selfdetermination, and shall respect that right, in conformity with the provisions of the Charter of the United Nations." (emphasis added)); G.A. Res. 2200A (XXI), International Covenant on Economic, Social and Cultural Rights art. 1 (Dec. 16, 1966) [hereinafter ESCR].

363 George Thullen, Problems of the Trusteeship System: A Study of Political Behaviour in the United Nations 88 (1964). The tidal wave of the independence movement in the 1960's played a greater role. Id. at 120. 
Had it been in force at the time, the U.N. Charter, for example would have prohibited Napoleon from conquering Egypt in 1798, would probably have prohibited Muhammad Ali from taking over Egypt in 1801 and 1807, and would probably have prohibited England from colonizing Egypt in 1882. The Charter did prohibit the use of force to retake the Suez Canal in 1956. ${ }^{364}$ The Egyptian encounter with the West produced an unhealthy alchemy, contributing to the growth of authoritarian Egyptian regimes, to the conflict between Muslim secularists and Muslim fundamentalists, and to the creation of rebels of different ideological and religious bents, striving to throw off the colonial yoke and the repressive regimes which developed in the colonial governments' place.

International law does not fully provide an answer to Egypt's troubles or to the West's and Russia's struggle with Islamic terrorism. International law, however, can help policy makers better understand the forces driving Islamic terrorism and guide the West, in general, and the United States in particular towards more effective and less violent counter-terrorism policies and practices. Under international law, States are responsible only for their acts that were illegal at the time the state committed them. Absent express agreement to the contrary, international law does not apply retrospectively. The International Law Commission's draft articles on state responsibility so provide, "An act of a State does not constitute a breach of an international obligation unless the State is bound by the obligation in question at the time the act occurs." 365 Called the doctrine on intertemporal law, this principle applies even to acts that subsequently have become proscribed under a peremptory norm of international law. ${ }^{366}$ The judge in the Island of Palmas arbitration explained, "A juridical fact must be appreciated in light of the law contemporary with it and not the law in force at

364 See G.A. Res. 3314, supra note 359.

365 Draft Articles on Responsibility of States for Internationally Wrongful Acts arts. 13, 57, Rep. on its 53d Sess., Apr. 1-June 1, July 2-Aug. 10, 2001, U.N. Doc.A/56/10 (2001) (emphasis added); see also JAMES CrAWford, THE InTERnATIONAL LAW Commission's ARTicles on StATE Responsibility 131 (2002) (expounding on the principle that States are not responsible for the "retrospective application of international law").

366 See CRAWFORD, supra note 365; T.O. Elias, The Doctrine of Intertemporal Law, 74 AM. J. INT'L L. 285 (1980) (describing the concept of intertemporal law and its historical underpinnings). 
the time when a dispute in regard to it arises." ${ }^{367}$ It has been held, for example, that British interception of foreign slave traders' ships in the nineteenth century violated international law when the British had done so before the slave trade "had been "prohibited." 368 African-Americans suffered under the "separate but equal doctrine" before the landmark case of Brown v. Board of Education in 1954 declared the doctrine unconstitutional. ${ }^{369}$ Likewise, the pain, humiliation, and resentment engendered by conquest, colonization, and accompanying racial discrimination ${ }^{370}$ had been just as sharply felt by the people experiencing these practices before the international community formally outlawed them. ${ }^{371}$

367 Island of Palmas (U.S. v. Netherlands), 2 R.I.A.A. 829, 845 (Perm. Ct. Arb. 1928) (emphasis added); see also MCDONNELL, supra note 7, at 280 (describing how the doctrine of intertemporal law solves problems of past annexation).

368 CRAWFORD, supra note 365 (citations omitted). Historical wrongs may be judicially cognizable only under narrow circumstances. See Dinah Shelton, Intergenerational Equity, in SOLIDARITY: A StRUCTURAL PRINCIPLE OF INTERNATIONAL LAW 123, 136 (Rudiger Wolfrum \& Chie Kojima eds., 2010) (arguing for reparations for historical violations); Western Sahara, Advisory Opinion, 1975 I.C.J. Rep. 12, 39 (Oct. 16) (discussing the decolonization of Western Sahara and finding no ties of territorial sovereignty); Moiwana Village v. Suriname, Preliminary Objections, Merits, Reparations, and Costs, Judgement, Inter-Am. Ct. H.R. (ser. C) No. 142, ๆ 43 (June 15, 2005) (concluding that the massacre of a village occurring before Suriname had ratified the American Convention on Human Rights was nevertheless actionable after ratification on a continuing wrong theory).

369347 U.S. 483, 493 (1954).

370 See Australian Human Rights Comm'n, Bringing Them Home: National INQUIRY INTO THE SEPARATION OF ABORIGINAL AND TORRES STRAIT ISLANDER CHILDREN FROM THEIR FAMILIES ch. 14 (1997) (finding that under international law, from approximately 1946 the policies of forcible removal amount to genocide, and from 1950 the continuation of distinct laws for Indigenous children was racially discriminatory).

371 For historical reasons, the Islamic world did not embrace the scientific method, capitalism, and the industrial revolution. See Hillel Ofek, Why the Arabic World Turned Away from Science, The New AtLantis 3, 13-15 (2011). The West did embrace all these things and became both economically and militarily more powerful. Id. at 18 . In the fifteenth and sixteenth centuries, the Ottoman Empire was the world's superpower. See also Stanford J. Shaw \& Gökhan Çetinsaya, Ottoman Empire, Oxford Islamic STUD. ONLINE, http://www.oxfordislamicstudies.com/article/opr/t236/e0611 [http://perma.cc/ CX92-GCT3] (last visited Nov. 12, 2015) (describing the Ottoman Empire's rise to world power). It thus must have been particularly humiliating to have been outdone by the Europeans, which had formerly been second rate powers. Id. That is how American auto manufacturers must have felt when the Japanese began to make better cars than Detroit and dominate the American market. It must have been like many Americans might feel if Mexico were ever to invade and conquer the United States, take back Texas, New Mexico, Arizona, and California and subject the rest of the United States to Mexican rule. 
Although under no legal obligation to make reparation in such circumstances, states may do so. "[A] state may agree to compensate for damage caused as a result of conduct which was not a breach of any international obligation at the time it was committed." ${ }^{372}$ Although international law prohibiting racial and nationality discrimination was not clearly recognized until after World War II, ${ }^{373}$ the United States compensated Japanese Americans and Japanese nationals who were detained and held in internment camps during that conflict. ${ }^{374}$ Again largely on moral grounds, the United States has compensated foreign nationals in other situations in which international law did not render the United States legally responsible for the wrong. ${ }^{375}$ Other states have done

372 CRAWford, supra 365, at 132-33 (quoting Commentaries). The rule of intertemporal law likewise applies to states and religious organizations that discriminated against Jews for over two millennia. One would imagine, however, that religious organizations, if not states, would make reparation as a moral duty. The reparations movement has had some success in obtaining restitution and other settlement for Holocaust victims, but even by 1939, war crimes and genocide were implicitly recognized as violations of international law, so there really is no retroactivity problem.

373 The U.N. Charter, not open for signature until 1945, provides that "United Nations shall promote: . . . universal respect for, and observance of, human rights and fundamental freedoms for all without distinction as to race, sex, language, or religion" and that "[a]11 members shall pledge themselves to take joint and separate action" to achieve the same. See U.N. Charter arts. 55, 56 (emphasis added). The seminal California Supreme Court case of Sei Fujii v. State, implicitly concluded that the "promote" and "pledge" language was not sufficiently definite to create legally binding "rules of law." $38 \mathrm{Cal}$. 2d 719, 722 (1952) (noting that the language of the U.N. charter in article 55 was too vague to be binding). The International Court of Justice, however, did conclude that this language was strong enough to render illegal South Africa's then system of apartheid. See Legal Consequences for States of the Continued Presence of South Africa in Namibia (South West Africa), Advisory Opinion, 1971 I.C.J. 78, I 131 (June 21) (concluding the government policy of discrimination in South Africa violated the language of the U.N. Charter). The anti-discrimination provisions of The Universal Declaration of Human Rights, passed without dissent, by the U.N. General Assembly in 1948, did not, however, crystallize into custom until sometime later.

374 See Civil Liberties Act of 1988, 50 U.S.C. $\S \S 1989$ b-1 to -9 (1988) (authorizing survivors of Japanese internment be compensated in the amount of $\$ 20,000$ each); Motoyoshi v. United States, 33 Fed. Cl. 45, 48 (1995) (discussing the $\$ 20,000$ compensation under the Civil Liberties Act).

375 Most notably, United States has compensated civilians who have suffered from American military operations in wartime in Afghanistan, Iraq, and other theatres even absent any showing that the United States was legally responsible. See AMSTERDAM International LAW Clinic, MONETARy PAyments FOR Civilian HaRm in INTERNATIONAL AND NATIONAL PRACTICE 13-16 (2013), http://www.uva.nl/ binaries/content/assets/subsites/amsterdam-international-law-clinic/monetary-payementsreport.pdf [http://perma.cc/ZE3Q-39DN]. The U.S. practice dates back to World War I. 
so as well. ${ }^{376}$ For example, New Zealand set up a program "to address the wrongs committed by the British government during its colonial rule against the Maori during the late 1800s." 377 Thus in dealing with such wrongs, for most claimants, "reparation is a moral issue involving a formal acknowledgement of historical wrong, recognition of continuing injury, and commitment to redress." 378

Since the end of World War II, the international community has outlawed state conquest, colonization and systematic racial discrimination. ${ }^{379}$ Should the international community now ignore

See Sarah Holewinski, Making Amends: A New Expectation for Civilian Losses in Armed Conflict, in Civilians and Modern War: Armed Conflict and the IdeOlogy of VIOLENCE 317, 322-23 (2012) (dating the concept of making amends back to WWI). Winning (or at least not losing) hearts and minds by "making amends" may also play into the U.S. decision to compensate. See id. at 320-21 (detailing the reasons the U.S. makes amends); Sahr Muhammedally, Civilians War Victims Receive Recognition in U.S. Law, CTR. FOR CIVILIANS CONFlict (Apr. 3, 2014), http://civiliansinconflict.org/ resources/news/civilian-war-victims-receive-recognition-in-us-law [http://perma.cc/ CB74-J6MY] (explaining the importance of making amends); 2 HERSH LAUTERPACHT, International Law, Being the Collected Papers: The LAW of PeAce 230, 232 (1975) (quoting with approval case of Hardman (Gr. Brit. v. U.S.), R.I.A.A. 25, 26 (Perm. Ct. Arb. 1923) ("Although there is no legal obligation to act in that way, there may be a moral duty which cannot be covered by law, because it is grounded on an inmost sense of human assistance [and the ability of the nation to pay].")).

376 For example, Georgia paid \$250,000,000 to South Ossetians who suffered property damage in the 2009 conflict with Russia. See Holewinski, supra note 375, at 325. In 2009, the commander of the African Union Mission in Somalia "offered \$7,600 to local traders for the camels that his troops accidentally killed in Mogadishu." Id.

377 James Thomas \& David Brunsma, Bringing down the House: Reparations, Universal Morality, Human Rights and Social Justice, in GLOBALIZATION AND AMERICA: RACE, Human Rights, AND INEQuAlity 65, 70 (Angela Hattery et al. eds., 2008).

378 Shelton, supra note 368 (emphasis added). Former colonial states providing "development aid" to their former colonies can be viewed as providing reparation for historical wrongs. See Jeremy Sarkin, Colonial Genocide and Reparations Claims IN THE 21ST CENTURY 193-94 (2009).

379 See ICCPR, supra note 339. The Universal Declaration of Human Rights, ("UDHR") which was passed by the U.N. General Assembly in 1948 without a dissenting vote, expressly prohibits discrimination on the basis of race, religion, nationality, and former colonial status of territory. "Everyone is entitled to all the rights and freedoms set forth in this Declaration, without distinction of any kind, such as race, colo[]r, sex, language, religion, political or other opinion, national or social origin, property, birth or other status. Furthermore, no distinction shall be made on the basis of the political, jurisdictional, or international status of the country or territory to which a person belongs, whether it be independent, trust, non-self-governing, or under any other limitation of sovereignty." UDHR, supra note 352, art. 2 (emphasis added) (prohibiting discrimination on the basis of race). The prohibitions of this most famous General Assembly resolution were subsequently codified in numerous multi-lateral treaties, including among others, the 
the wrongs that individuals and peoples were subjected to before these three, related practices were legally banned? This article contends both as a matter of enlightened self-interest and as a matter of elemental morality and justice that policy makers must take into account these past wrongs endured by all peoples in the Middle East

International Covenant on Civil and Political Rights, Dec. 16, 1966, 999 U.N.T.S 171; International Convention on the Elimination of All Forms of Racial Discrimination ("CERD"), Dec. 16, 1966, 660 U.N.T.S. 195; Convention on the Suppression and Punishment of the Crime of Apartheid, Nov. 30, 1973, 1015 U.N.T.S. 243; and Convention on the Rights of the Child art. 2, Nov. 20, 1989, 1577 U.N.T.S. 3. Adopted in 1965 by unanimous vote of the General Assembly, the International Convention to Eliminate Race Discrimination has been, as of this writing, signed by eighty-eight nations with 177 states parties. Status of Treaties, United NATIONS TREATY COLLECTION, https://treaties.un.org/ Pages/ViewDetails.aspx?src=TREATY\&mtdsg_no=IV-2\&chapter=4\&lang=en $\quad[\mathrm{http}: / /$ perma.cc/M8M4-B2FV] (last visited Oct. 25, 2015) (listing parties who have signed CERD). The Convention prohibits "any distinction, exclusion, restriction or preference based on race, colour, descent, or national or ethnic origin which has the purpose or effect of nullifying or impairing the recognition, enjoyment or exercise, on an equal footing, of human rights and fundamental freedoms in the political, economic, social, cultural or any other field of public life." International Convention on the Elimination of All Forms of Racial Discrimination, art. 1(1) Dec. 16, 1966, 660 U.N.T.S. 195 [hereinafter CERD] (emphasis added) (defining racial discrimination). Furthermore, the United States Restatement (Third) of Foreign Relations concludes that the prohibition on "systematic racial discrimination" rises to the level of a peremptory norm of international law. RESTATEMENT (THIRD) OF FoREIGN RELATIONS § 702(f) (AM. LAW INST. 1990) (setting forth that a state violates international law if it promotes or "condones" racial discrimination). The Restatement notes that systematic discrimination on the basis of religion enjoys similar status. Id. $\mathrm{cmt}$. j; see also General Recommendation XIII on the Training of Law Enforcement Officials in the Protection of Human Rights, Comm. on the Elimination of Racial Discrimination, 42d Sess., U.N. Doc. A/42/18 (Mar. 16, 1993). See generally Maria V. Morris, Racial Profiling and International Human Rights Law: Illegal Discrimination in the United States, 15 EMORY INT'L L. REV. 207 (2001) (discussing the deleterious effects of racial profiling on minorities). International Tribunals have ruled that racial discrimination violates international law and the proscription of such discrimination has become a peremptory norm of international law. See, e.g., Juridical Condition and Undocumented Migrants, Advisory Opinion OC-18/03, Inter-Am. Ct. H.R. (ser. A) No. 18 (Sept. 17, 2003) ("The international community is unanimous in considering that the prohibition of racial discrimination and of practices directly associated with it is an obligation erga omnes."). The European Court of Human Rights has ruled that the state has an obligation to investigate whether racism motivated state officials in using excessive force in killing members of a minority group, suspected of a criminal offense. See Nachova v. Bulg., 2005-VII Eur. Ct. H.R. 40, http://www.echr.coe.int/ Documents/Reports_Recueil_2005-VII.pdf [https://perma.cc/Y3HM-SLNZ] (upholding the lower court, "Where there is suspicion that racial attitudes induced a violent act it is particularly important that the official investigation is pursued with vigour and impartiality, having regard to the need to reassert continuously society's condemnation of racism and ethnic hatred and to maintain the confidence of minorities in the ability of the authorities to protect them from the threat of racist violence"). 
and the Islamic World, particularly at the hands of the West and Russia. $^{380}$

\section{United States Flawed Response to the Coup d'État}

By essentially ratifying, if not initially supporting the Egyptian military's coup d'état, the United States falls into the same narrative that probably led to the September 11 attacks. ${ }^{381}$ The West's exploiting Arab and Muslim countries by colonizing them demonstrates at the very least the callous indifference of the West to the plight of Arab and Muslim peoples. The United States has shown indifference if not outright hostility to emerging democratic institutions in the Islamic world. By supporting authoritarian rulers from the Shah of Iran, to Saddam Hussein, to Hosni Mubarak, to Saudi Arabia's House of Saud, to the draconian heads of the tiny oil emirates, the United States has implicitly helped these regimes to smother the possible emergence of democratic movements in their countries. ${ }^{382}$ As observed above, the United States brought about the coup that deposed the democratically-elected Prime Minister of Iran in 1953. ${ }^{383}$ The United States supported the Algerian military's coup on the eve of elections that the Muslim Brotherhood candidates almost certainly would have won in 1991.384

380 On Russian colonization of Muslim countries, see COOPER \& YUE, supra note 6.

381 Secretary of State John Kerry visited President el-Sisi the day after an Egyptian court ratified the death sentences of 183 Muslim Brotherhood members, including Muhammad Badie, the spiritual guide of the Brotherhood. See Ricardo Gonzalez, Kerry Supports Egypt's Sisi, President and Leader of Coup d'État, El PAIS (June 22, 2014), http://internacional.elpais.com/internacional/2014/06/22/actualidad/1403465904_897931 .html [http://perma.cc/WD8E-MNYK].

382 Secretary of State James Schlesinger testified before Congress as follows: "Do we seriously want to change the institutions of Saudi Arabia? The brief answer is no; over the years we have sought to preserve those institutions, sometimes in preference to more democratic forces coursing throughout the region." See Hashemi, supra note 167, at 42 (citation omitted).

383 Dan Merica \& Jason Hanna, In Declassified Document CIA Acknowledges Role in '53 Iran Coup, CNN (Aug. 19, 2013), http://www.cnn.com/2013/08/19/politics/cia-iran1953-coup/index.html [http://perma.cc/43M7-WLKH].

384 Beverly Milton-Edwards, The Democratic Freedom Deficit in the Middle East, in IraQ, Democracy AND THE Future OF THE MuSLIM World 130, 141(Ali Paya \& John L. Esposito eds., 2011) (“This ambiguity of 'double-standards' in western democracy promotion is keenly felt elsewhere across the Middle East; countless press commentaries in the Arabic press opine at US and Western support more generally for some democratic regimes and movements in the region and their opposition and desire to damage others. Democracy in the Middle East was supposed to be the launch-pad for a new orientation of 
Furthermore, the United States did little to advance respect for democratic rule in Egypt while its client Mubarak for nearly three decades ruthlessly dealt with Brotherhood members and Brotherhood candidates for office. ${ }^{385}$ Geopolitical interests in oil, in "stability," in preventing communism were made far higher priorities than fostering the fundamental human rights for the people living in this region. ${ }^{386}$

United States' interests in having a strong relationship with Egypt are no less critical today. While the Suez Canal may have been colonial Britain's "highway to India," it is now the U.S. warships' highway to Iraq, Saudi Arabia, Yemen, Pakistan, Afghanistan, Iran, and Somalia. ${ }^{387}$ These countries are all critical to current United States armed conflicts or to the so-called war against terrorism, or both. ${ }^{388}$ Egypt allows United States warships to cut the

American foreign policy in the Bush administration. American national interest was defined as being well-served in terms of combating Islamic terrorist extremism if the region's authoritarian and anti-democratic regimes were expunged and substituted with moderate pro-western regimes. The difficulty with regime change and transition in the region, however, has been that electorates are opting for Islamist parties and movements in the process. These movements, albeit mostly moderate, articulate a concept of political reform from within an alternate framework to the secular West. Convergence is unlikely, but accommodation is possible." (emphasis added)).

385 For fiscal year 2014, the total amount of aid was $\$ 1.3$ billion. See Background Briefing en Route to Cairo, Egypt, U.S. DEP'T STATE (June 21, 2014), http://www.state.gov/r/pa/prs/ps/2014/06/228225.htm [http://perma.cc/CE8P-RHXF]. Approximately, $\$ 575$ million had already been delivered, but approximately $\$ 75$ million had been held back. See id.

386 See David D. Kirkpatrick et al., How American Hopes for a Deal Were Undercut, N.Y. TiMES (Aug. 17, 2014), http://www.nytimes.com/2013/08/18/world/middleeast/ pressure-by-us-failed-to-sway-egypts-leaders.html?pagewanted=all\&_r $=0 \quad$ [http:// perma.cc/NYL4-JDDU]; Paul R. Williams \& Colleen Popken, U.S. Foreign Policy and the Arab Spring: Ten Short Term Lessons Learned, 41 DENV. J. INT'L L. \& PoL'Y 47, 47 (2012).

387 Afghanistan, of course, is landlocked, but the nearest port is in Pakistan through which the United States has sent most of its heavy equipment and other materiel for Afghanistan. See Jim Michaels, U.S. Military Needs Egypt for Access to Critical Area, USA TODAY (Aug. 17, 2013), http://www.usatoday.com/story/news/world/2013/08/17/ egypt-morsi-obama-hagel-gulf-heritage-brookings/2665903/ [http://perma.cc/JLE2W8EA] (explaining the geographical importance of the Suez Canal to the U.S.).

388 For a map of the Middle East illustrating the importance of free passage through the Suez Canal, see Perry-Castañeda Library Map Collection: Middle East Maps, U. TEX. LIBR., http://www.lib.utexas.edu/maps/middle_east.html [https://perma.cc/E8CH-X8G2] (last visited Oct. 25, 2015). 
line of vessels waiting to pass through the Canal. ${ }^{389}$ Furthermore, Egypt's strategic location makes it part of an ideal United States air highway to all these countries. Lastly, Egypt is one of only two Arab countries to have signed a peace treaty with Israel, and, as the most populous Arab state and a next-door neighbor, is critical to Israeli security. ${ }^{390}$

The United States' tepidly protesting the planned coup d'état and ultimately ratifying it can be explained in part by these interests. Immediately after the coup on July 3, 2013, President Obama refused to characterize the military takeover as a "coup," 391 and refused to stop the $\$ 1.5$ billion in aid to Egypt as federal law would otherwise have required. ${ }^{392}$ His response to the military overthrowing Egypt's first freely and fairly elected president was to suspend delivery of four F-16 fighter jets. ${ }^{393}$ Even that suspension was reversed less than ten days after the coup. ${ }^{394}$ Only months later did the Obama administration put a "temporary freeze" on some armaments scheduled for delivery to Egypt. ${ }^{395}$ The administration

389 Thom Shanker \& Eric Schmitt, Ties with Egypt Army Constrain Washington, N.Y. TIMES (Aug. 16, 2013), http://www.nytimes.com/2013/08/17/world/middleeast/usofficials-fear-losing-an-eager-ally-in-the-egyptian-military.html [http://perma.cc/A4XN$6 \mathrm{NWY}$.

390 In testimony before Congress, a State Department official succinctly summed up U.S. interests in Egypt. See A. Elizabeth Jones, Acting Assistant Sec'y, Bureau of Near E. Affairs, Statement Before the House Foreign Affairs Committee (Oct. 29, 2013), http://www.state.gov/p/nea/rls/rm/215965.htm [http://perma.cc/7K8J-3SJ9] ("Promoting a stable and prosperous Egypt, securing regional peace and maintaining peace with Israel, and countering extremism and terrorism throughout the region. This partnership has brought the United States significant benefits: . . . easy transit through the Suez Canal; military overflights that facilitate our activities; and the counterterrorism and counter proliferation gains that come from Egypt's efforts to control its borders with Gaza and security challenge countries like Libya.").

391 Secretary of State John Kerry went so far to say that the military was "restoring democracy" in carrying out the coup. Michael Gordon \& Kareem Fahim, Kerry Says Egypt's Military Was 'Restoring Democracy' in Ousting Morsi, N.Y. Times (Aug. 2, 2013), http:/www.nytimes.com/2013/08/02/world/middleeast/egypt-warns-morsi-supp orters-to-end-protests.html [http://perma.cc/RB9P-EF4B]; Kirkpatrick, supra note 283.

392 See Background Briefing en Route to Cairo, Egypt, supra note 385.

393 Kirkpatrick et al., supra note 386.

394 Richard Spencer, U.S. Still Planning to Send F16 Jets to Egypt, DAILY TELEGRAPH (July 12, 2013), http://www.telegraph.co.uk/news/worldnews/africaandindianocean/ egypt/10172850/US-still-planning-to-send-F16-jets-to-Egypt.html [http://perma.cc/ U6UG-H4R4].

395 See Michael Gordon \& Mark Landler, In Crackdown Response, U.S. Temporarily Freezes Some Arms to Egypt, N.Y. TimES (Oct. 9, 2013), http://www.nytimes.com/2013/ 
subsequently lifted the freeze on most of the armaments. ${ }^{396}$ Primarily Republican members of Congress but Democratic members as well criticized the President even for imposing these sanctions on the Egyptian military. ${ }^{397}$

In two separate incidents in July 2013, the Egyptian military killed more than sixty peaceful protesters in the first incident and more than seventy peaceful protesters in the second, yet the Obama administration did not suspend aid. ${ }^{398}$ Following the Egyptian military's Tiananmen-Square-type attack against Muslim Brotherhood protesters on August 14, 2013, the Obama administration attempted to cool the increased violence, but the

10/10/world/middleeast/obama-military-aid-to-egypt.html?pagewanted=all [http:// perma.cc/8CT3-9ENU] ("To signal its displeasure at the Egyptian military's bloody crackdown on the Muslim Brotherhood, officials said, the United States would withhold the delivery of several big-ticket items, including Apache attack helicopters, Harpoon missiles, M1-A1 tank parts and F-16 warplanes, as well as \$260 million for the general Egyptian budget."); U.S. Unlocks Military Aid to Egypt, Backing President Sisi, BBC (June 22, 2014), http://www.bbc.com/news/world-middle-east-27961933 [http://perma.cc/ TN43-JST6] ("But in a sign of how the administration is balancing its interests, senior officials said the United States would continue aid for counter- terrorism programs as well as for Egypt's efforts to protect its borders and secure Sinai, which has become a haven for extremists."). Hardly making a reference to Egypt's human rights violations, Secretary of State John Kerry addressed in March 2015 an economic conference seeking to assist the el-Sisi government and Egypt. Sarah El Deeb \& Brian Rohan, Egypt Rakes in Promises of Billions in Gulf Aid, YAHOO NEws! (Mar. 13, 2015), http://news.yahoo.com/egypts-elsissi-inaugurates-three-day-economic-conference-143327308--finance.html [http:// perma.cc/9RQL-4JGJ] (reporting Kerry's support for continuing aid to Egypt).

396 Peter Baker, Obama Removes Weapon Freeze Against Egypt, N.Y. Times (Mar. 31, 2015), http://www.nytimes.com/2015/04/01/world/middleeast/obama-lifts-armsfreeze-against-egypt.html [http://perma.cc/3P9K-XV97].

397 U.S. Congress Slams Military Aid Cuts to Egypt, MEMO Middle E. Monitor (Oct. 30, 2013), https://www.middleeastmonitor.com/news/americas/8052-us-congressslams-military-aid-cuts-to-egypt [http://perma.cc/9QY3-5MZY]. On the other hand, standing apart from the Republican leadership, Sens. John McCain and Lindsey Graham sharply criticized the Obama administration for failing to cut off some substantial aid to Egypt. John McCain \& Lindsey Graham, Opinion, Cut Off Aid to Egypt, WASH. Post (July 12, 2013), http://www.washingtonpost.com/opinions/john-mccain-and-lindseygraham-cut-off-aid-to-egypt/2013/07/12/5850a1f4-eb19-11e2-a301-ea5a8116d211_story .html [http://perma.cc/88LE-3TX7] (arguing for the termination of all aid to Egypt until its government makes reforms).

398 Kareem Fehim, Crackdown in Egypt Kills Islamists as They Protest, N.Y. TIMES (July 27, 2013), http://www.nytimes.com/2013/07/28/world/middleeast/egypt.html [http://perma.cc/Q4CW-T4ZS] (noting that "[t]he tactics-many were killed [by the Egyptian security forces] with gunshot wounds to the head or the chest-suggested that Egypt's security services felt no need to show any restraint"). 
Egyptian military regime, "coldly calculated," that the Americans would not stop the aid, and ignored the Americans efforts. ${ }^{399}$ The Egyptian generals calculated correctly: President Obama suspended a joint training exercise, but not the $\$ 1.5$ billion in assistance. ${ }^{400}$

For Fiscal Year 2014, the Obama Administration informed Congress of its intent to spend (give to Egypt) all $\$ 1.3$ billion in appropriated Egyptian military aid and did so in two $\$ 650$ million tranches in April 2014 and January 2015, respectively, ${ }^{401}$ and in March 2015 announced the delivery of withheld weapons, ${ }^{402}$

399 Kirkpatrick et al., supra note 386 ("All of the efforts of the United States government, all the cajoling, the veiled threats, the high-level envoys from Washington and the 17 personal phone calls by Defense Secretary Chuck Hagel, failed to forestall the worst political bloodletting in modern Egyptian history. The generals in Cairo felt free to ignore the Americans first on the prisoner release and then on the statement, in a cold-eyed calculation that they would not pay a significant cost-a conclusion bolstered when President Obama responded by canceling a joint military exercise but not $\$ 1.5$ billion in annual aid."); see also Kirkpatrick, supra note 283 and accompanying text (detailing the Egyptian military's August 14, 2013, attack).

400 Kirkpatrick et al., supra note 386 ("[T]he Israelis, Saudis and other Arab allies have lobbied [President Obama] to go easy on the generals in the interest of thwarting what they see as the larger and more insidious Islamist threat."); Steve Kenny, Egypt: U.S. to Deliver Helicopters, N.Y. TIMES (Apr. 23, 2014), http://www.nytimes.com/2014/04/23/ world/middleeast/egypt-us-to-deliver-helicopters.html [http://perma.cc/8NRR-K4MG]. Secretary of State John Kerry also informed the Egyptian government that it was meeting its commitments under the Camp David Accords, thereby entitling Egypt to additional aid. Id. It is submitted, however, that long-term Israeli security would be better served by having an Islamic democratic regime than a secular military one that has violently put down the democratic Islamic movement, sparking increased terrorism. TAHRIR INST. FOR Middle E. Policy, Egypt Security Watch - Monthly Briefing: February 2015, at 1 (2015), http://timep.org/esw/articles-analysis/egypt-security-watch-monthly-briefing-5february-2015/ [http://perma.cc/8LZS-CQMM] (noting the increased number of terror attacks in Egypt). The United States also decided to lift its suspended delivery of ten Apache Attack helicopters to Egypt. Sandra Maler, U.S. to Deliver 10 Apache Helicopters to Egypt - Pentagon, YAHOO! NEWS (Sept. 20, 2014), http://news.yahoo.com/u-s-deliver10-apache-helicopters-egypt-pentagon-024754535--finance.html [https://perma.cc/ 4WZV-RY39].

401 SHARP, supra note 194, at 3. Senator Leahy had initially blocked the April 2014 $\$ 650$ million tranche, but, according to Secretary of State Kerry, all but $\$ 78$ million of that tranche was released by June 2014. James Rosen, Kerry Seeks to Nudge Egypt's New President Toward Reforms on Cairo Visit, Fox News (June 22, 2014), http://www.foxnews.com/politics/2014/06/22/kerry-seeks-to-nudge-egypt-new-president -toward-reforms-on-cairo-visit/ [http://perma.cc/G3LP-39E7] (reporting on the amount of aid to Egypt and the tranche).

402 David D. Kirkpatrick, U.S. to Decide Soon on Restoring Military Aid to Egypt, N.Y. TIMES (Mar. 14, 2015), http://www.nytimes.com/2015/03/15/world/middleeast/ kerry-promises-decisions-soon-on-iran-deal-and-restoration-of-military-aid-to- 
including delivery of F-16 aircraft, Harpoon missiles, and M1A1 Abram tanks. ${ }^{403}$

Furthermore, within a week of the coup, Saudi Arabia, together with Kuwait and the United Arab Emirates, pledged to give the Egyptian military regime twelve billion dollars, "dwarf[ing]" that of the United States ( $\$ 1.5$ billion) and the EU ( $\$ 1.3$ billion) combined..$^{404}$ These Middle East regional players, all of which are authoritarian regimes with abysmal human rights records, ${ }^{405}$ have

egypt.html [http://perma.cc/CB7U-VT5Y] (noting also that the United States was withholding \$700 million in military aid from Egypt but subsequently released it).

403 Peter Baker, Obama Removes Weapons Freeze Against Egypt, N.Y. TiMEs (Mar. 31, 2015), http://www.nytimes.com/2015/04/01/world/middleeast/obama-lifts-armsfreeze-against-egypt.html [http://perma.cc/K8Z3-EU7V] (asserting the White House did not claim "credible progress"). Congress has enacted legislation requiring that Egypt fulfill human rights and democratic conditions before receiving aid, but has also granted the Secretary of State the right to waive such conditions in the interest of U.S. security. SHARP, supra note 194, at 4 (giving the Secretary of State the right to bypass). President Obama, however, did not claim that Egypt "had made "credible progress' toward democracy[,]" citing "the interest in U.S. national security." Baker, supra. The Obama administration has criticized the Egyptian government, but is essentially fully funding it. David D. Kirkpatrick, Obama Administration Criticizes Egypt in Report to Congress, N.Y. TIMES (June 7, 2015), http://www.nytimes.com/2015/06/08/world/ middleeast/obama-administration-criticizes-egypt-in-report-to-congress.html [http:// perma.cc/V5WP-NNA4]; SHARP, supra note 193, at 26 ("For FY2016, both House and Senate draft foreign operations appropriations bills (H.R. 2772 and S. 1725 respectively) would provide the President's full request for Egypt of up to $\$ 1.3$ billion in FMF [Foreign Military Financing] and $\$ 150$ million in ESF [Economic Support Funds].”).

404 Rod Norland, Saudi Arabia Promises to Aid Egypt's Regime, N.Y. TimEs (Aug. 19, 2013), http://www.nytimes.com/2013/08/20/world/middleeast/saudi-arabia-vows-toback-egypts-rulers.html [http://perma.cc/MF6L-LZRF]. The package consists of $\$ 5$ billion from Saudi Arabia, \$4 billion from Kuwait, and \$3 billion from UAE. Id. Israel also supported the Egyptian military regime. Id. "Saudi Arabia, which itself is a close ally of Washington, has not only undermined Western efforts to press for compromise, but has also revealed diminished U.S. influence across the Arab world. The United States and Europe have been unable to convince Cairo-or to persuade Riyadh to press the generals toward moderation." Id. " The Saudi monarchy is absolutely afraid of an Islamist-based democracy movement,' said Amanda E. Rogers, a lecturer in Arabic at Emory University in Atlanta and contributor to Muftah, a blog about the Middle East and North Africa." Id.

405 See, e.g., U.S. DeP'T State, Country Reports on Human Rights Practices for 2013: UNITED ARAB EMIRATES (2013) ("The three most significant human rights problems were citizens' inability to change their government; limitations on citizens' civil liberties (including the freedoms of speech, press, assembly, association, and internet use); and arbitrary arrests, incommunicado detentions, and lengthy pretrial detentions."); U.S. DEP'T State, Country Reports on Human Rights Practices for 2013: Bahrain (2013) ("The most serious human rights problems included citizens' inability to change their government peacefully; arrest and detention of protesters on vague charges, in some cases 
reduced the ability of the West - assuming it had the political will to have softened the military's repression of the Muslim Brotherhood. ${ }^{406}$

The coup thus placed the Obama administration on the horns of a dilemma: "[A.] [R]isk a partnership that been the bedrock of Middle East peace for [thirty-five] years or [B.] [S]tand by while longtime allies try to hold on to power by mowing down opponents." 407 The administration with the Republican leadership's implicit agreement has chosen option "B." 408

\section{Conclusion}

The Ottoman Empire's weakness led to its downfall and to the West's colonization of Muslim countries. The colonization of Egypt by Britain led to a tradition of autocratic secular military

leading to their torture in detention; and lack of due process in trials of political and human rights activists, medical personnel, teachers, and students, with some trials resulting in harsh sentences."); Qatar UN Review: Crucial Reforms Needed to Protect Women and Migrant Workers, AMNESTY INT'L (May 6, 2014), http://www.amnesty.ca/news/newsreleases/qatar-un-review-crucial-reforms-needed-to-protect-women-and-migrant-workers [http://perma.cc/2DZG-EFWD] (discussing Qatar's lack of human rights protections for migrant workers, domestic violence victims, and persons tortured in detention centers); Annual Report: Kuwait 2013, AMNESTY INT'L (May 23, 2013), http://www.amnestyusa.org/research/reports/annual-report-kuwait-2013 [http://perma.cc/ 5A55-JDJH] (discussing exploitation of migration workers and Kuwait's use of excessive force against demonstrators); FREEDOM HoUSE, supra note 167 (rating the four small Gulf States "not free," except for Kuwait, which earned a "part free" rating). Saudi Arabia was among the ten worst countries in the world for human rights. Id.

406 Vladimir Putin visited Egypt for a two-day visit on February 9, 2015, to send a message to the United States that "their foreign policies are not to be dictated by others." Patrick Kingsley, Vladimir Putin's Egypt Visit Sends Message to U.S., GuARDIAN (Feb. 9, 2015), http://www.theguardian.com/world/2015/feb/09/vladimir-putin-egypt-visitmessage-us-russia?CMP=share_btn_link [http://perma.cc/FX3J-CGD9].

407 Kirkpatrick et al., supra note 386; see also Emad Mekay, Military Oppression Sows Seeds of Violence in Egypt, INT'L B. Ass'N (2013), http://www.ibanet.org/Article/Detail.aspx?ArticleUid=5fc6c631-a517-4d67-b30e-ca97a9 4c1b5b [http://perma.cc/GB3E-SNTE] ("Al-Qaeda's ideology of violence as the only means of change has now received a new lease of life."); Jared Maslin, Cairo Citizens Caught Between Isis Violence and Abdel Fatah al-Sisi's Draconian Security Crackdowns, GUARDIAN (Aug. 22, 2015), http://www.theguardian.com/world/2015/aug/23/cairocitizens-isis-violence-sisi-draconian-security-crackdowns [http://perma.cc/9J6E-TEJW] (noting a "culture of fear growing in Egypt"); Kareem Fahim \& David D. Kirkpatrick, Jihadist Attacks on Egypt Grow Fiercer, N.Y. TIMES (July 1, 2015), http:// www.nytimes.com/2015/07/02/world/middleeast/sinai-isis-attack.html?_r=0 [http:// perma.cc/PN7U-RBT6].

408 Kirkpatrick et al., supra note 386. 
leaders including Muhammed Ali, Gamal Abdul Nasser, Anwar AlSadat, Hosni Mubarak, and Abdul Fattah el-Sisi. That colonization, its aftermath, and Kemal Ataturk's related aggressive secularism gave rise to an Islamic fundamentalist reaction, creating Hasan al Banna, his Muslim Brotherhood and his progeny: Sayyid al-Qutb, Ayman al-Zawahiri, and Osama bin Laden, and their movements, including al-Qaeda and arguably ISIS. ${ }^{409}$ Consequently, we in the West have to be particularly sensitive to policies and practices that perpetuate this vicious cycle.

Unfortunately, the United States began to take on the face of a Middle East colonial power at the end of World War II. U.S. policy concentrated on continuing the supply of oil and containing communism. With a few exceptions, ${ }^{410}$ the United States displayed little concern for the human rights of Arab and Muslim people or for the growth of democratic movements and institutions in the Arab and Islamic worlds. ${ }^{411}$

Ireland was Britain's first colony. The Irish suffered discrimination at the hands of the British and British settlers for centuries. The Irish have a saying, "The British never remember, the Irish never forget." ${ }^{12}$ Americans tend to forget our supporting repressive regimes in the Middle East for decades, our thwarting democratic movements in that region, and in particular our giving

\footnotetext{
409 ISIS does trace itself to Muhammed ibn Abd ab-Wahhab, and his "austere interpretation of Islam," known as Wahhabism, coming from 18th century Saudi Arabia. David D. Kirkpatrick, Extremist Group's Harsh Brand of Islam Has Roots in Austere Saudi Creed, N.Y. TIMES (Sept. 25, 2014), http://www.nytimes.com/2014/09/25/world/ middleeast/isis-abu-bakr-baghdadi-caliph-wahhabi.html [http://perma.cc/MSP7-F6YS]. The British support of Abdul Aziz ibn-Saud during World War I, however, helped him emerge as the ruler of Saudi Arabia, and with him, Wahhabism. Saudi Arabia's oil wealth has helped Wahhabism spread around the globe. ANDERSON, supra note 182 (describing Abdul Aziz ibn-Saud's rise to power).

410 Some exceptions include the United States opposing the British and French 1956 war against Egypt's nationalizing the Suez Canal and the 1999 NATO intervention in Kosovo on behalf of the Albanian Kosovars. See, e.g., PeEvers, supra note 84; Kosovo Conflict: Balkan History, ENCYCLOPAEDIA BRITANNICA, http://www.britannica.com/event/ Kosovo-conflict [http://perma.cc/TUB2-PPR2] (last visited May 1, 2015).

411 See Mark P. Lagon, Promoting Human Rights: Is U.S. Consistency Desirable or Possible? A Markets and Democracy Brief, Council On Foreign Rel. (Oct. 2011), http:// www.cfr.org/human-rights/promoting-human-rights-us-consistency-desirable-possible/p 26228 [http://perma.cc/M4FP-UFTB].

412 Daniel Shriver, Where and When in Political Life Is Justice Served by Forgiveness, in Burying the Past: Making Peace and Doing Justice After Civil Conflict 25, 31 (Nigel Biggar ed., 2003).
} 
Mubarak billions of dollars while he ruled Egypt by decree and routinely tortured political opponents including Muslim Brotherhood members. Arabs and Muslims throughout the world generally never forget these things. Certainly, they are not forgotten by Islamic fundamentalists. ${ }^{413}$

Because the West and Russia have exploited Muslim peoples and contributed to the rise both of autocratic leaders and extreme fundamentalists, the West and Russia have a moral, if not strictly legal obligation not only to help Muslim countries economically, but also to further a peaceful and democratic resolution of the issues that such Western and Russian policies and practices brought about. Achieving this latter objective requires greater resort to tough diplomacy than to military force. Ratifying the Egyptian military coup constitutes a failure of the United States and the West in general to take a peaceful, non-violent path towards resolving the challenge of Islamic terrorism. Denying Egypt's Islamic fundamentalists their fairly won presidential election and parliamentary elections ${ }^{414}$ feeds into the propaganda of the extremists, silences moderates who wish to follow the rule of law, and strengthens those espousing the hardest line toward the West. ${ }^{415}$ By implicitly endorsing the Egyptian military's repression of generally peaceful protesters and political opponents, we also make more likely revenge attacks against the 'far enemy' - the United States - by jihadists outraged by the Egyptian military's onslaught

413 Perhaps not coincidentally, the West and Russia have been responsible for more than millennia-old discrimination against Jews, ultimately resulting in the Holocaust. Under the same reasoning, the West and Russia bear a moral, if not legal responsibility for resolving the Israeli-Palestinian crisis.

414 See Bassiouni, Egypt Update Number 16, supra note 223 (criticizing the election law as being biased in favor of political parties' candidates). But see Aziz, supra note 198, at 4 (criticizing the election laws but noting that "Egyptians viewed with suspicion the Supreme Constitutional Court's June 12, 2012, ruling calling for the dissolution of a Muslim dominated parliament").

415 Mara Revkin, Brotherly Love-Why Sisi's Win Is Good for Al Qaeda, ForEIGN AfF. (May 29, 2014), https://www.foreignaffairs.com/articles/egypt/2014-05-29/brotherly-love [https://perma.cc/3ZEG-PDBS]; The Egyptian Coup, the United States, and the Threat of Terrorism, INT'L L. PROF BLOG (Sept. 11, 2013), http://lawprofessors. typepad.com/international_law/2013/09/guest-editorial-.html [http://perma.cc/QMK329YJ] (arguing that the United States implicitly supporting the coup has fashioned her against radical Islam); Tom McDonnell, Letter to the Editor, U.S. Policy Toward Egypt, N.Y. TIMES (May 5, 2014), http://www.nytimes.com/2014/05/06/opinion/us-policytoward-egypt.html [http://perma.cc/D5YT-YLE7] (criticizing U.S. policy toward Egypt). 
against the Muslim Brotherhood. ${ }^{416}$ Furthermore, such endorsement of the coup and its aftermath makes President Obama's call for democracy and for Muslims to stop ISIS and al-Qaeda extremists ${ }^{417}$ appear hypocritical. ${ }^{418}$

Admittedly, the Egyptian case has been challenging. The Muslim Brotherhood is an illiberal organization which espouses many views most in the West abhor, advocating a strict interpretation of sharia law, practicing de jure discrimination against women and the LGBT community, ${ }^{419}$ preaching intolerance of other religions, and showing hostility to our ally, Israel. ${ }^{420}$ Morsi

416 Ayman al-Zawahiri Says U.S. Behind Coup That Ousted Morsi, GuARDIAN (Aug. 3, 2013), http://www.theguardian.com/world/2013/aug/03/ayman-zawahiri-coupmohamed-morsi [http://perma.cc/W99W-2LJN].

417 President Barack Obama, Remarks by President Obama in Address to the United Nations General Assembly (Sept. 24, 2014), https:/www.whitehouse.gov/the-press-offic e/2014/09/24/remarks-president-obama-address-united-nations-general-assembly [https:// perma.cc/W8LN-YGWZ].

418 President Obama's recent call for "more democracy" as the chief counter to terrorism is unquestionably correct, but his call appears hypocritical given the actions of the United States. See President Barack Obama, Remarks in Closing of the Summit on Countering Violent Extremism (Feb. 18, 2015), https://www.whitehouse.gov/the-press-off ice/2015/02/18/remarks-president-closing-summit-countering-violent-extremism [https:// perma.cc/XHH7-LXVK] ("When governments oppress their people, deny human rights, stifle dissent or marginalize ethnic and religious groups, favor certain religious groups over others, it sows the seeds of extremism and violence."). That is precisely what the Egypt military has done, with the implicit ratification by the United States.

419 See Shadi Hamid, The Brotherhood Will Be Back, N.Y. TimES (May 23, 2014), http://www.nytimes.com/2014/05/24/opinion/more-democratic-less-liberal.html [http:// perma.cc/26J3-BTMM] (arguing that in a religious society like Egypt, democracy and illiberalism go together). But conditions for the LGBT community may not be that much better under the military. See Patrick Kingsley, Egypt Jails Eight Men After "Gay Marriage” Ceremony on Nile, GuARDIAN (Nov. 3, 2014), http://www.theguardian.com/ world/2014/nov/03/egypt-jails-eight-men-gay-marriage-ceremony-nile?CMP=ema_565 [http://perma.cc/SFB6-25CE] (reporting on Egypt's treatment of LGBT peoples); ICJ Welcomes General Assembly's Third Committee's Adoption of Resolution on Extrajudicial, Summary or Arbitrary Executions, INT'L COMMISSION JURISTS (Nov. 21, 2014), http://www.icj.org/icj-welcomes-general-assemblys-third-committees-adoptionof-resolution-on-extrajudicial-summary-or-arbitrary-executions/ [http://perma.cc/L8UMBPYQ] (noting that the GA resolution "urges state to investigate killings based on discriminatory grounds including killings that target people based on their sexual orientation or gender identity" and that Egypt proposed an amendment to remove the language referring to LGBT persons).

420 The Morsi regime, however, abided by the Camp David Accords. Cf. David M. Faris, Deep State, Deep Crisis: Egypt and American Policy, Middle E. Pol'y Council, Winter 2013, at 99, http://www.mepc.org/journal/middle-east-policy-archives/deep-statedeep-crisis-egypt-and-american-policy [https://perma.cc/T5RJ-4JUX] (stating that Egypt 
and his Parliament were making a grab for power. There were massive protests against his rule by the secularists with whom the West understandably has greater sympathy.

Yet implicitly backing the military coup undermined one of the most fundamental values of all: the rule of law and the peaceful electoral process, the minimum requirements for a legitimate democracy. It teaches Islamic fundamentalists that they may achieve their aims only by violence, not by the ballot box. ${ }^{421}$ The United States' failure reflects a fundamental misunderstanding of how historical, political, legal, and religious forces created the perfect storm that contributed both to $9 / 11$ and to the current struggle with Islamic terrorism.

Granted, the United States has critical foreign policy interests in maintaining a close relationship with Egypt. On the other hand, the United States has a critical foreign policy interest in quelling international terrorism. ${ }^{422}$ Propping up dictatorial regimes in the Middle East closes off peaceful avenues of protest, forcing people wishing to change the regime's policies to go underground, to join or support what the regime will almost certainly label terrorist organizations. By discriminating against Muslim fundamentalists and implicitly ratifying the illegal use of force against them, United States "play[s] into the hands of the extremists," 423 ultimately compelling the United States to resort to military counter-terrorism.

At a minimum the Obama administration should have cut off military aid, ${ }^{424}$ sought a U.N. Security Council Resolution

had adhered to the Accords).

421 See Mekay, supra note 407 ("Al-Qaeda's ideology of violence as the only means of change has now received a new lease of life."); Revkin, supra note 415 ("Egypt has seen a dramatic increase in domestic terrorism with over 300 documented attacks since July 2013.”); TAHRIR InST. FOR MidDle E. PoliCY, supra note 400 (noting increased terrorist attacks in Egypt).

422 If Egypt is the keystone to peace in the Middle East, and if we assume Egypt will turn away from the United States without the annual $\$ 1.3$ billion in military aid, which the United States has provided for more than thirty years, not to mention providing military equipment and training for Egyptian officers in that time, then those payments themselves are a thin reed on which to base so-called Middle East peace and other critical interests. path).

423 Revkin, supra note 415 (permitting jihadist to demonstrate that violence is the only

424 On the other hand, the administration might have increased earmarked economic aid, given the dire state of the Egyptian economy, consistent with the purpose of the Special International Security Act of 1979 "in order to promote the economic stability and development of [Egypt] and to support the peace process in the Middle East." 22 U.S.C. 
condemning the Egyptian government's use of excessive force against those protesting the takeover, and threatened both a travel ban on the coup's leaders and a world boycott of the sale to Egypt of military equipment and supplies.

Despite the ever increasing polarized politics here, Americans have deep respect for democracy, the peaceful electoral process, the right to protest, to free speech, to fair trial and to other fundamental human rights. Neither the American public nor the American court system would ever countenance some judges' dissolution of the United States Congress, or of the authorities' shooting to kill innocent protesters, torturing political opponents, banning the party that won the last presidential election, and imprisoning all its leaders, not to mention overthrowing the President, throwing him in jail in a desert prison, and charging him with a capital offense.

Our best counter-terrorism policy and practice is to foster democratic institutions, the rule of law, and international human rights in the Arab and Muslim worlds. ${ }^{425}$ Implicitly ratifying the coup and the Egyptian military's extreme violence in putting down protest eviscerates that policy. ${ }^{426}$ If we are serious about reducing

§ 3401(b)(3) (2015). But see Whither American Aid to Egypt, AM. U. CAIRo (Sept. 23, 2012), http://www.aucegypt.edu/GAPP/casar/Pages/Whither-Economic-Aid-to-Egypt. aspx [http://perma.cc/EBC2-FEH6] (discussing U.S. economic aid to Egypt and how it has varied from the originally set ratio and quoting Special International Security Assistance Act of 1979, Pub. L. No. 96-35); Agreement on the Framework for Peace in the Middle East, supra note 194 (setting forth the ratio of aid the U.S. would give to Egypt and Israel). In addition, such economic aid should also be sufficiently high (a) to pay for the privilege of allowing U.S. warships to cut the line of ships waiting to pass through the Suez Canal and (b) to comply with U.S. obligations under the Camp David accords. See Whither American Aid to Egypt, supra. One could argue that given the $\$ 12$ billion that Saudi Arabia, U.A.E., and Kuwait gave Egypt, cutting off aid would not change the Egyptian leadership's policies. Id. On the other hand, such a cut off in military aid would unambiguously send a message of support for democratic institutions throughout the Muslim world.

425 Also fundamental is resolving the Israeli-Palestinian dispute. See MCDonNELL, supra note 7 , at $14-16$.

426 See supra note 418 and accompanying text (noting how the perceived hypocritical nature of the administration's policy and statements). One study showed that negative attitudes towards the United States, after the Egyptian coup, predominated by ten to fifteen times more than positive attitudes. Amaney A. Jamal et al., Anti-Americanism in Arabic Twitter Discourses Is Driven by Perceptions of U.S. Impingement in the Region, LSE US CENTRE (Mar. 19, 2015), http://blogs.lse.ac.uk/usappblog/2015/03/19/anti-americanismin-arabic-twitter-discourses-is-driven-by-perceptions-of-u-s-impingement-in-the-region/ [http://perma.cc/T3Q4-JN7D] (describing change in negative posts towards the United States after the Egyptian coup). 
the threat of Islamic terrorism, we, with our European and other allies, have to stop applying a double standard to Arabs and Muslims, including their fundamentalists, and, instead, have to recognize and affirmatively address the suffering all peoples in the Middle East have experienced. 